\title{
Still Digging: Advances and Perspectives in the Study of the Diversity of Several Sedentarian Annelid Families
}

\author{
Maël Grosse ${ }^{1, *(\mathbb{C}}$, Anna Zhadan ${ }^{2}\left(\mathbb{D}\right.$, Joachim Langeneck ${ }^{3}$, Dieter Fiege ${ }^{4}$ and Alejandro Martínez ${ }^{5}$ \\ 1 Tjärnö Marine Laboratory, Department of Marine Sciences, University of Gothenburg, \\ SE 45296 Strömstad, Sweden \\ 2 N.A. Pertsov White Sea Biological Station, Biological Faculty, M.V. Lomonosov Moscow State University, \\ 119234 Moscow, Russia; azhadan@wsbs-msu.ru \\ 3 Department of Biology, University of Pisa, 56126 Pisa, Italy; jlangeneck@biologia.unipi.it \\ 4 Sektion Marine Evertebraten II, Forschungsinstitut und Naturmuseum Senckenberg, \\ 60325 Frankfurt, Germany; dieter.fiege@senckenberg.de \\ 5 Molecular Ecology Group (MEG), Water Research Institute (IRSA), National Research Council of Italy (CNR), \\ 28922 Pallanza, Italy; alejandro.martinezgarcia@cnr.it \\ * Correspondence: maelgrosse@gmail.com
}

check for updates

Citation: Grosse, M.; Zhadan, A.; Langeneck, J.; Fiege, D.; Martínez, A. Still Digging: Advances and Perspectives in the Study of the Diversity of Several Sedentarian Annelid Families. Diversity 2021, 13, 132. https://doi.org/10.3390/ d13030132

Academic Editors: Michael Wink Pat Hutchings and Maria Capa

Received: 14 January 2021

Accepted: 22 February 2021

Published: 18 March 2021

Publisher's Note: MDPI stays neutral with regard to jurisdictional claims in published maps and institutional affiliations.

Copyright: (c) 2021 by the authors. Licensee MDPI, Basel, Switzerland. This article is an open access article distributed under the terms and conditions of the Creative Commons Attribution (CC BY) license (https:/ / creativecommons.org/licenses/by/ $4.0 /)$.

\begin{abstract}
Sedentarian annelids are a diverse and heterogeneous group of marine worms representing more than 8600 species gathered in ca. 43 families. The attention brought to these organisms is unevenly distributed among these families, and the knowledge about them sometimes scarce. We review here the current knowledge about the families Acrocirridae, Cirratulidae (including Ctenodrilidae), Cossuridae, Longosomatidae, Paraonidae, and Sternaspidae in terms of biodiversity as well as the evolution of the taxonomy and systematics of each group. We present the challenges faced when studying these organisms and compare methodologies across groups and perspectives in future research.
\end{abstract}

Keywords: Annelida; systematics; biodiversity; taxonomy; Acrocirridae; Cirratulidae; Sternaspidae; Longosomatidae; Paraonidae; Cossuridae

\section{Introduction}

Sedentarian annelids represent a morphologically heterogeneous clade of worms comprising ca. 43 families and more than 8600 species [1]. Although the relationships among annelids are far from being understood, different independent sources of evidence suggest that the clades Cirratulida, Sabellida, and Spionida might represent the sister clade of the remaining Sedentaria, which at least include the orders Terebellida, Arenicolida, Opheliida, Capitellida, Echiura, and Clitellata [2-4]. However, relationships among these groups remain to be investiged using extensive datasets with both molecular and morphological characters and a larger taxon sampling. Within this incomplete picture, there are several lineages whose relationships with the remaining Sedentaria remain particularly obscure, including Cossuridae Day, 1963 [5], Paraonidae Cerruti, 1909 [6], Siboglinidae Caullery, 1914 [7], Hrabeiella Pizl, 1984 [8], Aeolosoma Ehrenberg, 1828 [9], Potamodrilus Lastochkin, 1935 [10], Scalibregmatidae Malmgren, 1867 [11], and Travisiidae Hartmann-Schröder, 1971 [12], among many others. Many recent studies have reviewed the current knowledge of several of these sedentarian lineages [13-16], including several articles within this issue [17-21], while others have received less attention (See [4]). In this article we focus on the cirratuliform families Acrocirridae Banse, 1969 [22], Cirratulidae Ryckholt, 1851 [23], and Sternaspidae Carus, 1863 [24], as well as the families Longosomatidae Hartman, 1944 [25], Paraonidae, and Cossuridae, with the goal of providing an updated overview of our current knowledge on their diversity and systematics.

Acrocirridae, Cirratulidae, and Sternaspidae have been placed within the Cirratuliformia along with Flabelligeridae Saint-Joseph, 1984 [26] and Fauveliopsidae Hartman, 
1971 [27]. Most families within this clade consist of worms with few external morphological characters, typically thin and elongated, with little body regionalization and reduced parapodia $[28,29]$. They often exhibit some kind of more or less filamentous branchiae and/or tentacles. Those are sometimes represented by a few, segmentally arranged long filamentous branchiae, as in Acrocirridae, and other times consisting of numerous tentacles, as in Cirratulidae. However, there are exceptions, such as Sternaspidae and Fauveliopsidae, which are represented by species with thick, short bodies lacking prostomial appendages [30,31]. The clade mostly consists of benthic organisms, present mostly in sediments from the intertidal area to the abyssal plains. However, some Cirratulidae are hard-bottom dwellers and a few species of acrocirrids and flabelligerids have conquered the pelagic realm, exhibiting staggering divergent morphologies [32,33]. Among the cirratuliform families described in detail within this article, the most species-rich is Cirratulidae, with approximately 355 described species and 16 genera; followed by Acrocirridae, with 45 species and 10 genera; and Sternaspidae, with four genera and 43 species [1].

The Cossuridae and the Paraonidae are small, threadlike animals [29,34]. The Cossuridae bear a characteristic unpaired branchial filament attached to the dorsal side of one of the anterior segments. Paraonids are also simple-looking, but exhibit a certain heteronomy in the body, with the anterior part wider and slightly flattened, bearing a variable number of segmentally arranged branchiae. Species in both families are benthic and nearly exclusively found in sediments of various granulometries all over the world. In terms of number of species, both families are considered relatively poor. More than 150 species among eight genera of Paraonidae are currently known [35], while only 29 species have been described for the monotypic Cossuridae [36]. These numbers are likely affected, though, by the relatively simple, conservative morphology shown in both groups that makes the identification at the species level challenging. Therefore, they are likely to increase as integrative studies, including detailed morphological analyses and inclusion of molecular data, are performed within both families. Paraonidae and Cossuridae remain unplaced in the annelid tree as analyses of different sources provide mutually exclusive hypothesis, and so far, no comprehensive analyses have been performed. Despite that, some authors have suggested an affinity of these two families with the Cirratuliformia [4]. Initially, Cossura was placed within the family Cirratulidae, until Day established the Cossuridae [5]. In a phylogenetic hypothesis based on morphological characteristics, Cossuridae was placed in the clade Scolecida as a basally branching lineage [37]. In contrast, molecular data have grouped Cossuridae with Fauveliopsidae and Paraonidae, in a clade sister to other Cirratulida [38]. A close relationship between Paraonidae and Spionidae or Orbiniidae was suggested during a series of comprehensive cladistic studies [37,39], although it seems more likely that these results were misled by the presence of shared plesiomorphic morphological characters in some of these families [40]. Analyses of DNA sequences have recovered Paraonidae nested within Cirratuliformia, somehow related to Cirratulidae and Cossuridae [41], or as the sister group of Sternaspidae [42].

Finally, Longosomatidae is a family of small, cylindrical, elongated worms, characterized by their distinct body regionalization with an enlarged anterior and posterior end, and thin, very long middle segments [43]. Longosomatidae is a small family, with eight species, all belonging to Heterospio Ehlers, 1874 [44], although many species remain undescribed. The phylogenetic affinities of this family remain controversial. Based on morphology, Longosomatidae have long been thought related to spioniform polychaetes, but they also share many morphological similarities with Cirratulidae, and COI analyses recover Longosomatidae somehow related to Cirratulidae, yet acknowledging the limitation that this marker presents for deep phylogenetic reconstruction [45].

This review follows a family-by-family approach. For the families Acrocirridae, Cirratulidae (including Ctenodrilidae), Cossuridae, Longosomatidae, Paraonidae, and Sternaspidae, we summarize our current knowledge on species diversity, systematics, morphological diversity, distribution patterns and ecological preferences. These topics have also been discussed for Fauveliopsidae in a recent review by Salazar-Vallejo et al. [46]. 
The main gaps of knowledge relative to each of these aspects and the technical and practical aspects of systematic study of these polychaetes in general are discussed along with perspectives for future research.

\section{Acrocirridae Banse, 1969}

Annelids belonging to the family Acrocirridae Banse, 1969 [22] are cryptic, yet locally abundant worms, characterized by cylindrical bodies with conspicuous falcigerous compound chaetae, and up to four pairs of segmentally arranged, filiform branchiae on the anteriormost body segments [28] (Figure 1). There are benthic and pelagic forms, inhabiting a variety of environments. Whereas this family has historically received little attention, it currently benefits from a regain of interest among marine biologists and even the general public, due to the recent discovery of several deep-sea pelagic species presenting quite peculiar morphologies [32].

\subsection{Morphology}

Acrocirridae is a morphologically rather heterogenous family, exhibiting quite a large variation in morphology and habitat across species within different clades. Important characters for species identification include the position, size, and shape of the prostomium, shape of the nuchal organs, presence of eyes, presence of head branchiae, number and shape of achaetous first segments, number of branchiae, arrangement and shape of interramal papillae, and the shape and arrangements of the chaetae.

The prostomium is usually dorsal to the peristomium and varies in size and shape between genera and species. The prostomium is rounded and well developed in species of Acrocirrus Grube, 1873 [47], Macrochaeta Grube, 1850 [48], Flabelligena Gillet, 2001 [49], Actaedrilus Jimi, Fujimoto and Inamura, 2020 [50] and Flabelligella Hartman, 1965 [51]; triangular and smaller in Chauvinelia Laubier, 1974 [52] and Helmetophorus Hartman, 1978 [51]; and reduced to small regions encircling the nuchal organs in Swima Osborn Haddock, Pleijel, Madin, and Rouse, 2009 [53] and Teuthidodrilus Osborn, Madin, and Rouse, 2011 [32]. When present, eyes can be one to three pairs in Acrocirrus and Macrochaeta. Head branchiae are present in Chauviniela, Heteromorphus, and Swima, and their number and shape (elongated or short and stout) are important in recognizing some species [52,54]. Nuchal organs exhibit great variation between genera, varying from simple straight ridges in Acrocirrus and Macrochaeta, to complex looped rings with branching appendages in Teuthidodrilus. Acrocirridae have a variable number of anterior achaetous segments, which can also vary greatly between species, in terms of number, length, distinctiveness, or modification in a "cephalic hood" [28]. The first of these is considered homologous to the peristomium. Segmentally arranged branchiae, also referred to as main branchiae, can be found as one to four pairs on the first anteriormost segments, e.g., ref. [55]. However, they can be easily lost upon collection, and their notable absence in Flabelligella may be an artefact. Main branchiae are elongated cirriform appendages in most species but take the shape of small rounded bioluminescent bombs in the species of Swima [53].

Parapodia are typically protruding lobes, except in Macrochaeta, where they are very reduced [56]. Chaetae may be compound, pseudocompound chaetae, hooks, paddle-like chaetae, and spinous chaetae. The nature and arrangements of chaetae are of systematic importance [57]. 


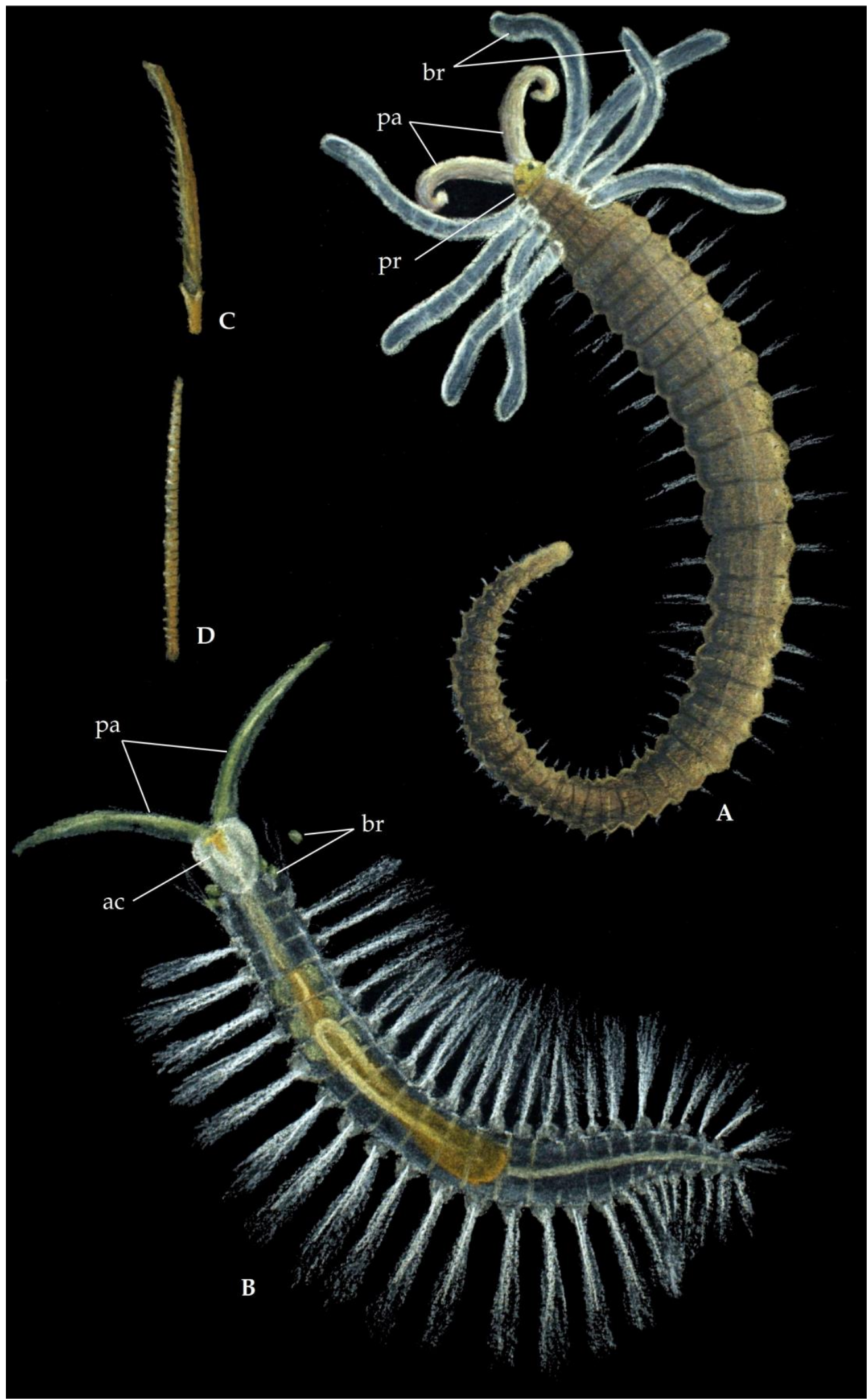

Figure 1. Family Acrocirridae, artistic representation. (A) Acrocirrus validus, approx. $5 \mathrm{~cm}$. (B) Swima bombiviridis, approx. $3.5 \mathrm{~cm}$. (C) Example of compound chaetae, approx. $100 \mu \mathrm{m}$. (D) Example of simple chaetae, approx. $100 \mu \mathrm{m}$. ac, anterior cephalic region; br, branchiae; pa, palps; pr, prostomium. Pastels and colour pencils from Maël Grosse (). (B) after Osborn et al. [53] and (C,D) after Hartman [58]. 


\subsection{Diversity and Phylogeny}

The family Acrocirridae has historically received little attention, with most species described around 1970 (Figure 2A). However, while this has not yet led to a significant rise in species descriptions, renewed interest in deep-sea pelagic habitats and cave habitats opens new perspectives for increased species descriptions in the future, e.g., refs. [53,59]. There are currently 45 described species of Acrocirridae in ten genera $[32,50]$ and at least two additionally new, undescribed species have been reported [59-61]. The majority of these species are described from the Pacific and Atlantic Oceans (Figure 3A) and belong to the benthic genera Acrocirrus (13) and Macrochaeta (12).

Phylogenetic analyses have inferred three clades within the family, congruent with previous systematic arrangements of the group [50,57], with a clade including Macrochaeta, Actaedrilus and Acrocirrus, splitting next to a monophylum, which includes two sister clades: Flabelligella-Flabelliseta-Flabelligena and the pelagic forms Swima-Teuthidodrilus. Whereas each of these clades is well supported by morphological characters, the genera within are sometimes poorly defined and described based on a combination of, often plesiomorphic, characters, emphasizing the need for a systematic review of the family $[22,49,62]$. Furthermore, several species, potentially important to understand character evolution within the group, remain to be formally described [53,59-61].

\subsection{Biogeography}

Despite the increasing attention that the group has received lately, knowledge of the global distribution of Acrocirridae remains fragmentary, and it is difficult to infer generalized distribution patterns for most species. The better understood are, by far, members of Acrocirrus and Macrochaeta, which have been reported mostly in shallow waters around the world, e.g., refs. [55,63,64]. Members of Macrochaeta are often recorded from shallow sandy bottoms in the North Atlantic Ocean, especially in the North Sea and Scandinavia [12,65], but also in the Mediterranean and the Canary Islands [28,63]. In contrast, species of Acrocirrus are more common in the Pacific Ocean, with 11 species found around Japan, Australia, New Zealand, Hawaii, and the east coast of North America, typically intertidally under rocks $[55,64]$. There are, of course, exceptions such as A. frontifilis, which is fairly common in the Mediterranean and nearby areas of the Atlantic [66]; or M. pege and M. multipapillata from Washington State and the Galapagos Islands, respectively [22,67]. Members of Flabelligena and Flabelligella are often found deeper and prefer mud, with several records both in the Atlantic and the Pacific Ocean $[49,58,62]$, as well as the morphologically bizarre M. polyonyx, whose generic status demands closer examination [68]. Finally, the actual distribution of other acrocirrids can barely be inferred, since they have been mostly known from anecdotical evidence until recently, when technological advances have started to shed light on their actual habitats in the deep sea.

\subsection{Biology and Ecology}

Acrocirridae is an exception among other families within Cirratuliformia as it contains both benthic and pelagic species, a feature only shared by Flabelligeridae. Benthic species are usually found in sandy or muddy sediments and sometimes on hard bottoms on or within which they crawl [28]. Pelagic species have for now only been recorded from deep sea, and ecological preferences are difficult to ascertain at this stage. Three undescribed species are notable for being exclusively found in anchialine caves [59,69]. These species are, however, benthic and morphologically similar to their marine relatives, in contrast to other annelids colonizing cave habitats that exhibit secondarily adaptations to swim in the water column $[15,70-72]$. 


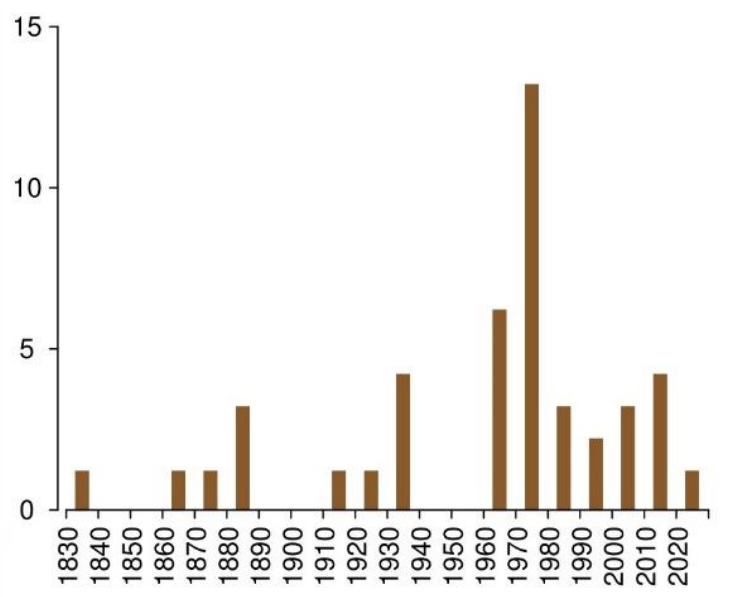

A Acrocirridae
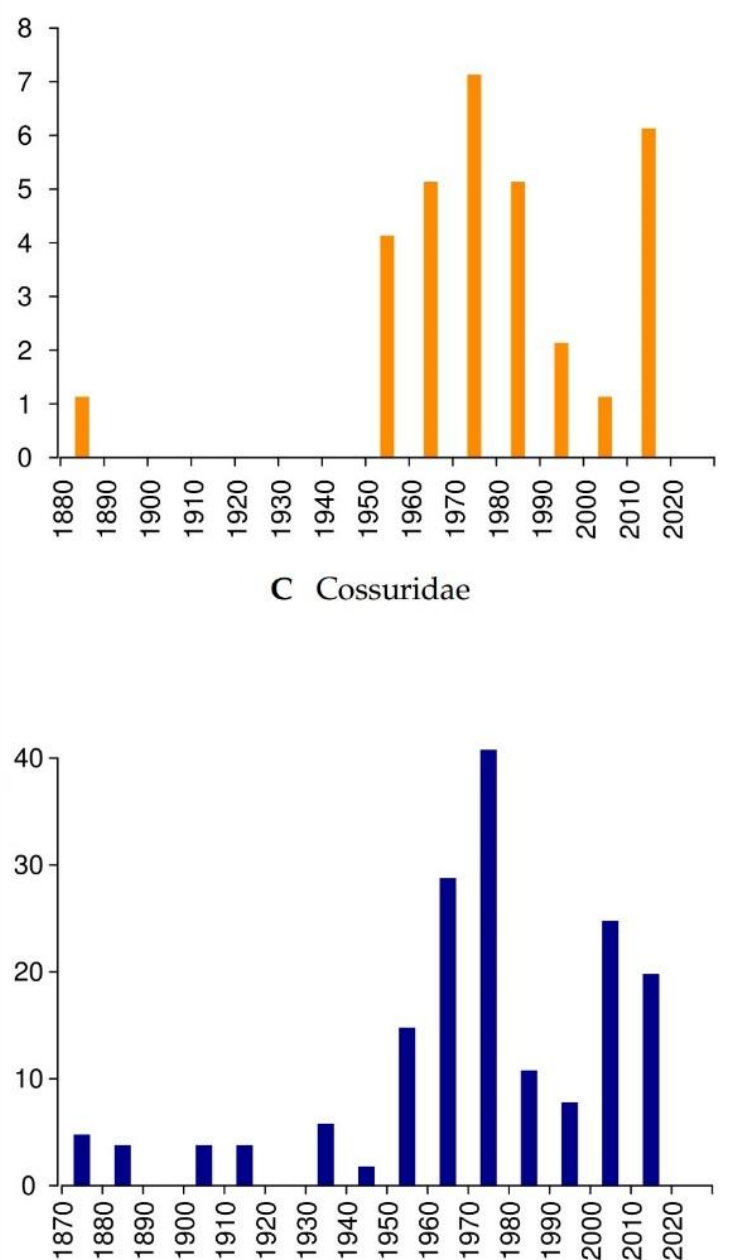

E Paraonidae

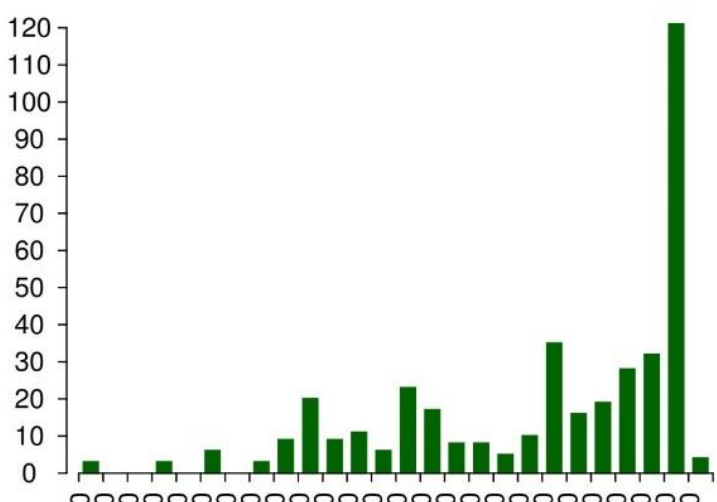

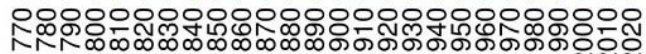

B Cirratulidae

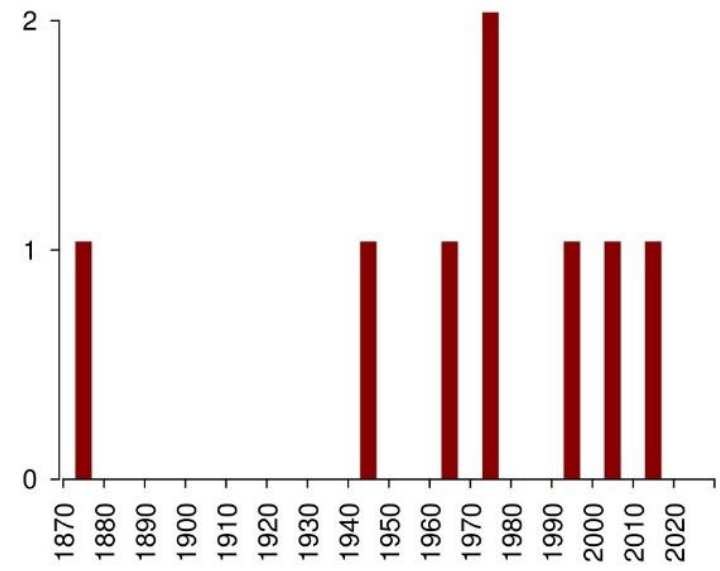

D Longosomatidae

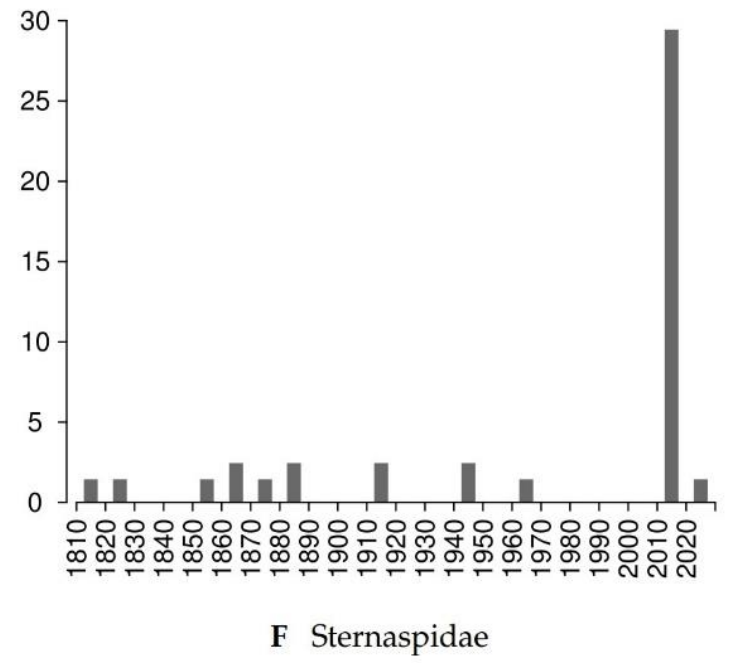

Figure 2. Number of species described per decade per family: (A) Acrocirridae; (B) Cirratulidae; (C) Cossuridae; (D) Longosomatidae; (E) Paraonidae; (F) Sternaspidae. 


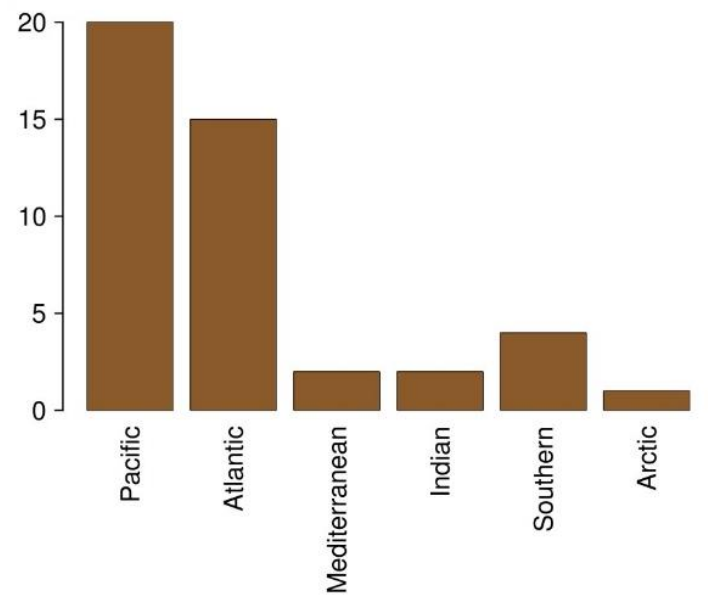

A Acrocirridae

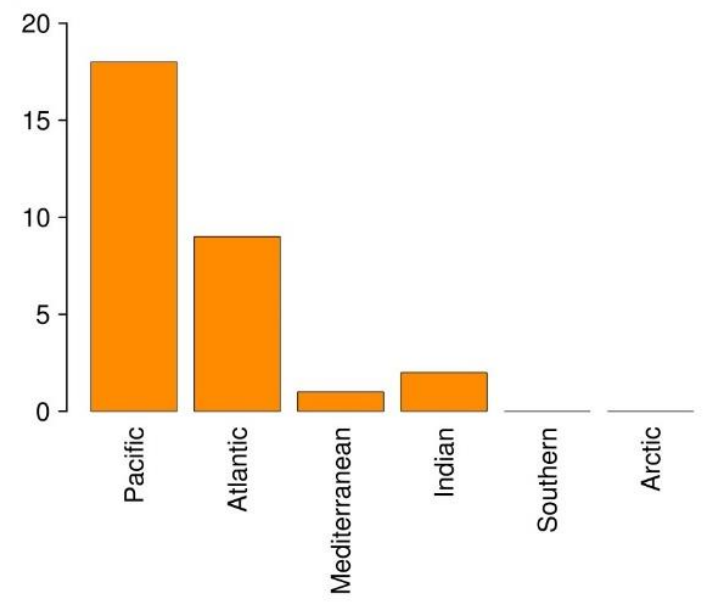

C Cossuridae

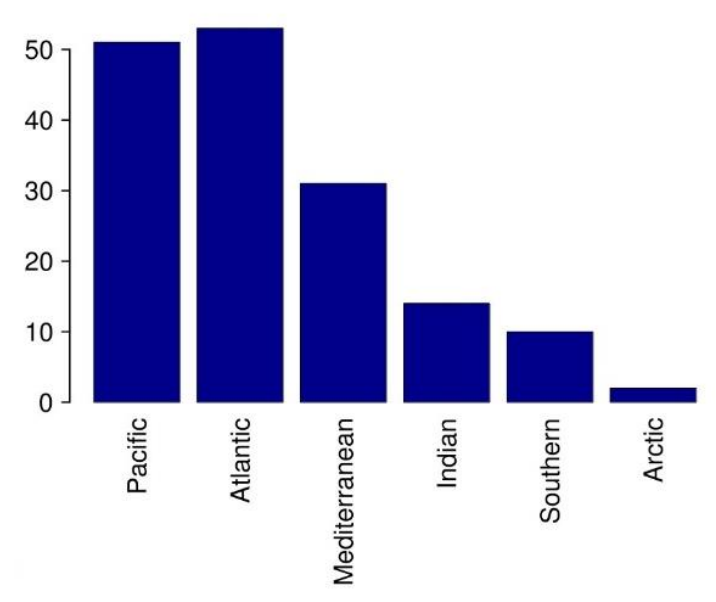

E Paraonidae

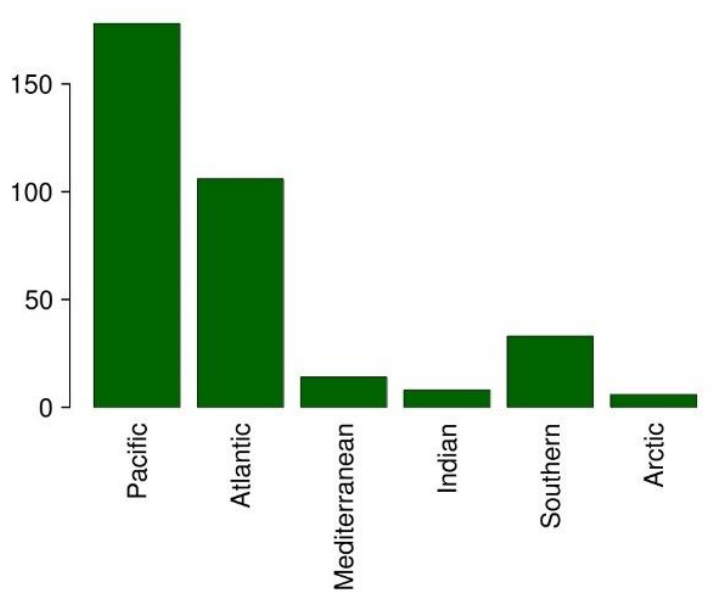

B Cirratulidae

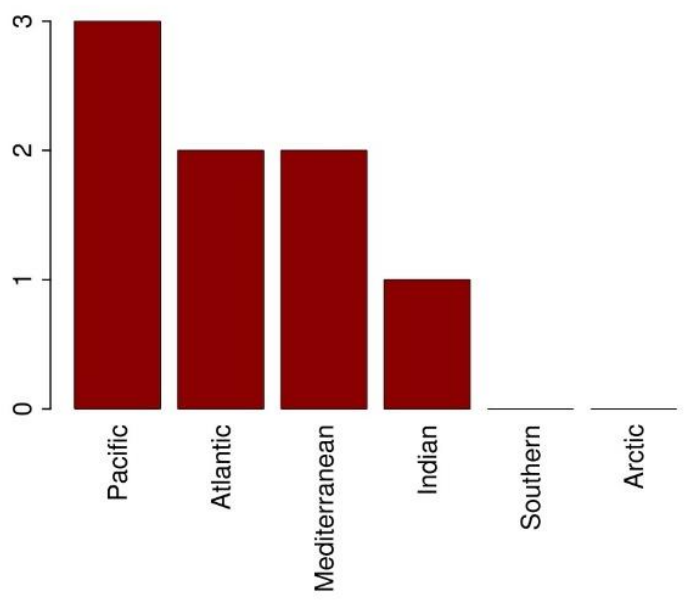

D Longosomatidae

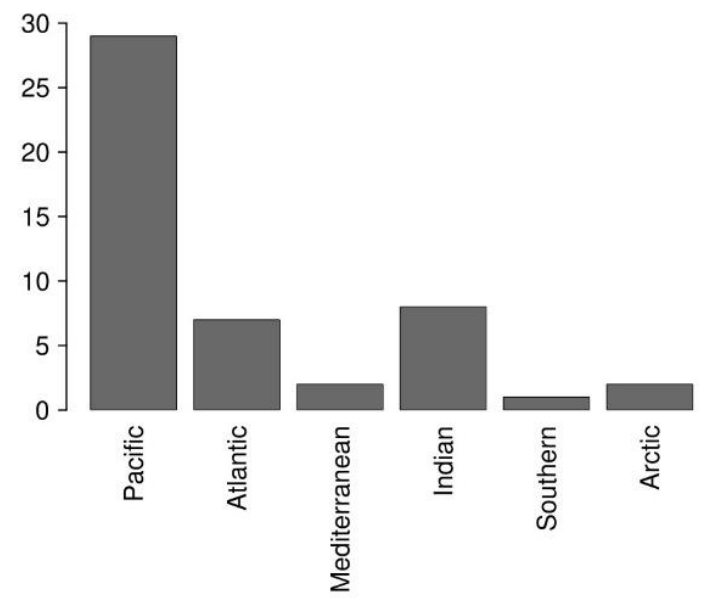

F Sternaspidae

Figure 3. Number of species described (types, localities) per ocean/sea per family: (A) Acrocirridae; (B) Cirratulidae; (C) Cossuridae; (D) Longosomatidae; (E) Paraonidae; (F) Sternaspidae.

Most benthic acrocirrids are classified as selective deposit feeders [73], while pelagic species are probably suspension feeders [32]. 
Little is known about the reproduction and development of acrocirrids, but the few species studied all reproduce sexually (e.g., Macrochaeta clavicornis (Sars, 1835) [74]). Details on sperm transfer, fertilization, and larval development are still unknown in Acrocirridae

\subsection{Conclusions}

While we expect an increased interest in Acrocirridae in the coming years with the study of new habitats, little is still known about this relatively small, but diverse family of annelids. The wide morphological variation within the family, presumably correlated with the secondary colonization of pelagic and deep-sea habitats, together with the existence of fossils, highlights the potential of Acrocirridae for future ecological and evolutionary studies.

\section{Cirratulidae (Ryckholt, 1851) Including Ctenodrilidae (Kennel, 1882)}

Annelids belonging to the Cirratulidae Ryckholt, 1851 [23] form a rather morphologically homogenous group. They are elongated, cylindrical worms, with numerous segments and parapodia reduced or absent [29]. The anterior thoracic region is sometimes expanded, with narrower segments, as are sometimes the last few segments. Their grooved tentacles and long filamentous branchiae, which most species bear on many segments, are characteristic features (Figure 4). There are four main groups within Cirratulidae, although they do not necessarily reflect monophyletic groups: (1) multitentaculate cirratulids (Cirratulus Lamarck, 1818 [75], Cirriformia Hartman, 1936 [76], Timarete Kinberg 1866 [77], Fauvelicirratulus Çinar and Petersen, 2011 [78], and Protocirrineris Czerniavsky, 1881 [79]) are characterized by numerous filamentous dorsal tentacles; (2) bitentaculate cirratulids (Aphelochaeta Blake, 1991 [80], Caulleriella Chamberlin, 1919 [81], Chaetocirratulus Blake, 2018 [82], Chaetozone Malmgren, 1867 [11] (Figure 5A), Kirkegaardia Blake, 2016 [83], and Tharyx Webster and Benedict, 1887 [84]) are characterized by a single pair of thick dorsal tentacles; (3) Dodecaceria Ørsted, 1843 [85] is characterized by a single pair of thick lateral tentacles and a comparatively smaller number of branchiae; (4) ctenodrilids (Ctenodrilus Claparède, 1863 [86], Aphropharynx Wilfert, 1974 [87], Raphidrilus Monticelli, 1910 [88], and Raricirrus Hartman 1961 [89] (Figure 5B)) are characterized by their lack of tentacles. The status of Ctenodrilidae Kennel 1882 [90] as a distinct family has been controversial [91], but several morphological characters as well as recent molecular phylogenetic analyses support its inclusion within Cirratulidae (e.g., [92,93]. All cirratulids are benthic, and most live in sediments, except for Dodecaceria, which is a strictly hard-bottom tubicolous genus, as well as many multitentaculate species.

\subsection{Morphology}

The identification of cirratulids can be challenging, since most species are small (ranging between a few millimetres and a couple of centimetres) and present characters that can be difficult to observe and interpret. Important species characters include the shape of the prostomium and peristomium, presence of eyes, pattern of tentacles (paired or multiple) and branchiae, presence of a first achaetous segment, shapes and distribution of chaetae, shapes of potentially modified segments, presence of body regionalization, presence of dorsal/ventral grooves/ridges, shape of the pygidium, and methyl green/blue staining patterns [29].

The prostomium varies from narrow and conical (most bitentaculate species) to broad and wedge-shaped (most multitentaculate species) but exhibits little variation in shape and length. A pair of eyespots or two rows of multiple eyespots (the number of which can vary through ontogeny) may be present in some species. The length of the peristomium, number of annulations, and their shape and degree of completeness are of systematic importance [29]. A problematic character for bitentaculate cirratulids is the possible presence of one or two achaetous segments between the peristomium and the first chaetiger, since interpreting an achaetigerous ring as a segment or as a peristomial annulation remains ambiguous without histological studies, and therefore has been interpreted differently 
among systematists, affecting how the placement of the first branchiae and tentacles are described [94]. Tentacles in cirratulids take two shapes, a single pair of thick appendages in bitentaculate cirratulids and Dodecaceria (thicker than the branchiae and easily distinguished from them) or as a variable number of thin filaments in multitentaculate cirratulids (similar to branchiae in shape and length). The position of tentacles (either paired tentacles or tentacular filaments) is important in recognizing species. Among multitentaculate genera, the position of tentacles is used in recognizing different genera. Tentacular filaments arise from a single anterior segment, accompanying the first pair of branchiae in Cirratulus; from one or two anterior segments, or accompanying the first pair of branchiae or posterior to it in Cirriformia; from two or more anterior segments, posteriorly to the first pair branchiae in Timarete; from two or more anterior segments, usually accompanying the first pair branchiae and in small numbers in Protocirrineris; and from the first segment, accompanying the first pair of branchiae in Fauvelicirratulus [78]. Branchiae are also useful for recognizing both genera and species. Branchiae arise in pairs (two branchiae per segment) typically just above the notopodia in most species, but shift to mid-dorsum posteriorly in Timarete and are more numerous in Fauvelicirratulus. Like the position of the tentacles, the position of the first pair of branchiae is of systematic importance.

Chaetae include different types of capillaries and acicular spines. Compound chaetae are absent. Shape, number, arrangement, and distribution are important in determining species and genera. Smooth capillaries are present in all genera except Raphidrilus and are the only type of chaetae found in Aphelochaeta and Protocirrineris [95,96]. Serrated capillaries are characteristic of Kirkegaardia and Raphidrilus $[95,96]$. Knobby-tipped spines are present in small numbers in Tharyx [80]. Bidentate hooks in well-separated neuroand notopodia are characteristics of Caulleriella and can sometimes be found in Chaetozone [82]. Unidentate spines are characteristics of Chaetozone when arranged in spread fascicles on elevated parapodial membranes creating disctinctive cinctures (Figure 5C), and characteristic of Chaetocirratulus when few and not arranged in cinctures [82]. Unidentate spines are also found in Timarete, Fauvelcirratulus, Cirratulus, and Cirriformia. Short serrated spines are found in Raricirrus, Ctenodrilus, and Aphropharynx (Figure 5D). Stout spoon- or chisel-shaped chaetae are characteristic of Dodecaceria. However, the use of chaetae presents several practical complications. First, complete specimens are needed to be certain of the presence or absence of certain types of chaetae, in particular the spines of bitentaculate genera. Second, the nature and distribution of chaetae can vary with ontogeny, making these characters difficult to assess in immature specimens [97]. Finally, there is no unified terminology for the different types of chaetae found in cirratulids, e.g., ref. [98].

The pygidium is usually simple and rounded, sometimes pointed (e.g., Chaetozone elakata Blake and Lavesque 2017 [99]), and can present terminal cirri in a few species (e.g., Caulleriella venefica Doner and Blake 2006 [100]). However, cirratulids often break upon collection, so the pygidium can rarely be examined.

Methyl green or methylene blue staining can reveal distinct patterns for some species, mostly of bitentaculate genera, e.g., refs. [99,100]. However, not all species exhibit this pattern, and staining success can vary with the specimens' condition and preservation method.

\subsection{Diversity and Phylogeny}

There is a total of 355 species of Cirratulidae, belonging to 16 genera $[1,29,101]$. The bitentaculate Cirratulidae comprise approximately 227 species. Nearly 142 new species of bitentaculate Cirratulidae were described in the past 20 years, compared to 15 multitentaculate species, four species of Dodecaceria, and four Ctenodrilidae (Figure 2B). Most species were described from the Pacific and Atlantic Oceans, with 168 and 106 type localities, respectively, while the Mediterranean Sea, Indian Ocean, and Arctic Ocean are considerably less studied, with less than 10 species described from the Indian Ocean (Figure 3B). More recently, more than 40 species have been described from the Clarion-Clipperton Fracture Zone in the North-East Pacific, the Southern Ocean, Antarctica, and South-East America $[82,94,102]$, which are otherwise poorly known areas. Other areas where cirratulids 
have recently been studied and new species described include the Caribbean Sea, Hawaii, Korea, North-East Atlantic, and South Africa [103-106]. In particular, the recent description of five new species of Protocirrineris from South Africa and South America is remarkable as it represents important progress in the study of a little-known genus in a poorly studied geographical area $[97,107,108]$.

Although several studies have inferred phylogenetic hypothesis of part or all of Cirratulidae, the monophyly of each genus has not yet been assessed, and the relationships between members of the family are not fully resolved. Several species of Cirratulus have been recovered as a monophyletic group based on COI, 16S, and 28S data [91,93]. Cirriformia and Timarete have not been recovered monophyletic based on COI and $16 \mathrm{~S}$ data $[91,93]$. Raricirrus is recovered monophyletic using COI and $16 \mathrm{~S}$ data with two species sequenced [91]. The genera Chaetozone and Aphelochaeta were also recovered monophyletic using COI and $28 \mathrm{~S}$ data, although with few reliably identified species of Aphelochaeta included [93]. The monophyly of multitentaculate cirratulids as a whole is supported by COI, $28 \mathrm{~S}$, and 16S data [91,93]. However, the monophyly of bitentaculate cirratulids as a whole is not supported, and relationships between larger groups (multitentaculate, bitentaculate, Dodecaceria, and ctenodrilids) remain unresolved [93].

\subsection{Biogeography}

Bitentaculate cirratulids show the broadest distribution range, occurring in all oceans and from the intertidal zone to the abyss. Species of Ctenodrilidae show a similar distribution pattern, although based on fewer records, probably reflecting their smaller size and difficulties in identification. Ctenodrilus serratus (Schmidt, 1857) [109] is well known for being often found in aquaria, and Aphropharynx heterochaeta Wilfert, 1974 [87] was described from an aquarium in Germany. The multitentaculate cirratulids and Dodecaceria species mostly occur in coastal shallow water around the globe. As for many other groups, the North American and European coasts have the most records for the family, reflecting sampling efforts in these areas.

As for many other species, early described cirratulids have been recorded worldwide. Species such as Chaetozone setosa, Cirratulus cirratus, or Timarete punctata (Grube, 1858) [110] have long been thought as cosmopolitan. Recent examination of these records and of specimens collected worldwide revealed species complexes in each case [98,111,112]. Ctenodrilus serratus was one of the early annelids investigated as potential cryptic species [113]. However, cosmopolitan species also exist. Raricirrus jennae Magalhães, Linse, and Wiklund, 2017 [91] was recorded from sunken wood in the northeast Pacific and hydrothermal vents in the Atlantic sector of the Southern Ocean. One species within the Timarete punctata complex has been recorded from the South Atlantic Ocean off Brazil, the Caribbean Sea, and Hawaii [112]. Chaetozone corona Berkeley and Berkeley, 1941 [114] has been described from California but subsequently reported from Brazil, Turkey, Greece, and France, e.g., refs. [115-117].

\subsection{Biology and Ecology}

Bitentaculate cirratulids mostly live in sediments, burrowing just under the surface, from intertidal areas (e.g., Chaetozone christiei Chambers, 2000 [118]) to abyssal plains (e.g., Aphelochaeta abyssalis Blake, 2019 [102]), although some can be found on hard substrates or coralline algae (e.g., Caulleriella viridis Langerhans, 1881 [119]). Multitentaculate cirratulids live in more varied habitats, including soft bottoms (e.g., Cirriformia tentaculata Montagu, 1808 [120]), rocks and crevices (e.g., Protocirrineris socialis Blake, 1996 [95]), or coralline algae (e.g., Protocirrineris strandloperarum Elías, Simon, and Sarracho-Bottero, 2019 [107]). Dodecaceria species burrow into mollusc shells and calcareous rocks (e.g., Dodecaceria concharum), or build their own tubes, creating rocklike colonies (e.g., Dodecaceria fewkesi Berkeley and Berkeley, 1954 [121]). Ctenodrilids, like bitentaculate cirratulids, occur from the intertidal to the deep ocean (e.g., Raricirrus variabilis Dean, 1995 [122]). 


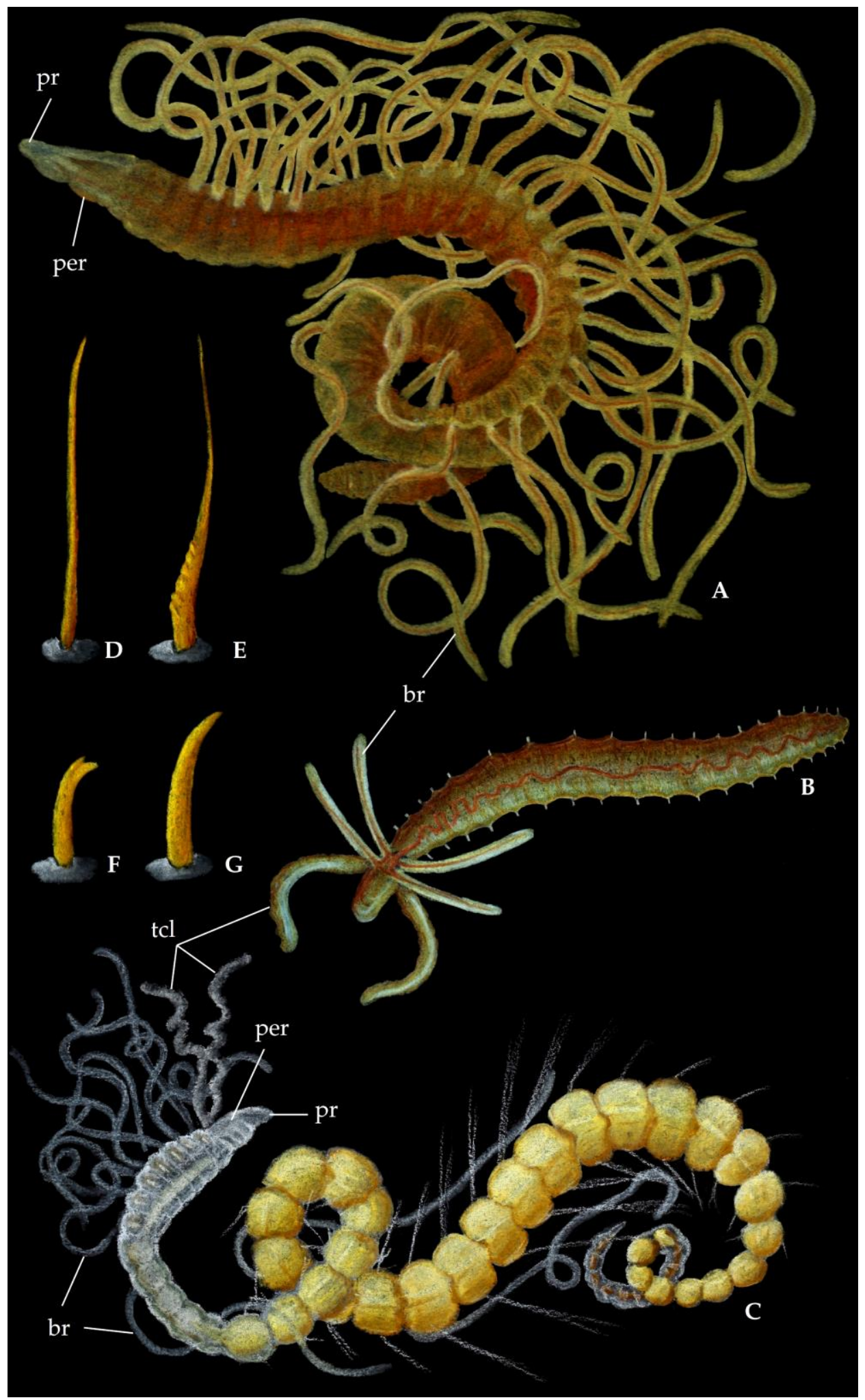

Figure 4. Family Cirratulidae, artistic representation. (A) Cirratulus sp., approx. $2 \mathrm{~cm}$; (B) Dodecaceria concharum, approx. $8 \mathrm{~mm}$; (C) Aphelochaeta sp., approx. $3 \mathrm{~mm}$; (D) example of smooth capillary chaeta, approx. $70 \mu \mathrm{m}$; (E) example of serrated capillary chaeta, approx. $70 \mu \mathrm{m}$; (F) example of bidentate hook, approx. $50 \mu \mathrm{m}$; (G) example of unidentate spine, approx. $100 \mu \mathrm{m}$. br, branchiae; per, peristomium; pr, prostomium; tcl, tentacles. Pastels and colour pencils from Maël Grosse $\odot$. 
Cirratulids can occur in high numbers in sediments (e.g., up to 10,000 inviduals per square meter [123]). Several studies also highlight the preference of some species for organically enriched sediments [122,124-127], making them potential bioindicators. Cirratulids and ctenodrilids also exhibit a certain tolerance to some heavy metals, such as arsenic, copper, chromium, cadmium, and zinc [128-131].

Cirratulids are surface or subsurface deposit feeders, using their tentacles to collect particles [73].

Reproductive strategies can vary greatly between (and sometimes within) species of cirratulids and ctenodrilids, and that of Cirratulidae have last been reviewed by Petersen [132]. Species may reproduce exclusively sexually (e.g., Cirratulus cirratus), or both sexually and asexually (e.g., Dodecaceria concharum). Most species are gonochoristic, although sexual dimorphism has rarely been observed, and a few are known to be simultaneous hermaphrodites (e.g., Chaetozone vivipara (Christie, 1984) [133]). Larval development includes direct lecithotrophic, and occasionally viviparous development.
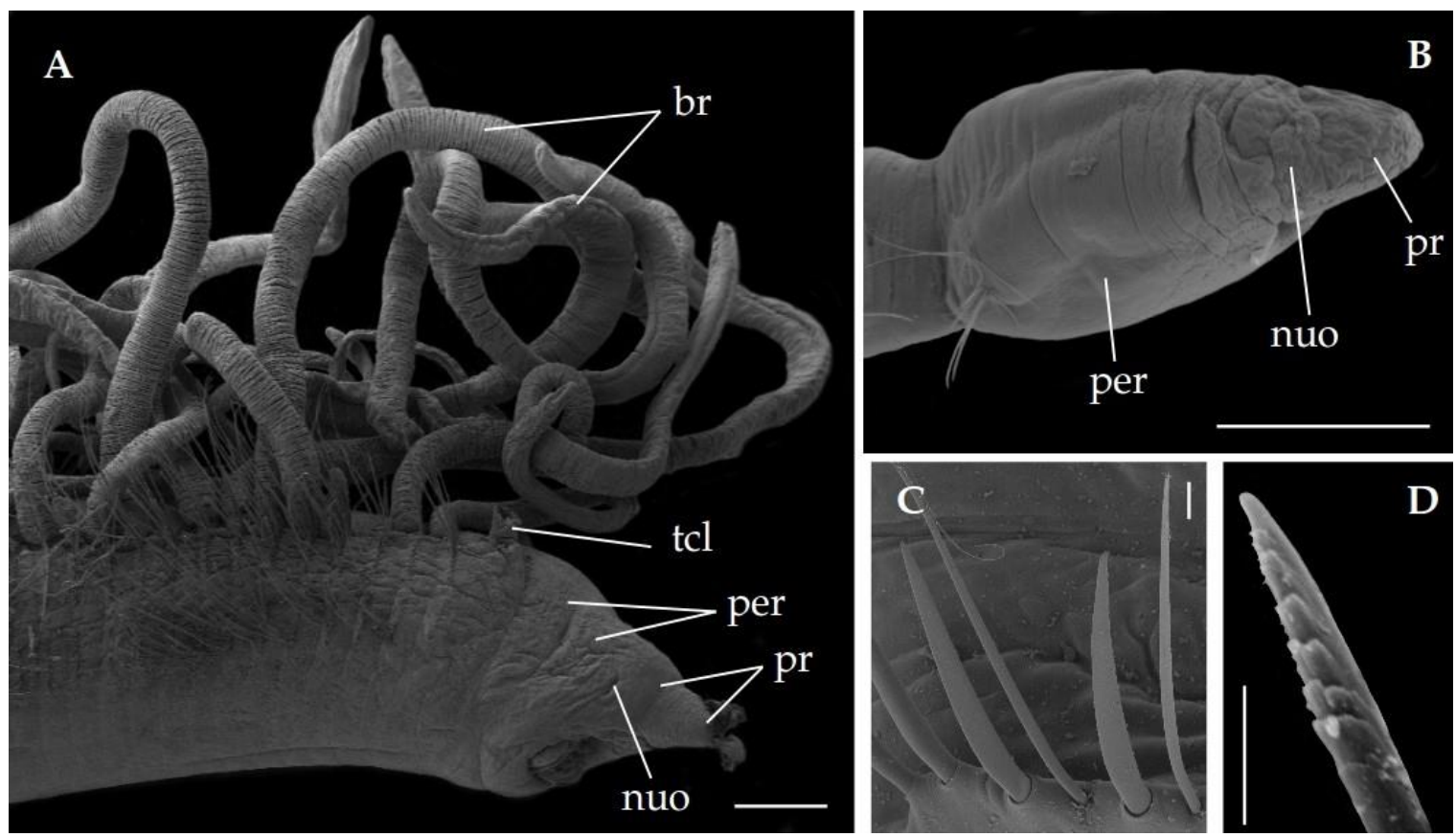

Figure 5. Scanning electron micrographs of Cirratulidae and Ctenodrilidae. (A) Chaetozone sp., anterior in lateral view; (B) Raricirrus beryli Petersen and George, 1991 [124], anterior in lateral view; (C) Chaetozone sp., neuropodial chaetae; (D) Raricirrus beryli, neuropodial chaeta. br, branchiae; nuo, nuchal organ; per, peristomium; pr, prostomium; tcl, tentacle base. Scale bars: (A,B) $300 \mu \mathrm{m}$; (C) $20 \mu \mathrm{m}$; (D) $10 \mu \mathrm{m}$.

\subsection{Conclusions}

Considering that we still find new species even in well-studied areas, the presence of cryptic diversity, and the number of areas still unexplored, we can say that even if Cirratulidae is already a very diverse group, there are still a great many species left to be discovered and described. In such a diverse group like, characterized by morphological characters that are difficult to interpret, molecular data can be a great tool for species discovery and description in support of morphological work. A better understanding of species boundaries will also help better understand their distribution and all the other life history traits of the species.

\section{Cossuridae Day, 1963}

Annelids belonging to the family Cossuridae Day, 1963 [5] are small, threadlike worms, easily recognizable owing to a single unpaired branchial filament attached to the dorsal 
side of one of the anterior segments (Figure 6). Their body is cylindrical, and the anterior part is more muscular and frequently slightly flattened. Anterior (thoracic) and posteriormost segments are shorter than they are wide, and middle segments are longer and often beaded [34]. Cossurids lack head appendages; their parapodia are reduced, and chaetae emerge directly from the body wall. The pygidium typically bears three cirri.

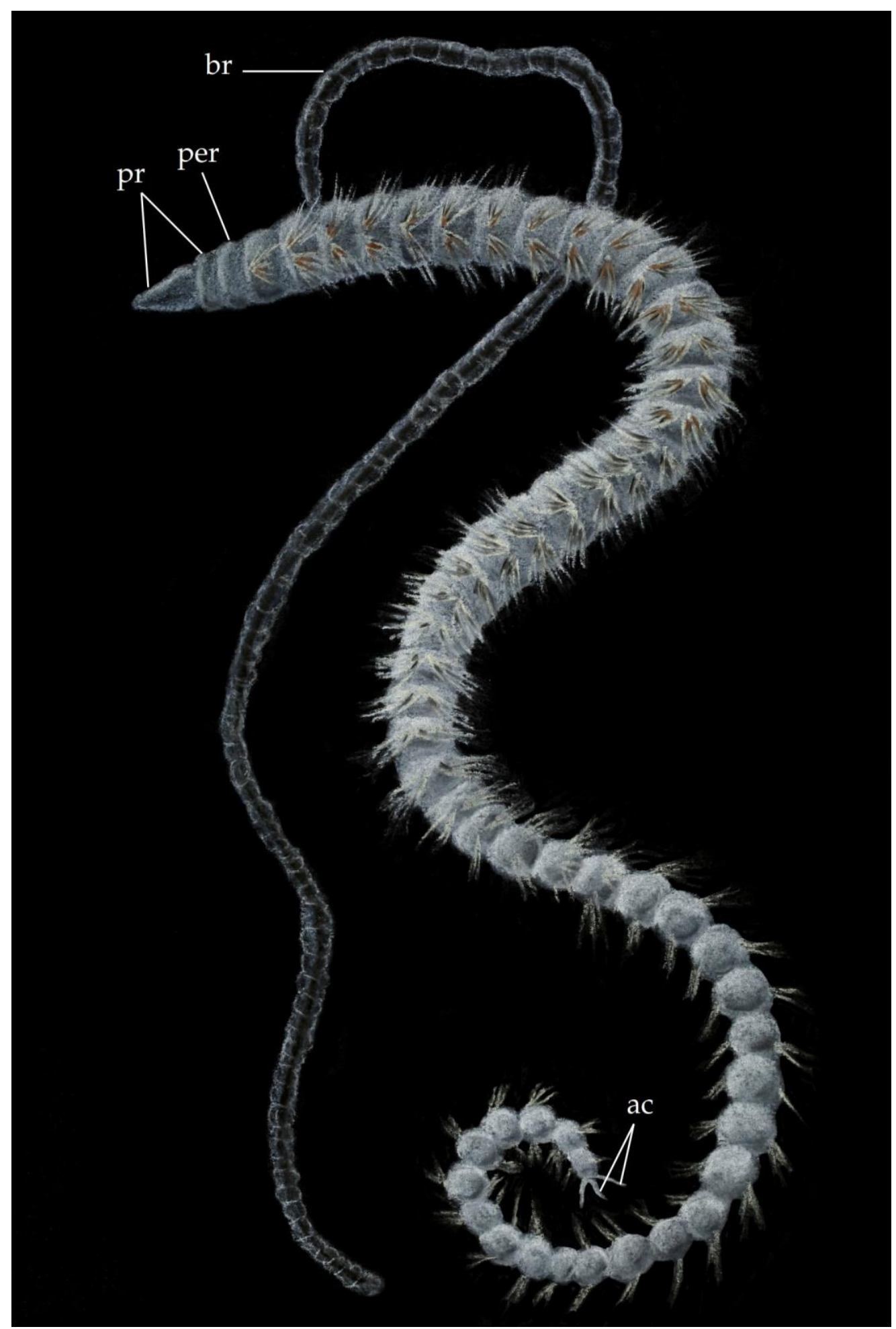

Figure 6. Family Cossuridae, artistic representation. Cossura soyeri, $4 \mathrm{~mm}$. ac, anal cirri; br, branchial filament; per, peristomium; pr, prostomium. Pastels from Maël Grosse (C). 


\subsection{Morphology}

Cossuridae specimens are difficult to distinguish morphologically and do not have many taxonomically informative characteristics. Their appearance is simple and quite uniform: low body regionalization, simple head without appendices, soft unarmed proboscis, absence of parapodial lobes, and simple uniform chaetae (Figure 7). The most important characteristics used for cossurid identification are the shape of the prostomium, position of the branchial filament, number of thoracic chaetigers, chaetal shapes, and shape of the pygidium. Methyl green staining patterns are also useful for identifying Cossuridae species [134]. Characteristics such as the number of anterior achaetous segments and the number of uniramous parapodia are not useful for cossurid systematics.

The shape of the prostomium is typically conical or triangular from a dorsal view (which is the most common shape in Cossuridae) to round, trapezium-shaped, and almost quadrangular; Cossura ginesi Liñero-Arana and Díaz-Díaz, 2010 [135] shows an unusually shaped prostomium with anterior horns. The branchial filament typically arises from chaetiger 2 or 3 or the border between them (Figure 7A,B). Exceptionally, it might arise from chaetiger 4 or 5 . The exact position of the branchial filament is typically difficult to establish and requires strictly lateral positioning of the worm during investigation or detailed scanning electron microscopy (SEM) images. Furthermore, the previous segment may have dorsal extensions, from which the branchial filament arises [136,137]. This difficulty produced different interpretations regarding the position of the branchial filament in the same species. For example, C. consimilis Read, 2000 [138] was described with the filament arising from the anterior border of chaetiger 3; however, in a redescription, the filament was found to be attached to the segmental border between chaetigers 2 and $3[136,138]$.

The number of anterior achaetous rings is not systematically informative, as the first of them has been shown to be of prostomial origin and not seen in relaxed specimens [139]. The number of thoracic segments is often difficult to count. Generally, thoracic segments are short and dorsoventrally flattened, and chaetae emerge from their anterior borders; abdominal segments are longer, frequently appearing beadlike, and chaetae emerge from their central areas (Figure 7C,D). In some species previously assigned to Cossurella Hartman, 1976 [62], the transition from thorax to abdomen is very distinct because the abdominal segments bear spinelike or acicular-like chaetae, whereas in other species, variations in the shape of the segments and positions of chaetae are gradual, the border indistinct, and accurate counting difficult [137], which has questioned the validity of species separation based on these characteristics [138]. The position of chaetal bundles has been proposed as a main indicator of transition [136], the first abdominal segment being the first segment which bears chaetae situated in its centre. The number of thoracic segments increases with the worm size and varies considerably between individuals of the same species. Thus, for accurate identification, it is necessary to examine several adult specimens.

Chaetal types and arrangement are very similar across cossurids, yet important for species identification. The first chaetiger is uniramous, and all others are biramous. In early descriptions, the number of segments with uniramous parapodia was erroneously used as a characteristic for distinguishing species, e.g., ref. [140]. Thoracic chaetae are arranged in two vertical rows on both rami (Figure 7B). All thoracic chaetae are capillaries of different lengths and thicknesses, with a cylindrical shaft and more or less flattened hirsute blades. Typically, chaetae of the anterior row are shorter and thicker than those of the posterior row, and neurochaetae are frequently thicker than notochaetae. In some species, coarse thickened chaetae tend to be short, curved, and abruptly tapered. Differences in size and shape of chaetae gradually diminish towards the abdomen. SEM is the most reliable method for examining these chaetae. 

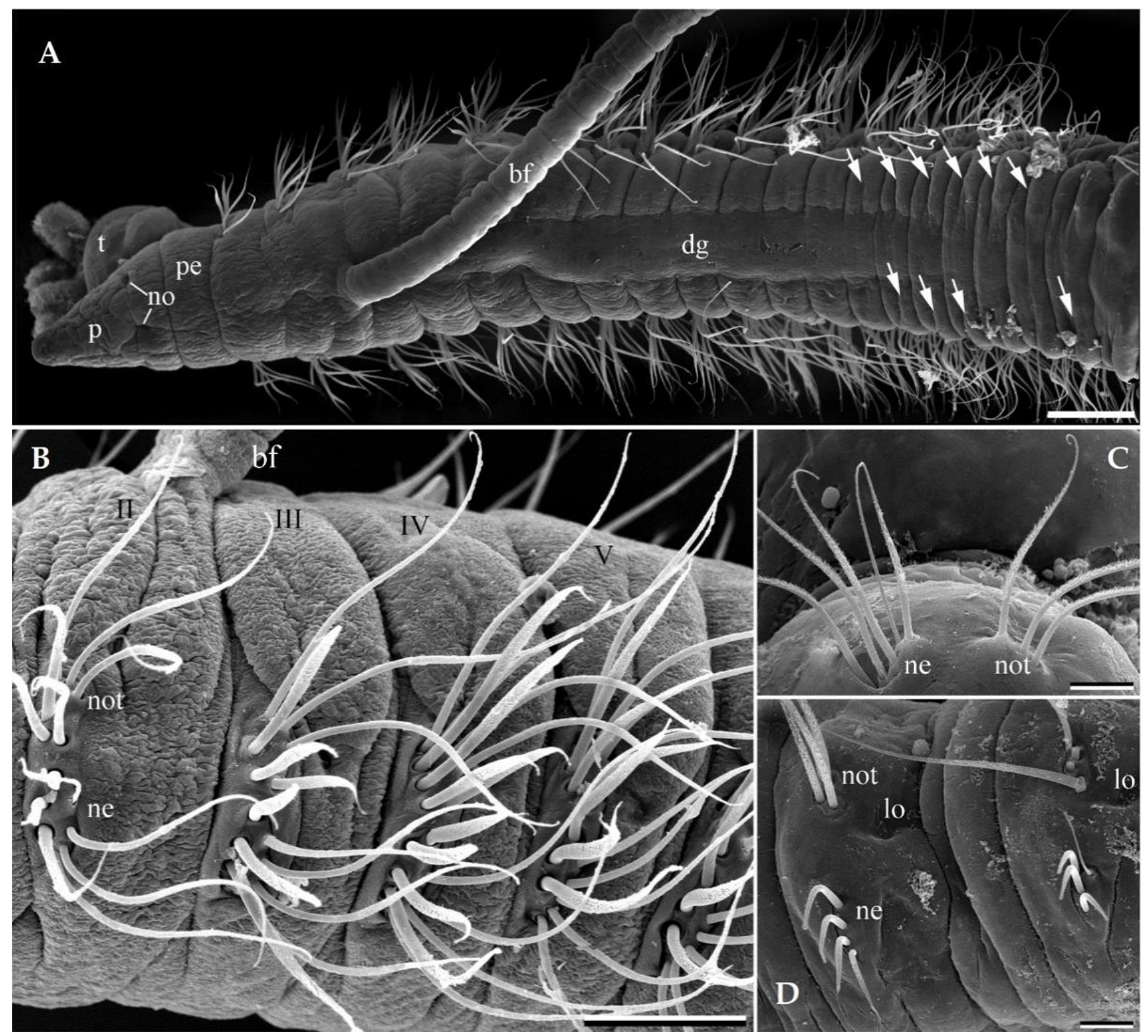

Figure 7. Cossura pygodactylata. (A) Thorax and beginning of the abdomen, dorsal view; arrows indicate additional transversal furrows dividing segments; (B) anterior thorax, lateral view; (C) abdominal chaetiger, anterior view; (D) two abdominal chaetigers, lateral view. bf, branchial filament; dg, dorsal groove; lo, lateral organ; ne, neuropodia; no, nuchal organs; not, notopodia; p, prostomium; pe, peristomium; t, buccal tentacles. Scale bars: (A) $100 \mu \mathrm{m} ;$ (B) $60 \mu \mathrm{m}$; (C,D) $20 \mu \mathrm{m}$. All reproduced from Zhadan et al. [139] with permission.

Pygidial appendages are important for species identification. Most cossurid species have three long anal cirri, one of which is ventral and two are dorsal. In addition to anal cirri, Cossura pygodactylata has 12-20 fingerlike intercirral processes, whereas juveniles of this species do not possess cirri or appendages [139,141]. In C. pseudakaina Ewing, 1987 [142], the pygidial rim is scalloped and bears only one short ventral cirrus; in C. coasta Kitamori, 1960 [143], three pygidial cirri are branched at their ends. Unfortunately, cossurids are very fragile, and usually only anterior ends are found in collections. In a size assessment study using standard procedures for benthic samples, only $0.3 \%$ of Cossuridae were represented by complete specimens [144] In many species, the pygidium remains unknown [138]. 


\subsection{Diversity and Phylogeny}

The Cossuridae family comprises only one genus with 29 species. The taxonomic history was described by Ebbe and Blake [34]. During the past 20 years, eight new species have been described. These descriptions were produced by revisions of museum collections $[136,138]$ or by exploring new areas such as northeastern Venezuela [135], the Congo deep-sea fan [145], and northern and northeastern Brazilian tropical estuaries [36]. The number of species described per decade is shown in Figure 2C. The largest number of cossurid species was described in the Pacific Ocean $(n=18)$, and more than one third of this number was from the Pacific coast of North America (Table 1). There are 10 species described in the Atlantic Ocean; most of these also have type locality in the North and South American coasts, and only one is from the Mediterranean Sea (Table 1). Only two species have type locality in the Indian Ocean, and none in the Arctic and in the Southern Ocean (Figure 3C). This can be explained, in part, by different levels of scrutiny of studies on marine benthos in different regions; however, this does not apply generally, since European waters were investigated in detail and for longer periods of time than any other.

Table 1. Species of Cossuridae described from different regions.

\begin{tabular}{lcl}
\hline \multicolumn{1}{c}{ Geographic Distribution } & $\begin{array}{c}\text { No. of } \\
\text { Species }\end{array}$ & Species \\
\hline Pacific Ocean & $\mathbf{1 8}$ & \\
\hline NE Pacific, North American coast & 7 & $\begin{array}{l}\text { C. bansei, C. brunnea, C. candida, C. modica, C. pygodactylata, } \\
\text { C. rostrata, C. sima }\end{array}$ \\
\hline SE Pacific, South American coast & 4 & C. abyssalis, C. alba, C. chilensis, C. laeviseta \\
\hline NW Pacific, Japan, China & 3 & C. coasta, C. duplex, C. aciculata \\
\hline SW Pacific, Australia, New Zeeland, Fiji & 4 & C. consimilis, C. hutchingsae, C. keablei, C. queenslandensis \\
\hline Atlantic Ocean & $\mathbf{1 0}$ & \\
\hline NW Atlantic, North American coast & 3 & C. delta, C. longocirrata, C. pseudokaina \\
\hline NW Atlantic, Caribbean Sea, South American coast & 2 & C. pettibonea, C. ginesi \\
\hline NE Atlantic, Mediterranean Sea & 1 & C. soyeri \\
\hline SW Atlantic, South American coast & 2 & C. heterochaeta, C. yacy \\
\hline SE Atlantic, Congo deep-sea fan & 2 & C. flabelligera, C. platypus \\
\hline Indian Ocean & $\mathbf{2}$ & C. dayi, C. dimorpha \\
\hline
\end{tabular}

Currently, there is no study on phylogenetic relationships within Cossuridae. One of the reasons for this may be the deficiency of information on species morphology and incompleteness of descriptions. Many species are known only from single or a few incomplete specimens; descriptions are frequently insufficient and sometimes use invalid characteristics (such as the number of achaetous segments or segments with uniramous parapodia), whereas the most important characteristics of those species remain unknown $($ see $[36,138]$ for review). The second reason is the lack of molecular genetic data for cossurids. GenBank contains only a few sequences of two Cossura species. It is unclear why molecular genetics of these annelids have not been studied so far.

Therefore, the family Cossuridae requires revision. Re-investigation of type material and a large number of specimens per species are needed to reveal intraspecific variability and to obtain comprehensive morphological character data on species. Sequence data of mitochondrial and nuclear genetic markers are required to produce molecular phylogenetic trees of this family. Numerous questions need to be answered-e.g., What is the plesiomorphic condition of different characteristics? Which are the most basally splitting cossurids? Do morphological characteristics and molecular genetic data give congruent phylogenetic information? Do former Cossurella species form a monophyletic group? Are 
there clear patterns of character evolution within the family, suggesting the delineation of other genera?

\subsection{Biogeography}

Examining distribution patterns of cossurids is frequently associated with difficulties regarding species identification. Most cossurid species are known only from type localities or the same biogeographic region, whereas other species were reported far from type localities, such as Cossura ginesi or C. soyeri Laubier, 1963 [135,136,146]. Cossura longocirrata is the first described species of the family, and for many years, all cossurid findings were assigned to this species. Re-examination of material from different localities has revealed much confusion with Cossura pygodactylata, and C. soyeri, C. ginesi, C. pygodactylata, and C. coasta are other putative examples of cossurid species complexes that may need re-examination. The reported wide distibutions of several cossurid species can be probably ascribed to both cryptic species and misidentification, and comparative analysis of morphology and genetic investigations are needed to confirm these records.

A few notes on cossurids as introduced species have been made. Callier et al. [147] suggested that Cossura pygodactylata was introduced at the Southsea Marina (south coast of England) by boats, subsequently colonizing the area and probably extending its distribution range from within the marina to its environs. Cossura coasta was suggested as a Lessepsian migrant, which entered the Mediterranean Sea through the Suez Canal [148]. This species is included in lists of Mediterranean alien species as a cryptogenic and questionable species $[149,150]$ and also listed as invasive in India [151,152].

\subsection{Biology and Ecology}

Members of Cossuridae inhabit sediment, such as silt, clay, and sometimes fine sand, usually occurring within the upper $10 \mathrm{~cm}$ layer. They can be found from the intertidal to the abyss (e.g., Cossura flabelligera Zhadan, 2017 [145], at a maximum depth of $4719 \mathrm{~m}$ ). Cossuridae species differ based on their preferred layer of sediment. For example, C. chilensis was found mainly at 5-10 $\mathrm{cm}$ depth [153], and Cossura sp. were found near the surface $(0-5 \mathrm{~cm})$ and mostly at $0-2 \mathrm{~cm}$ sediment depth [154]. Cossurids do not build permanent tubes; however, worms typically inhabit temporary tubes consisting of mucus with adhered sediment particles. In C. flabelligera, this mucous sheath is quite strong, persists during washing, and resembles the tunic of flabelligerids [145].

Ecological preferences also vary among Cossuridae species. Cossurids seemed rare within benthic communities before the second half of the 20th century, probably reflecting the methods used for washing sediments and the use of mesh size of $1.5 \mathrm{~mm}$, too large to retain most cossurid species. The current use of mesh sizes of $500 \mu \mathrm{m}$ (or even finer) have revealed that cossurids are actually abundant and often the dominant species in many areas such as the Atlantic coast of France and Spain [141,155]. All cossurids are marine, but some species inhabit estuaries and tolerate reduced salinity as well as substantial changes in salinity, e.g., Cossura coasta [156,157], C. delta [140,158-160], C. yaci [36], and C. pygodactylata [161]. Ecological differences can indicate presence of cryptic species. Some species exhibit a broad depth range, from shallow subtidal to lower slope, and it has been suggested that separate populations of these species occupy narrower depth zones [34]. Cossurid populations are resilient and may even respond positively to bioturbation $[162,163]$. Some cossurids are also indicators of different types of pollutants, such as heavy metals [147,154,160,164-169] or organic pollutions [156,170-172], and are potentially oportunistic. Some species, such as C. coasta, have been considered to belong to groups III and IV of the AZTI's Marine Biotic Index (AMBI) [173-177], which is commonly used to evaluate pollution based on ecologic groups of different sensitivity to organic matter. In contrast, C. candida in Los Angeles Harbor was found to be a characteristic species of healthy environments $[178,179]$. Similarly, in New Zealand, C. consimilis was predominant under pristine conditions and was thus categorized in group I: species which are very sensitive to organic enrichment and occur in unpolluted environments [180]. 
Cossurids are motile subsurface deposit feeders, collecting food particles with their short ciliary tentacles from the walls of their burrows [73].

The reproduction biology of Cossuridae is poorly known. Annual recruitment with spring peaks has been shown in several species [139,181]. Planktonic larvae are most probably absent in Cossuridae, as they have never been observed. However, there have been a few sightings of juvenile cossurids with natatory chaetae in the water column [138, 182], suggesting a semi-planktonic dispersal phase in some species, which must be taken into account during morphological studies.

\subsection{Conclusions}

Cossuridae-despite the small number of described species-remains poorly known. The most pressing problems are insufficient species descriptions, gaps in the knowledge of reproduction and development, questionable species distributions, numerous misidentifications, possible cryptic species, lack of genetic and morphological data, and no phylogenetic hypotheses.

\section{Longosomatidae (Hartman, 1944)}

Annelids belonging to the family Longosomatidae Hartman, 1944 [25] are small, cylindrical, elongated worms, with few segments. They are characterized by their distinct body regionalization, with enlarged anterior and posterior ends, and thin, very long middle segments (Figure 8).

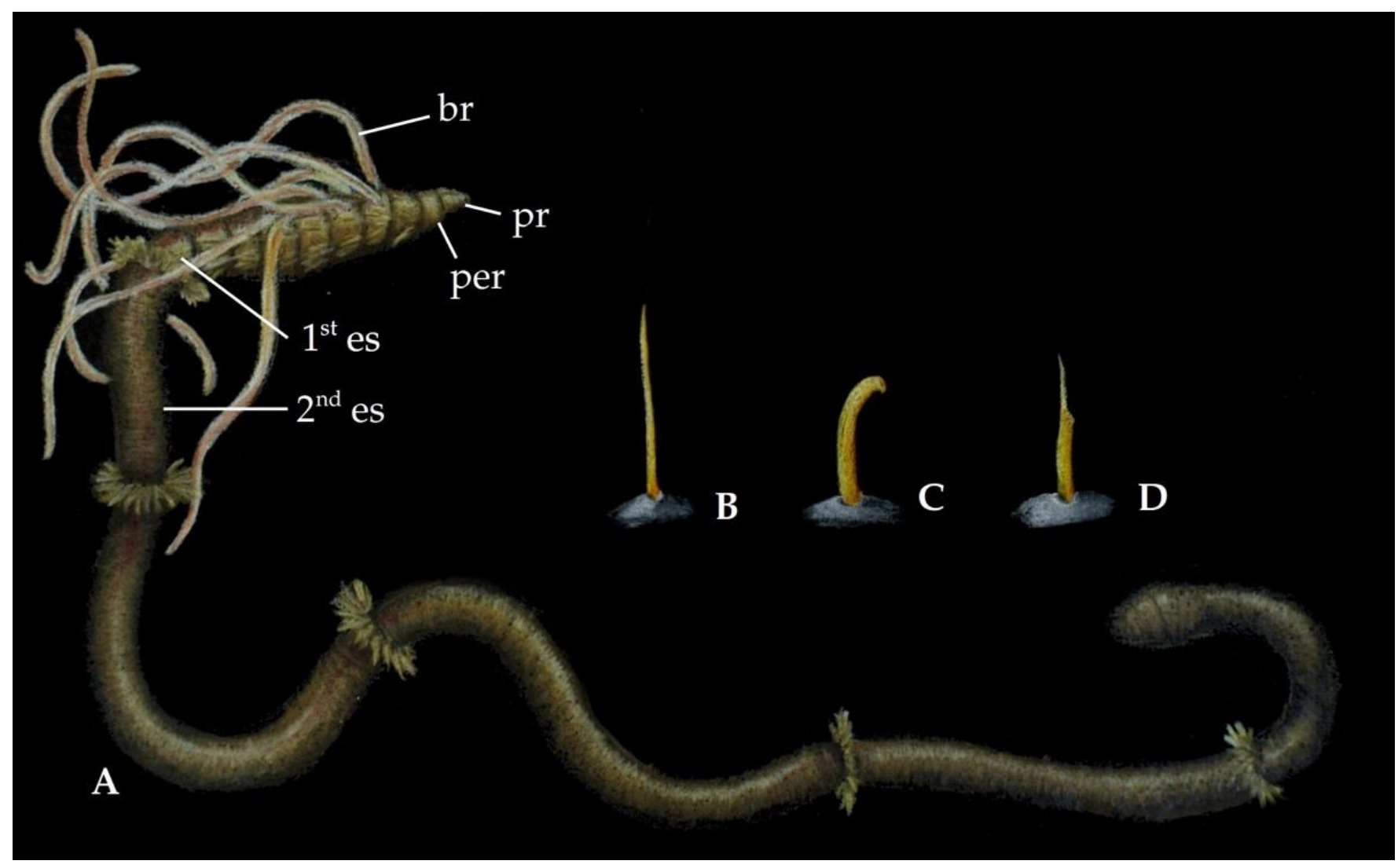

Figure 8. Family Longosomatidae, artistic representation. (A) Heterospio sp., $4 \mathrm{~cm}$ (imaginary colours-there is no record of observation of any live specimen-and shown without palps as most species are presented); (B) capillary chaetae, $100 \mu \mathrm{m}$; (C) hook, $80 \mu \mathrm{m}$; (D) aristate spine, $80 \mu \mathrm{m}$. 1st es, first elongated segment; 2nd es, second elongated segment; br, branchiae; per, peristomium; pr, prostomium. Pastels and colour pencils from Maël Grosse @. (B-D) after Hartman [183,184]. 


\subsection{Morphology}

The prostomium is usually conical and rounded, with a pair of nuchal organs. The peristomium is short and the presence of palps is confirmed for several species [185]. The thorax is usually six to eight chaetigers with a variable number of branchiae. The number of thoracic and abdominal segments and pairs of branchiae are of systematic relevance. The abdominal segments are narrow and greatly elongated, with many chaetae typically arranged in a cincture anteriorly. The length of the first elongated segment is an important character to differentiate species. The posterior end, which is usually lost during the collecting process, is typically composed of inflated segments.

Chaetae include capillaries of various lengths and acicular spines, whose shape and arrangement are taxonomically relevant, although the lack of a unified terminology for chaetal morphology complicates the assessment of this character [185].

The pygidium is a simple ring.

\subsection{Taxonomy and Phylogeny}

Longosomatidae is a small family, with eight species in the monotypic genus Heterospio Ehlers, 1874 [44] (Figure 2D), although many species probably remain undescribed. Longosomatids are known from the Atlantic, Indian, and Pacific Oceans, as well as from the Mediterranean Sea, with respectively two, one, three, and two species described from each area (Figure 3D).

\subsection{Biogeography}

Longosomatids have been found from intertidal sediments to abyssal plains. Heterospio longissima Ehlers, 1874 [44] was originally described from the Atlantic Ocean and has been subsequently recorded from the Indian and Pacific Oceans [45]. However, as for many early described species, some of these records might concern other species and the distribution range of $H$. longissima might be more restricted. In particular, records from the Indian Ocean have been shown to belong to another species, H. indica, which is so far known to be only from this part of the world [45].

\subsection{Biology and Ecology}

Little is known of the biology and ecology of this family, as most of the species have rarely been encountered and no individuals described alive. They inhabit soft sediments and are probably subsurface deposit feeders [73].

\subsection{Conclusions}

Longosomatidae is a small family, and its members are rarely encountered. Therefore, it is probably the least studied member of Cirratuliformia, and very little is known about its biology. It is certain that more species are still to be described.

\section{Paraonidae Cerruti, 1909}

Annelids belonging to the family Paraonidae Cerruti, 1909 [6] are usually small to medium-sized, and characterized by a relatively simple, conservative morphology, which makes identification at the species level challenging (Figure 9). The body shows a certain heteronomy, with an anterior part wider and often slightly flattened, bearing a variable number of branchiae; and a posterior part, cylindrical, with reduced parapodia and often possessing modified chaetae in either the notopodium or the neuropodium. The pygidium is usually semicircular, subtriangular, or bilobed, and bears two or three anal cirri. 


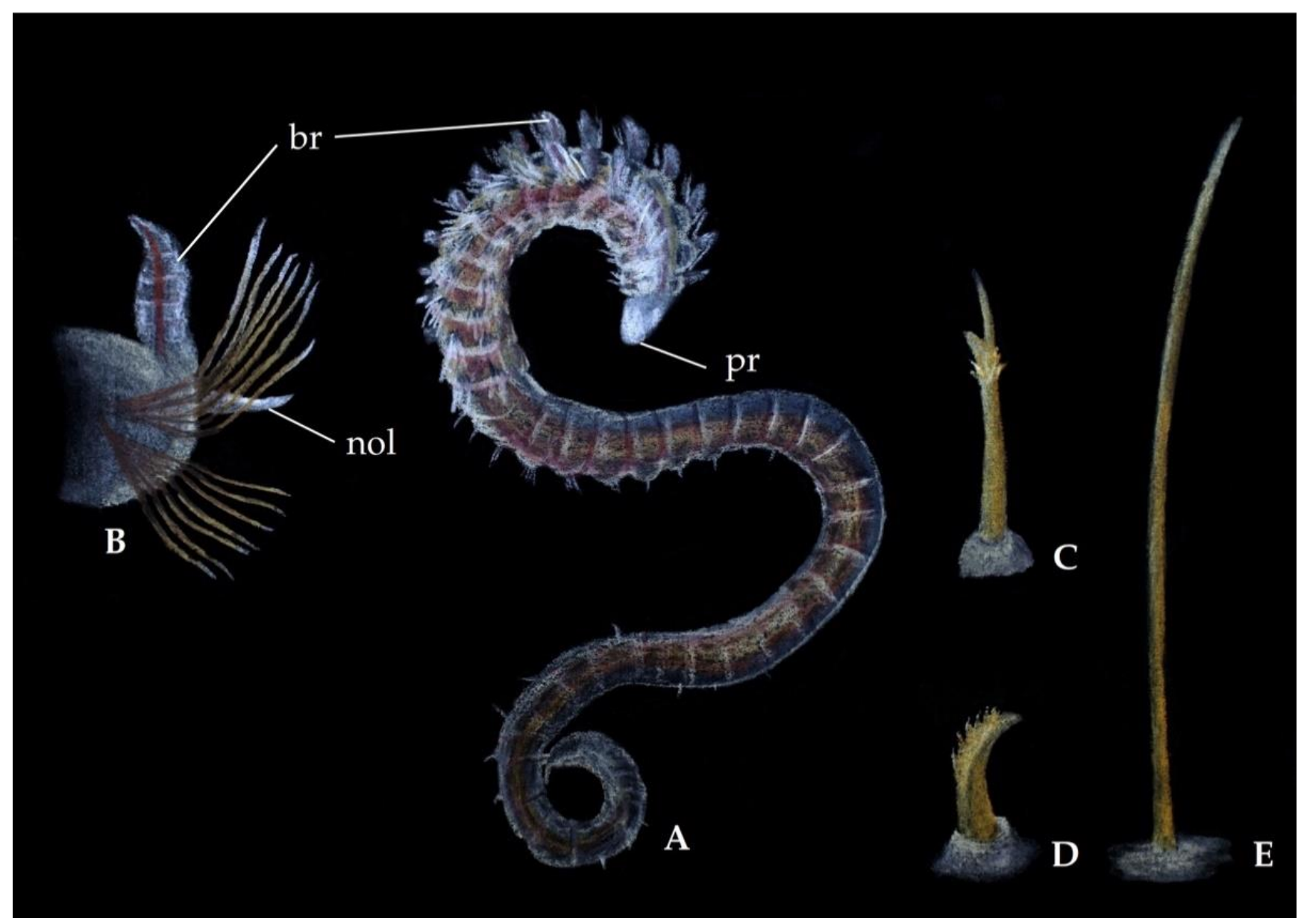

Figure 9. Family Paraonidae, artistic representation. (A) Aricidea assimilis, $5 \mathrm{~mm}$; (B) transversal view of a parapodium, $400 \mu \mathrm{m}$; (C,D) neurochaetae, $30 \mu \mathrm{m}$; (E) capillary chaetae, $40 \mu \mathrm{m}$. br, branchiae; pr, prostomium; nol, notopodial lamellae. Pastels and colour pencils from Maël Grosse (). (B-E) after Blake [35,186].

\subsection{Morphology}

Paraonidae are characterized by a higher degree of regionalization in comparison with other Cirratuliformia, showing a distinction between anterior (thoracic) and posterior (abdominal) regions. Nonetheless, the transition between thoracic and abdominal regions is gradual, with intermediate segments showing transitionnal features. Diagnostic morphological characters include shape of the prostomium, presence or absence of an antenna, number of pre-branchial and branchial chaetigers, pattern of notopodial and neuropodial post-chaetal lobes, and presence of modified chaetae. Despite these characters, the identification of paraonid species is often hindered by their fragility, making it impossible to appreciate several morphological features, as well as by the scarce information on the ontogenetic variation in key morphological characters [37,187].

The prostomium is usually triangular, sub-trapezoidal, or rounded, but in some species of the genera Aricidea (e.g., Aricidea trilobata Imajima, 1973 [188]) and Sabidius (e.g., Sabidius cornatus (Hartman, 1965) [58]), it is more or less strongly trilobed. Sabidius species are peculiar in having a thickened cuticle on the anterior margin of the prostomium [189]. The presence or absence of a single antenna has been originally used to separate different genera [35], but it has been shown that all monophyletic lineages within Paraonidae include both species with and without antenna [14]. The usefulness of the presence and shape of antennae in species descriptions has been instead confirmed by several systematics works [190-192], although the occurrence of a branched antenna, originally considered diagnostic $[193,194]$, is most likely the result of issues in the regeneration or pathological conditions [14,195]. Eyes are usually simple eyespots located in the ventral part of the 
prostomium, and their presence is not always easy to identify in preserved material, as these structures can fade after preservation in ethanol. Examination of live material showed, however, that in conspecific individuals at different growth stages, eyes may be present or absent, and that juvenile individuals usually show eyespots, while adults lack them. The peristomium is largely fused with the prostomium, and difficult to sort out; the alleged presence of a distinct, achaetous peristomial ring in the original descriptions of some species $[84,196]$ has later been proved to be a preservation artefact $[39,194]$. Prostomial and peristomial sensory structures often include ciliary bands, a terminal retractile organ and paired nuchal organs[39]. These features might represent useful taxonomic characters, but their informativeness remains to be determined. The proboscis is soft and unarmed.

The first chaetigers are devoid of branchiae and, usually, of modified chaetae. The majority of species has three pre-branchial chaetigers, but four pre-branchial chaetigers have been observed in members of the genera Aricidea, Cirrophorus, and Paradoneis, and adult individuals of Aricidea simonae Laubier and Ramos, 1973 [197] have branchiae starting at chaetiger 3. The genus Levinsenia has typically five to eight pre-branchial chaetigers [39]. Although the first descriptions suggested a certain degree of intraspecific variation in the number of pre-branchial chaetigers [39,198,199], the variability of this character has been re-evaluated [194,200], and the number of pre-branchial chaetigers seems to be informative even at the supraspecific level [14]. Ontogenetic change in the number of pre-branchial chaetigers observed in A. simonae [187] is in fact an exception to a general trend of intraspecific stability of this character. Branchiae are paired and are usually flattened and ciliated, showing the presence of two blood vessels, and limited to a certain number of anterior segments. The number of branchiae in the vast majority of species increases with the body size $[39,201]$, and the branchial region does not usually exceed the first third of the body length. An exception is represented by Cirrophorus nikebianchii Langeneck, Barbieri, Maltagliati, and Castelli, 2017 [201], showing a very high number of branchial pairs, which might represent an adaptation to hypoxic environments [192]. Abranchiate species are known in almost all genera, usually from abyssal environments [39].

Parapodia in Paraonidae are reduced, biramous, and the majority of chaetae are thick, curved capillaries, becoming thinner and straighter posteriorly. In addition, several modified chaetae, usually restricted either to the neuropodia or to the notopodia, occur in both parapodial rami in Paradoneis eliasoni Mackie, 1991 [202], Paradoneis strelzovi de León-González and Diaz-Castañeda, 2011 [203], Paradoneis andreae López and Sikorski, 2017 [204], and C. nikebianchii. Modified notochaetae occur in the genera Cirrophorus and Paradoneis and are usually lyrate or derived from typical lyrate chaetae through thickening of one of the rami; Paradoneis spinifera (Hobson, 1972) [205] and Paradoneis drachi Laubier and Ramos, 1974 [197] are characterized by unbranched notopodial spines. Modified notochaetae usually start either at the last pre-branchial chaetiger or in the branchial region, and in species with thickened, acicular chaetae, they are usually lyrate in the branchial region, becoming thicker afterwards. Modified neurochaetae exhibit a wide variation in shape ranging from thickened capillaries to strong hooks or spines, sometimes with additional hairs or a sub-terminal hyaline sheath. The shapes of modified neuro chaetae were employed by Strelzov [39] to diagnose infrageneric groups, although without real phylogenetic meaning $[187,201]$. However, the shape and distribution of modified noto- and neurochaetae remain as useful diagnostic features. Chaetigers usually carry notopodial post-chaetal lobes, as cirriform, tubercular, or digitiformprotrusions of the body wall, whose shape, variation, and distribution along the body are often useful to discern species, particularly within Cirrophorus and Paradoneis [39,206]. Neuropodial postchaetal lobes are limited to pre-branchial and branchial regions and usually inconspicuous, except for a few Aricidea species. Additional papillary structures have been reported in a few species and are usually considered as systematically informative [187,194,207].

The pygidium is usually semicircular or bilobed and bears three elongated anal cirri, except for species of Levinsenia, characterized by triangular pygidium with two cirri. Additional pairs of cirri have been reported in a few species, mostly interpreted as 
paedomorphic traits [208,209]; based on personal observations, additional pairs of pygidial cirri actually represent the notopodial post-chaetal lobes of differentiating chaetigers in the proliferation zone between metastomium and pygidium.

\subsection{Diversity and Phylogeny}

Despite the high diversity and abundance displayed in seas all over the world, Paraonidae have been the subject of relatively few comprehensive studies, and its evolution, species diversity, and ecology remain largely unknown [35,39]. The wrong assignment of early described species to Orbiniidae [210], Spionidae [211-214], and Cirratulidae [215], poor early descriptions $[84,216]$, and nomenclatural debates (See for example ICZN opinion 1139) have been sources of much systematic confusion.

For a long time, the family was considered species-poor and consisting of relatively few species with broad distributions. Currently, more than 150 Paraonidae species have been described, belonging to eight genera: Aparaonis Hartman, 1965 [58], Aricidea Webster, 1879 [210], Cirrophorus Ehlers, 1908 [215], Levinsenia Mesnil, 1897 [217], Paradoneis Hartman, 1965 [58], Paraonella Strelzov, 1973 [39], Paraonis Grube, 1872 [211], and Sabidius Strelzov, 1973 [35,39]. Descriptions of new species peaked in the 1960s and 1970s [39,58,188,197,199,207], and increased again in the 2000s and 2010s (Figure 2E). Nonetheless, the number of undescribed species might well be comparable with that of currently described ones [35], which most likely comprise large complexes of cryptic and pseudocryptic species [14,218]. Approximately half of the described Paraonidae species is associated with deep-sea environments (up to $6000 \mathrm{~m}$ depth), which are expected to host a high number of undescribed species [219].

Recent phylogenetic analyses suggest that the systematics of Paraonidae requires a thorough revision. The phylogenetic inference based on morphological data by Reuscher [220] confirmed Strelzov's synonymy between Cirrophorus and Paradoneis [39], while a molecular phylogeny [14] showed several inconsistencies between accepted genera and monophyletic clades retrieved. Species of the genus Paraonis were recovered nested within Aricidea, while Cirrophorus and Paradoneis species were intermixed in two different clades. A part of Aricidea represented a separate, morphologically homogeneous clade, sister to Levinsenia; for this clade, Langeneck et al. [14] described Blakeia, which is a junior homonym of Blakeia Kiriakoff, 1967 (Lepidoptera) and thus unavailable. A synthesis between contrasting morphological and molecular data and a systematic revision based on total evidence are still lacking for this family, while molecular sequences are lacking for the majority of the species, and several genera (such as Paraonella, Sabidius, and the subgenus Aedicira).

\subsection{Biogeography}

Paraonidae have been reported worldwide, from the intertidal zone [221] to bathyal and abyssal environments [39]. A similar number of Paraonidae species have been described from the Atlantic and Pacific Oceans (53 vs. 51); the Mediterranean accounts for a relatively high number of taxa (31), while only a few species have the type localities in the Indian Ocean, the Southern Ocean, and the Arctic Ocean (Figure 3E). The scarce information on Paraonidae diversity and distribution in some geographical areas, such as the tropical Eastern Atlantic Ocean and Indian Ocean, most likely reflects limited sampling efforts [39].

Some species have an alleged cosmopolitan distribution [39,186,222], whereas according to Strelzov [39] other species show a bipolar distribution, which could reflect the scarce knowledge on the diversity of paraonids in tropical and equatorial areas. Individuals of Levinsenia gracilis sampled in the Pacific Ocean were morphologically identical to Eastern Atlantic individuals [223], but another allegedly widespread species, Aricidea catherinae Laubier, 1967 [207], turned out to include several pseudocryptic lineages, with the taxon A. catherinae s s. likely restricted to the Mediterranean Sea [14]. On the other hand, several deep-sea species described for the Mediterranean Sea, and until recently considered endemic $[197,199,224]$, have been recently reported for the North-Eastern Atlantic Ocean $[194,204]$, suggesting that the restricted distribution of several deep-sea species 
might be an artefact due to limited sampling efforts. Many deep-sea species are in fact known only from type material, and other taxa, especially recently described ones, are under-reported due to the rather complex systematics of the group and the use of outdated identification keys.

Only two species of Paraonidae have been suggested to represent non-indigenous species. Aricidea fragilis Webster, 1879 [210], with type locality in the western Atlantic Ocean, has been proposed as potentially invasive in the Mediterranean [195,225]. Aricidea bulbosa Hartley, 1984 [226] was reported from the Sea of Marmara as a possible Lessepsian immigrant [227]. Reports of species far from their type locality are relatively frequent, but they are usually just names in species inventories and general ecological works [66,228], without descriptions of specimens. Given the high number of pseudocryptic lineages found in this family [14], it is far more likely that these records are misidentifications of native species [150] or refer to undescribed taxa [14].

\subsection{Biology and Ecology}

Paraonidae live on the surfaces of soft sediments, or in their uppermost layer, where they can reach high densities $[186,229]$. Many species build temporary mucous tubes, covered by sediment particles, which are difficult to observe due to their brittleness. Living animals reside in the sediment in a characteristic "corkscrew" position with the middle and posterior parts spiralled beyond the axis delineated by the anterior, which remains straight and bears the branchiae. A few species have been sporadically reported from hard-bottom assemblages [230], and some species show a strict association with seagrass and Caulerpa beds [231-233]. Sediment grain size and origin seem to affect distributions of congeneric species. In shallow environments, individuals occur in gravel, coarse sand, fine sand, and silt; infralittoral environments typically show a low Paraonidae diversity, with few co-occurring species, one of which is often dominant [196]. Deeper environments are characterized by the prevalence silt and clay and often show a higher species diversity, although in lower abundances [234]. Several species have been reported from a wide bathymetric range; for instance, Cirrophorus branchiatus Ehlers, 1908 [215] has been reported from 8 to $2700 \mathrm{~m}$. Other species are more strictly related to bathyal and abyssal depths [194]. Extremely wide bathymetric ranges are not uncommon among polychaetes, but this feature could actually be an artefact due to incorrect identification, or absence of reliable morphological features. The majority of Paraonidae species is typically marine and stenohaline, and only few species have been reported from brackish estuarine environments and coastal lagoons $[190,235,236]$. The occurrence of the same species in very different habitats could suggest the existence of cryptic species, rather than an extreme adaptability of a single species [14]. The same hypothesis can account also for the high number of species assumed to be cosmopolitan, or with very wide geographical distribution.

Paraonidae occurring in brackish environments usually exhibit a low tolerance to wide variations of salinity, and usually occur in enclosed environments with limited salinity variation, as well as in marine environments characterized by organic enrichment [201,237]. For this reason, Paraonidae occurring in brackish-water environments can be considered marine species, but with high tolerance towards eutrophic conditions, rather than brackishwater species.

Paraonidae were traditionally considered as subsurface deposit feeders [73]. However, a few detailed studies have demonstrated that Paraonis spp. feed on microbenthos and microbial films growing on the surface layer of the sediment without leaving their tubes. An active selection of food items has also been observed [238,239].

Reproduction remains largely unknown. Paraonids are usually gonochoristic, with extremely sporadic reports of hermaphrodite individuals [240]. In most species, mature individuals are found all year round [240]. Larvae are unknown, but brooding of juveniles is known [241]. This, together with the occurrence of epitokes [242] and the large size of eggs, suggests that this family might have lecithotrophic larvae or even direct development [243]. 


\subsection{Conclusions}

Although Paraonidae have been the subject of several detailed taxonomic studies, and are partially investigated with molecular tools, there are still several gaps in the knowledge of this family. The available molecular data support the widespread belief that a large number of species (perhaps the majority) is still undescribed [35,39]. Furthermore, some genera are still unknown from the molecular point of view, and the current systematic view is largely inconsistent with the phylogenetic reconstruction based on molecular data. The uncertain identity of some early-described species has consequences for the systematics of the group and represents one of the first issues that should be tackled. Lastly, the ecology and the biology have been studied only in a few species, and in particular, the reproduction of Paraonidae is still largely unknown.

\section{Sternaspidae (Carus, 1863)}

Sternaspidae Carus, 1863 [24] is a taxon easily recognized by the presence of a bilaterally symmetrical ventro-caudal shield (Figures 10 and 11). The masklike shape and prominent colouring of this shield resembles the eye region of owls and earned Sternaspidae the common name "mud owls" [244]. Present knowledge on the morphology, biology, and systematics of the group has been summarized by Sendall and Salazar-Vallejo [244] and (including anatomy) by Fiege [31,245].

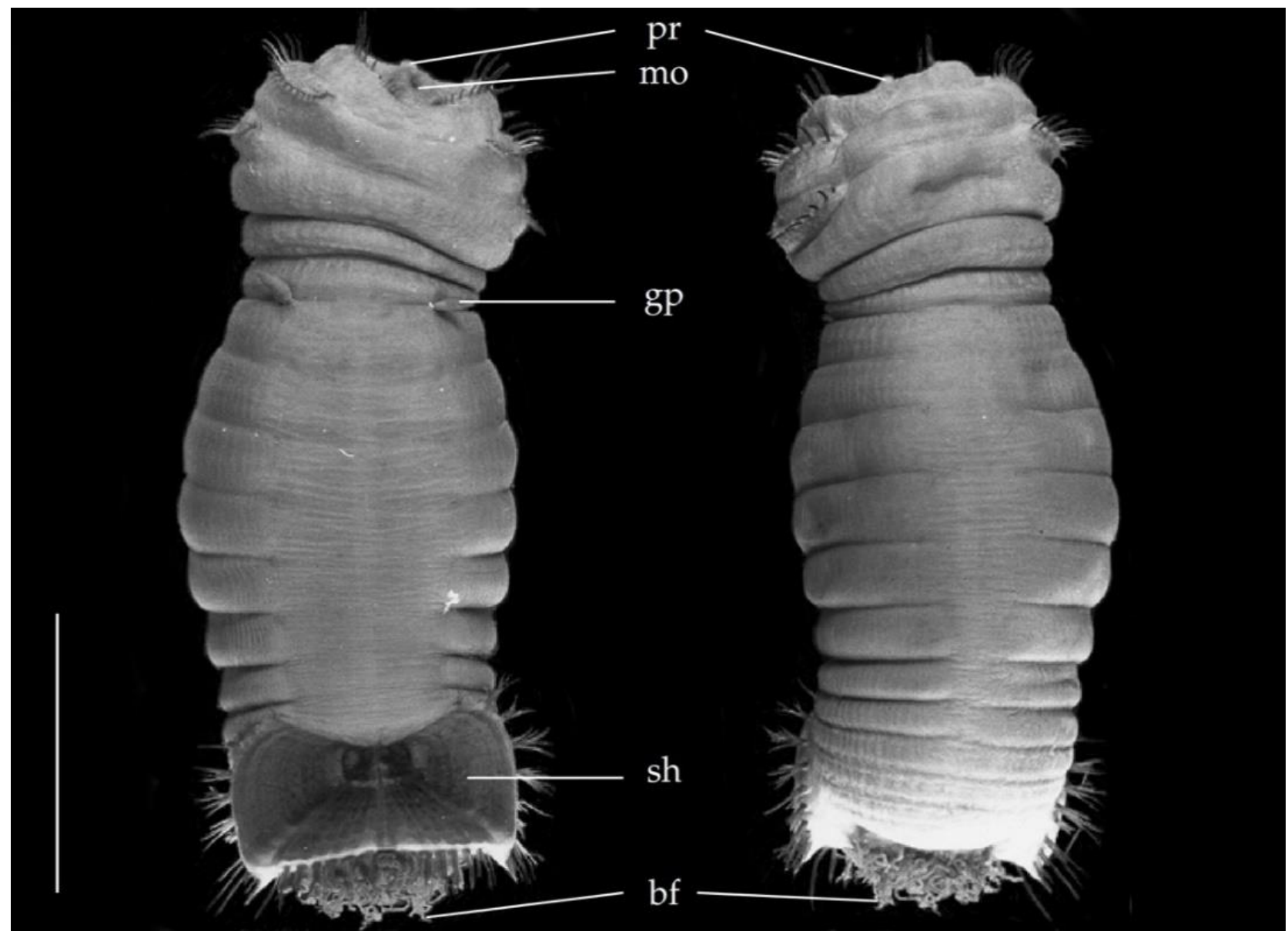

Figure 10. Sternaspis sp. Ventral (left) and dorsal (right) view. bf, branchial filament; gp, genital papillae; mo, mouth; pr, prostomium; sh, shield. Scale bar: $1 \mathrm{~cm}$. 


\subsection{Morphology}

Sternaspidae are relatively short-bodied worms, appearing grub- or peanut-shaped. The body colour is whitish to yellowish with the exception of a body maculated with numerous black spots in Sternaspis lindae Salazar-Vallejo, 2017 [246]. An anterior retractable region, including rows of strong hooks on segments $1-3$, can be completely withdrawn into the abdomen, resulting in an inflated ovoid body shape. In extended individuals, the following body regions can be distinguished: (1) an anterior introvert comprising prostomium, peristomium, and segments $1-5 / 6$; (2) a constricted region comprising segments $4-6$, and (3) an abdominal region.

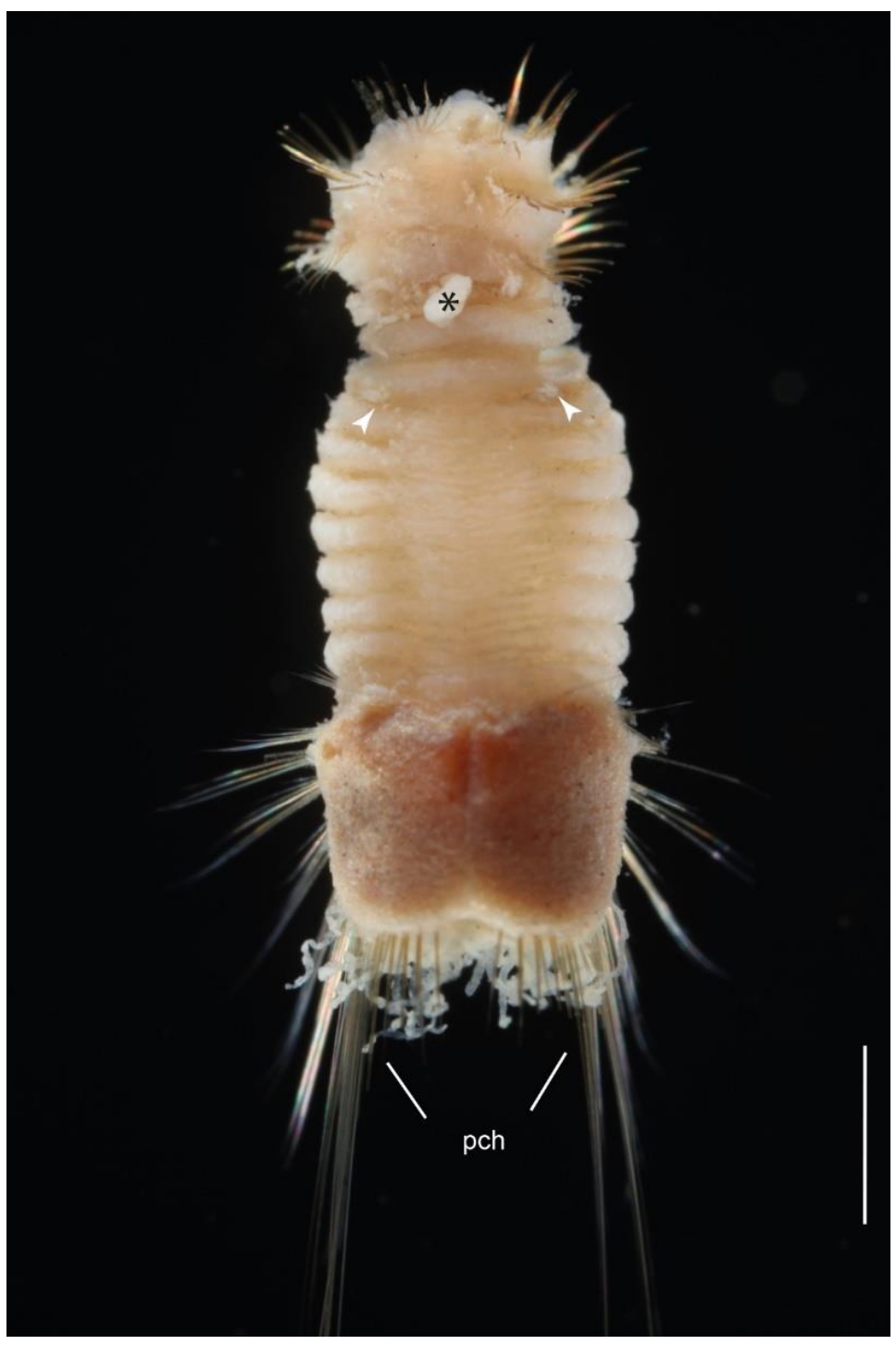

Figure 11. Mauretanaspis longichaeta. Holotype, MNHN-IA-TYPE 2005, ventral view; pch, posterior shield chaetae; * body damaged with oesophagus protruding; arrowheads point at gonopodial lobes. Scale bar: $1 \mathrm{~mm}$. Modified from Fiege and Barnich [247], licensed under CC BY 4.0.

The anterior end lacks appendages. The prostomium is a small, smooth hemispherical cupule, and the peristomium is reduced to a mound surrounding the mouth and is often at least partly covered by papillae. Eyes are absent, except perhaps in a juvenile specimen of S. fossor Stimpson, 1853 [248] from California [249]. Nuchal organs have not yet been identified with certainty.

The constricted region exhibits a pair of genital papillae protruding ventrally, usually from the intersegmental groove between segments 5 and 6 ( 7 and 8 if prostomium and 
peristomium are errouneously included in the counting). They often stay at least partly visible when the introvert is retracted.

The abdominal region consists of the segmented pre-shield region comprising 7 segments in Sternaspis Otto, 1821 [250] and Caulleryaspis Sendall and Salazar-Vallejo, 2013 [244] and 8 segments in Petersenaspis Sendall and Salazar-Vallejo, 2013 [244] and Mauretanaspis Fiege and Barnich, 2020 [247], as well as the posterior region bearing the ventral shield, and the dorsal branchial region with threadlike branchial filaments and filiform papillae originating from branchial cushions next to the anus. Segmentation is distinct along the body, though sometimes best visible laterally. Parapodia are reduced, i.e., parapodial lobes, appendages, and aciculae are absent. Morphological characters of the shield are of primary importance for species distinction. These characters include the shield's general shape, colour, surface sculpture (ribs, concentric rings), subdivisions and relative proportions, shape of the median suture, and presence/absence and firmness of attachment of sediment cover. Shields are stiff with loose sediment easily brushed off in all species of Sternaspis and Petersenaspis, but soft in Caulleryaspis with sediment firmly adherent. In the latter case, the sediment cover obscures structures of the shield surface from observation. The stiffness of the shields can be tested by bending its margin [251], but as free margins are sometimes absent and rather merge into the epidermis, this character is not always easy to evaluate and therefore considered of limited value for generic distinction. The adherence of sediment to the ventrocaudal shield, i.e., "firmly adherent" (not removable) versus "loosely attached" (easily brushed off), appears more useful in diagnosing sternaspid genera in combination with other characters [247,252].

Total length and abdomen length have been examined as diagnostic characters, but retraction can prevent these measurements. Shield measurements have been performed on several species, in an attempt to find a relation with body length, with varying results showing no clear correlation $[253,254]$.

Segments 1-3 bear a single row of stout spinelike chaetae, increasing dorsally in length and thickness. Their shape (tapering or subdistally expanded), colour, number, relative size, and possibly the relative length of rows, and degree of spacing among spines in extended specimens are of systematic importance. However, they cannot be observed in retracted specimens. All remaining chaetae are simple capillaries, mainly situated along the margins of the shield in adult animals, with numerous lateral and a lower number of caudal fascicles with shorter capillaries. Chaetae in lateral and posterior fascicles might be covered by a feltlike sheath in some species $[31,245,252,255,256]$. Chaetae of lateral fascicles increase in length caudally, reaching about four times the body length in Mauretanaspis longichaeta Fiege and Barnich, 2020 [247]. Peg chaetae—a dense group of numerous short chaetae embedded in a fibrous matrix and covered by a common sheath [256] —are situated at the posterolateral corners of the shield in species of Sternaspis and some species of Caulleryaspis. They are absent in Petersenaspis and Mauretanaspis. If present, peg chaetae are often accompanied on the inner side towards the body midline by a few very thin capillary chaetae. However, they can be missing or present on only one side and are therefore of limited systematic value. For juveniles, chaetae have been reported in the anterior abdomen (pre-shield) segments, they are usually missing in adults probably due to abrasion. The chaetae surrounding the shield might be a useful character with regard to number of chaetal fascicles and respective number of individual chaetae. The lengths of posterior chaetae relative to the size of the shield as well as the arrangement of chaetae in lateral fascicles (e.g., Sternaspis affinis Stimpson, 1864 [257], see [252]) may be of systematic value and should be further explored.

The shape and distribution of different types of cuticular papillae that can be found in varying densities in different body regions, including the ventrocaudal shield [244], might also be informative for species distinction. They can best be found along intersegmental folds or at the anterior end. Last but not least, the shape of the branchial cushions might also be useful for species distinction $[31,244,245,249]$. However, sediment cover as well as abrasion can hamper the study of these characters. 
A pygidium is not clearly defined, and pygidial appendages are absent except for an eversible anal peduncle that has been described for Sternaspis costata von Marenzeller, 1879 [258] and S. papillosa Zhadan, Tzetlin, and Salazar-Vallejo, 2017 [256].

Sendall and Salazar-Vallejo [244] established morphological characters for species distinction, which led to a rapid increase in the number of species described. However, discrepancies between morphology and molecular results raised questions about the diagnostic power of morphological shield characters for sternaspid identification and points to a much more complex taxonomy comprising cryptic species and possibly the presence of widely distributed deep-water species. Considering the shield characters Kobayashi et al. [259] and Drennan et al. [252] suggested revising the systematic position of Caulleryaspis nuda Salazar-Vallejo and Buzhinskaja, 2013 [260] and possibly the validity of the genus per se because the original character combination, "soft shield with firmly adhered layer of sediment", for Caulleryaspis had later been emended by Salazar-Vallejo and Buzhinskaja [260] to incorporate species with "soft shields with loosely adhered layer of sediment", such as C. nuda, as well as species with "soft shields without sediment attached" such as C. villamari Salazar-Vallejo and Buzhinskaja, 2013 [260] and C. nana Zhadan, Tzetlin, and Salazar-Vallejo, 2017 [256].

Juvenile specimens of Sternaspidae can apparently not per se be distinguished by small body size because at least in some species individuals of only $2-8 \mathrm{~mm}$ length have been found with oocytes $[253,256,261]$. Following the assumption that gonopodial lobes are instrumental in releasing sexual products, their absence as observed in some small specimens of Mauretanaspis longichaeta might indicate that these specimens are indeed not yet sexually mature [247].

Typically, juvenile characters for Sternaspidae appear to be a more distinctive papillation of the body, including the surface of the ventrocaudal shield. Moreover, in small (juvenile) specimens, the shield has been described as generally thinner and less sclerotinized, shield margins and surface structures not well defined, but anterior keels more pronounced. With increasing body size, shield plates become less rounded and ribs more defined. Shield colour appears to become darker (Sternaspis williamsae [260]; S. sendalli [262]; S. chinensis, S. liui [263]; Caulleryaspis villamari [246]; S. radiata, S. spinosa [264]).

\subsection{Taxonomy and Phylogeny}

To date, 43 valid species of Sternaspidae are known to belong to four genera: Sternaspis (32 species), Caulleryaspis (5), Petersenaspis (5), and Mauretanaspis (1) [31,245,247]. Including the revision of Sendall and Salazar-Vallejo [244], 31 species were described during the past decade, more than doubling the number of known species [246,247,256,260,262-266] (Table 2; Figure 2F). A key to species of Sternaspis, Caulleryaspis and Petersenaspis is provided by Salazar-Vallejo [246] and a table of characters for distinction of genera by Fiege and Barnich [247].

Table 2. List of Sternaspidae species currently accepted.

\begin{tabular}{|c|c|c|c|}
\hline Species & Distribution & Depth (m) & Type Locality \\
\hline $\begin{array}{l}\text { Caulleryaspis fauchaldi } \\
\text { Salazar-Vallejo and Buzhinskaja, } \\
2013\end{array}$ & $\begin{array}{l}\text { NE Pacific, Oregon to Southern } \\
\text { California }\end{array}$ & $1387-2800$ & $\begin{array}{l}\text { Oregon, Cascadia Abyssal Plain, } \\
\mathrm{W} \text { of Yaquina Bay, } 44^{\circ} 30.0^{\prime} \mathrm{N}, \\
125^{\circ} 34.0^{\prime} \mathrm{W} \text { to } 44^{\circ} 39.0^{\prime} \mathrm{N}, \\
125^{\circ} 33.2^{\prime} \mathrm{W}, 2800 \mathrm{~m}\end{array}$ \\
\hline $\begin{array}{l}\text { Caulleryaspis gudmundssoni } \\
\text { Sendall and Salazar-Vallejo, } 2013\end{array}$ & N Atlantic, Iceland & $452-1207$ & $\begin{array}{l}\text { Iceland, southeast of } \\
\text { Vestmannaey jar, } 63^{\circ} 02.30^{\prime} \mathrm{N} \text {, } \\
21^{\circ} 50.80^{\prime} \mathrm{W}, 1072 \mathrm{~m}\end{array}$ \\
\hline $\begin{array}{l}\text { Caulleryaspis laevis } \\
\text { (Caullery, 1944) }\end{array}$ & $\begin{array}{l}\text { Andaman Sea to South China } \\
\text { Sea, Southeastern Australia }\end{array}$ & 39-147 & $\begin{array}{l}\text { Sumbawa Island, Bay of Bima, } \\
08^{\circ} 27.5^{\prime} \mathrm{S}, 118^{\circ} 43.5^{\prime} \mathrm{E}, 55 \mathrm{~m}\end{array}$ \\
\hline
\end{tabular}


Table 2. Cont.

\begin{tabular}{|c|c|c|c|}
\hline Species & Distribution & Depth (m) & Type Locality \\
\hline $\begin{array}{l}\text { Caulleryaspis nuda } \\
\text { Salazar-Vallejo and Buzhinskaja, } \\
2013\end{array}$ & $\begin{array}{l}\text { NE Pacific, off Oregon } \\
\text { NW Pacific, Sea of Okhotsk, off } \\
\text { Kuril Islands as C. nuda }\end{array}$ & 2519 & $\begin{array}{l}\text { Off Oregon, } 48^{\circ} 9.0^{\prime} \mathrm{N}, 127^{\circ} 4.2^{\prime} \\
\mathrm{W}, 2519 \mathrm{~m}\end{array}$ \\
\hline $\begin{array}{l}\text { Caulleryaspis villamari } \\
\text { Salazar-Vallejo, } 2017\end{array}$ & E Pacific, off northern Peru & 160 & $\begin{array}{l}\text { Peru, off Isla Lobos de Tierra, } \\
06^{\circ} 27^{\prime} \mathrm{S}, 80^{\circ} 56^{\prime} \mathrm{W} \text { to } 06^{\circ} 23^{\prime} \mathrm{S}, \\
80^{\circ} 55^{\prime} \mathrm{W}, 160 \mathrm{~m}\end{array}$ \\
\hline $\begin{array}{l}\text { Mauretanaspis longichaeta } \\
\text { Fiege and Barnich, } 2020\end{array}$ & $\begin{array}{l}\text { CE and SE Atlantic, off } \\
\text { Mauritania and Angola }\end{array}$ & $2700-4400$ & $\begin{array}{l}\text { Off Mauretania; } 18^{\circ} 21.27^{\prime} \mathrm{N}, \\
17^{\circ} 57.44^{\prime} \mathrm{W} ; 2712 \mathrm{~m}\end{array}$ \\
\hline $\begin{array}{l}\text { Petersenaspis capillata } \\
\text { (Nonato, 1966) }\end{array}$ & SW Atlantic, Brazil & (intertidal) 52-138 & $\begin{array}{l}\text { Brazil, Vitoria Island, } 23^{\circ} 45^{\prime} 18^{\prime \prime} \\
\mathrm{S}, 44^{\circ} 00^{\prime} 54^{\prime \prime} \mathrm{W}, 52 \mathrm{~m}\end{array}$ \\
\hline $\begin{array}{l}\text { Petersenaspis deani } \\
\text { Salazar-Vallejo, } 2017\end{array}$ & E Pacific, Costa Rica & 22 & $\begin{array}{l}\text { Costa Rica, Golfo de Nicoya, } \\
09^{\circ} 44^{\prime} 00^{\prime \prime} \mathrm{N}, 84^{\circ} 59^{\prime} 25^{\prime \prime} \mathrm{W}, 22 \mathrm{~m}\end{array}$ \\
\hline $\begin{array}{l}\text { Petersenaspis harrisae } \\
\text { Salazar-Vallejo, } 2017\end{array}$ & $\begin{array}{l}\text { SW Indian Ocean, between } \\
\text { South Africa and Madagascar }\end{array}$ & $15-128$ & $\begin{array}{l}\text { South Africa, off Durban, } 29^{\circ} 11^{\prime} \\
\mathrm{S}, 31^{\circ} 37^{\prime} \mathrm{E}, 15 \mathrm{~m}\end{array}$ \\
\hline $\begin{array}{l}\text { Petersenaspis palpallatoci } \\
\text { Sendall and Salazar-Vallejo, } 2013\end{array}$ & Philippine Islands to Malaysia & $5.5-93$ & $\begin{array}{l}\text { Philippine Islands, Sibuyan Sea, } \\
\text { E off Kalibo, } 11^{\circ} 42.6^{\prime} \mathrm{N}, \\
122^{\circ} 31.5^{\prime} \mathrm{E}, 93 \mathrm{~m}\end{array}$ \\
\hline $\begin{array}{l}\text { Petersenaspis salazari } \\
\mathrm{Wu} \text { and } \mathrm{Xu}, 2017\end{array}$ & Northern South China Sea & 174-182 & $\begin{array}{l}\text { South China Sea, } 19^{\circ} 30^{\prime} \mathrm{N}, \\
112^{\circ} 30^{\prime} \mathrm{E}, 174 \mathrm{~m}\end{array}$ \\
\hline $\begin{array}{l}\text { Sternaspis affinis } \\
\text { Stimpson, } 1864\end{array}$ & $\begin{array}{l}\text { NE Pacific Ocean, Alaska to } \\
\text { Gulf of California }\end{array}$ & 95-154 & $\begin{array}{l}\text { Canada, British Columbia, Strait } \\
\text { of Georgia }\end{array}$ \\
\hline $\begin{array}{l}\text { Sternaspis Africana } \\
\text { Augener, } 1918\end{array}$ & $\begin{array}{l}\text { E Atlantic, W African coast from } \\
\text { Ghana to Angola }\end{array}$ & $20-70$ & Angola, St. Paul Loanda \\
\hline $\begin{array}{l}\text { Sternaspis andamanensis } \\
\text { Sendall and Salazar-Vallejo, } 2013\end{array}$ & $\begin{array}{l}\text { Indian Ocean, Andaman Sea } \\
\text { and Malaysia, South China Sea }\end{array}$ & $5-45$ & Andaman Sea, Thailand, $45 \mathrm{~m}$ \\
\hline $\begin{array}{l}\text { Sternaspis annenkovae } \\
\text { Salazar-Vallejo and Buzhinskaja, } \\
2013\end{array}$ & $\begin{array}{l}\text { NW Pacific, east of northern } \\
\text { Kuril I lands } \\
\text { SW Pacific, Australia, off E } \\
\text { Gippsland }\end{array}$ & $3980-4070$ & $\begin{array}{l}\text { East of northern Kuril Island, } \\
49^{\circ} 46^{\prime} 01^{\prime \prime} \mathrm{N}, 157^{\circ} 48^{\prime} 06^{\prime \prime} \mathrm{E}, \\
3980-4070 \mathrm{~m}\end{array}$ \\
\hline $\begin{array}{l}\text { Sternaspis britayevi } \\
\text { Zhadan, Tzetlin and } \\
\text { Salazar-Vallejo, } 2017\end{array}$ & South China Sea, Gulf of Tonkin & 65 & $\begin{array}{l}\text { South China Sea, Gulf of Tonkin, } \\
19^{\circ} 16^{\prime} \mathrm{N}, 107^{\circ} 19^{\prime} \mathrm{E}, 65 \mathrm{~m}\end{array}$ \\
\hline $\begin{array}{l}\text { Sternaspis buzhinskajae } \\
\text { Salazar-Vallejo, } 2014\end{array}$ & $\begin{array}{l}\text { Arctic Ocean, Okhotsk, Chukchi, } \\
\text { Bering and Beaufort Seas }\end{array}$ & $3.5-90$ & $\begin{array}{l}\text { Alaska, Beaufort Sea, off Point } \\
\text { Barrow, 3.5-5.0 m }\end{array}$ \\
\hline $\begin{array}{l}\text { Sternaspis chilensis } \\
\text { Díaz-Díaz and Rozbaczylo, } 2017\end{array}$ & $\begin{array}{l}\text { SE Pacific, Austral Chilean } \\
\text { channel and fjord region }\end{array}$ & $50-515$ & $\begin{array}{l}\text { Chile, Magellan Province, } \\
\text { Moraleda Channel, } 45^{\circ} 06^{\prime} \mathrm{S} \text {, } \\
73^{\circ} 38^{\prime} \mathrm{W}, 250 \mathrm{~m}\end{array}$ \\
\hline $\begin{array}{l}\text { Sternaspis chinensis } \\
\text { Wu, Salazar-Vallejo and } \mathrm{Xu}, 2015\end{array}$ & $\begin{array}{l}\text { Yellow and East China Sea, } \\
\text { Bohai Sea }\end{array}$ & $\begin{array}{c}8-63.7 \\
500\end{array}$ & $\begin{array}{l}\text { Bohai Sea, } 38^{\circ} 38^{\prime} \mathrm{N}, 120^{\circ} 23^{\prime} \mathrm{E}, \\
39 \mathrm{~m}\end{array}$ \\
\hline $\begin{array}{l}\text { Sternaspis costata } \\
\text { von Marenzeller, } 1879\end{array}$ & $\begin{array}{l}\text { NW Pacific, Southern Sakhalin } \\
\text { Island to Philippines, South } \\
\text { China Sea }\end{array}$ & $15-70$ & $\begin{array}{l}\text { Japan, Honshu Island, Chiba, } \\
\text { Boso Peninsula }\end{array}$ \\
\hline $\begin{array}{l}\text { Sternaspis fossor } \\
\text { Stimpson, } 1853\end{array}$ & $\begin{array}{l}\text { NW Atlantic, Canada to } \\
\text { northeastern United States }\end{array}$ & $20-153$ & $\begin{array}{l}\text { Canada, Nova Scotia, } 88 \text { km E } \\
\text { Cape Sable, } 153 \mathrm{~m}\end{array}$ \\
\hline $\begin{array}{l}\text { Sternaspis islandica } \\
\text { Malmgren, } 1867\end{array}$ & $\begin{array}{l}\text { NE Atlantic, Norwegian Sea, } \\
\text { Iceland and Faroe Islands }\end{array}$ & $7-226$ & $\begin{array}{l}\text { Iceland, Berufjord, } 64^{\circ} 48^{\prime} \mathrm{N}, \\
14^{\circ} 30^{\prime} \mathrm{W}, 27-55 \mathrm{~m}\end{array}$ \\
\hline $\begin{array}{l}\text { Sternaspis lindae } \\
\text { Salazar-Vallejo, } 2017\end{array}$ & $\begin{array}{l}\text { E Pacific, Gulf of Panama to NW } \\
\text { Colombia }\end{array}$ & $119-275$ & $\begin{array}{l}\text { Panama, } 08^{\circ} 39.3^{\prime} \mathrm{N}, 79^{\circ} 31.7^{\prime} \mathrm{W}, \\
22-27 \mathrm{~m}\end{array}$ \\
\hline $\begin{array}{l}\text { Sternaspis liui } \\
\text { Wu, Salazar-Vallejo and Xu, } 2015\end{array}$ & Yellow Sea & $21-43.3$ & $\begin{array}{l}\text { Yellow Sea, } 35^{\circ} 59^{\prime} \mathrm{N}, 122^{\circ} 00^{\prime} \mathrm{E} \text {; } \\
43.3 \mathrm{~m}\end{array}$ \\
\hline
\end{tabular}


Table 2. Cont.

\begin{tabular}{|c|c|c|c|}
\hline Species & Distribution & Depth (m) & Type Locality \\
\hline $\begin{array}{l}\text { Sternaspis londognoi } \\
\text { Salazar-Vallejo, } 2017\end{array}$ & $\begin{array}{l}\text { Gulf of Mexico and Caribbean } \\
\text { Sea }\end{array}$ & intertidal-344 & $\begin{array}{l}\text { SW Caribbean, Panama, } \\
\text { Caledonia Bay, intertidal }\end{array}$ \\
\hline $\begin{array}{l}\text { Sternaspis maior } \\
\text { Chamberlin, } 1919\end{array}$ & $\begin{array}{l}\text { E Pacific, Central Gulf of } \\
\text { California }\end{array}$ & 180-1158 & $\begin{array}{l}\text { Gulf of California, Sinaloa, Off } \\
\text { Isla Altamura, } 24^{\circ} 52^{\prime} \mathrm{N}, 108^{\circ} 58^{\prime} \\
\mathrm{W}, 830 \mathrm{~m}\end{array}$ \\
\hline $\begin{array}{l}\text { Sternaspis maureri } \\
\text { Salazar-Vallejo and Buzhinskaja, } \\
2013\end{array}$ & E Pacific and SW Pacific & $795-6489$ & $\begin{array}{l}\text { Peru, W of Trujillo, } 08^{\circ} 16^{\prime} \mathrm{S}, \\
81^{\circ} 05^{\prime} \mathrm{W}, 6156-6489 \mathrm{~m}\end{array}$ \\
\hline $\begin{array}{l}\text { Sternaspis nana } \\
\text { Zhadan, Tzetlin and } \\
\text { Salazar-Vallejo, } 2017\end{array}$ & $\begin{array}{l}\text { Vietnam, Nha Trang Bay, South } \\
\text { China Sea }\end{array}$ & $15-40$ & $\begin{array}{l}\text { South China Sea, Nha Trang } \\
\text { Bay, } 12^{\circ} 11^{\prime} 50^{\prime \prime} \mathrm{N}, 109^{\circ} 15^{\prime} 06.6^{\prime \prime} \\
\text { E, } 23 \mathrm{~m}\end{array}$ \\
\hline $\begin{array}{l}\text { Sternaspis papillosa } \\
\text { Zhadan, Tzetlin and } \\
\text { Salazar-Vallejo, } 2017\end{array}$ & $\begin{array}{l}\text { Vietnam, Nha Trang Bay, South } \\
\text { China Sea }\end{array}$ & $11-40$ & $\begin{array}{l}\text { South China Sea, Nha Trang } \\
\text { Bay, } 12^{\circ} 10^{\prime} 24^{\prime \prime} \mathrm{N}, 109^{\circ} 15^{\prime} 42^{\prime \prime} \mathrm{E}, \\
21.1 \mathrm{~m}\end{array}$ \\
\hline $\begin{array}{l}\text { Sternaspis piotrowskiae } \\
\text { Salazar-Vallejo, } 2014\end{array}$ & Philippine Islands & $272-636$ & $\begin{array}{l}\text { Philippines, Luzon Island, } \\
\text { Balayan Bay, } 13.82^{\circ} \mathrm{N}, 120.75^{\circ} \mathrm{E} \text {, } \\
272-291 \mathrm{~m}\end{array}$ \\
\hline $\begin{array}{l}\text { Sternaspis princeps } \\
\text { Selenka, } 1885\end{array}$ & $\begin{array}{l}\text { SW Pacific, New Zealand, off } \\
\text { North Island }\end{array}$ & 1274 & $\begin{array}{l}\text { New Zealand, North Island, NE } \\
\text { off Gisborne, } 37^{\circ} 34^{\prime} \mathrm{S}, 179^{\circ} 22^{\prime} \mathrm{E}, \\
1274 \mathrm{~m}\end{array}$ \\
\hline $\begin{array}{l}\text { Sternaspis radiate } \\
\mathrm{Wu} \text { and } \mathrm{Xu}, 2017\end{array}$ & Northern South China Sea & 16-105.5 & $\begin{array}{l}\text { South China Sea } 22^{\circ} 15^{\prime} \mathrm{N}, \\
115^{\circ} 00^{\prime} \mathrm{E}, 41 \mathrm{~m}\end{array}$ \\
\hline $\begin{array}{l}\text { Sternaspis rietschi } \\
\text { Caullery, } 1944\end{array}$ & $\begin{array}{l}\text { Arafura Sea, Indonesia, off } \\
\text { Wokam Island }\end{array}$ & 1788 & $\begin{array}{l}\text { Indonesia, } \mathrm{W} \text { of Wokam Island, } \\
5^{\circ} 46^{\prime} \mathrm{S}, 134^{\circ} 00^{\prime} \mathrm{E}, 1788 \mathrm{~m}\end{array}$ \\
\hline $\begin{array}{l}\text { Sternaspis scutata } \\
\text { (Renier in Ranzani, 1817) }\end{array}$ & Mediterranean Sea & $9-36$ & $\begin{array}{l}\text { Aegean Sea, Izmir Bay, } 38^{\circ} 30^{\prime} 00^{\prime \prime} \\
\mathrm{N}, 26^{\circ} 50^{\prime} 00^{\prime \prime} \mathrm{E}, 33 \mathrm{~m}\end{array}$ \\
\hline $\begin{array}{l}\text { Sternaspis sendalli } \\
\text { Salazar-Vallejo, } 2014 \text { incl. S. } \\
\text { monroi Salazar-Vallejo, } 2014\end{array}$ & $\begin{array}{l}\text { Southern Ocean, South Georgia } \\
\text { to Antarctic Peninsula and } \\
\text { Weddell Sea }\end{array}$ & $160-1500$ & South Orkneys, Scotia Sea \\
\hline $\begin{array}{l}\text { Sternaspis sherlockae } \\
\text { Salazar-Vallejo, } 2017\end{array}$ & Red Sea & $\begin{array}{l}\text { Presumed shallow } \\
\text { water }\end{array}$ & Red Sea \\
\hline $\begin{array}{l}\text { Sternaspis spinosa } \\
\text { Sluiter, } 1882\end{array}$ & $\begin{array}{l}\text { W Pacific from South China Sea } \\
\text { to Andaman Sea and Coral Sea } \\
\text { off Australia }\end{array}$ & $7-110$ & $\begin{array}{l}\text { Indonesia, Java, Bay of Batavia, } \\
\text { "Batavia Roads", outside } \\
\text { Jakarta, } 30 \mathrm{~m}\end{array}$ \\
\hline $\begin{array}{l}\text { Sternaspis sunae } \\
\mathrm{Wu} \text { and } \mathrm{Xu}, 2017\end{array}$ & South China Sea & 224 & $\begin{array}{l}\text { South China Sea, Nansha } \\
\text { Islands, } 224 \mathrm{~m}\end{array}$ \\
\hline $\begin{array}{l}\text { Sternaspis thalassemoides } \\
\text { Otto, } 1821\end{array}$ & $\begin{array}{l}\text { NE Atlantic and Mediterranean } \\
\text { Sea }\end{array}$ & n.d. & Tyrrhenian Sea, Naples \\
\hline $\begin{array}{l}\text { Sternaspis thorsoni } \\
\text { Sendall and Salazar-Vallejo, } 2013\end{array}$ & $\begin{array}{l}\text { Indian Ocean, Arabian/Iranian } \\
\text { Gulf to Andaman Sea }\end{array}$ & $3-110$ & $\begin{array}{l}\text { Gulf of Oman, off Jask, } 25^{\circ} 45^{\prime} \mathrm{N}, \\
57^{\circ} 12^{\prime} \mathrm{E}, 110 \mathrm{~m}\end{array}$ \\
\hline $\begin{array}{l}\text { Sternaspis uschakovi } \\
\text { Salazar-Vallejo and Buzhinskaja, } \\
2013\end{array}$ & $\begin{array}{l}\text { NW and E Pacific, Okhotsk Sea, } \\
\text { California, Gulf of California, W } \\
\text { Mexico }\end{array}$ & $592-2548$ & $\begin{array}{l}\text { Okhotsk Sea, } 55^{\circ} 13^{\prime} \mathrm{N}, 146^{\circ} 52^{\prime} \\
\mathrm{E}, 592 \mathrm{~m}\end{array}$ \\
\hline $\begin{array}{l}\text { Sternaspis williamsae } \\
\text { Salazar-Vallejo and Buzhinskaja, } \\
2013\end{array}$ & $\begin{array}{l}\text { NE Pacific, Oregon to California } \\
\text { NW Pacific, off Kuril Islands as } \\
\text { S. cf. williamsae }\end{array}$ & $1000-2800$ & $\begin{array}{l}\text { Oregon, } \mathrm{W} \text { of Yaquina Bay, } \\
44^{\circ} 30.0^{\prime} \mathrm{N}, 125^{\circ} 34.0^{\prime} \mathrm{W} \text { to } \\
44^{\circ} 39.0^{\prime} \mathrm{N}, 125^{\circ} 33.2^{\prime} \mathrm{W}, 2800 \mathrm{~m}\end{array}$ \\
\hline $\begin{array}{l}\text { Sternaspis wui } \\
\mathrm{Wu} \text { and } \mathrm{Xu}, 2017\end{array}$ & Northern South China Sea & $173-230$ & $\begin{array}{l}\text { South China Sea, } 17^{\circ} 45^{\prime} \mathrm{N}, \\
110^{\circ} 30^{\prime} \mathrm{E}, 230 \mathrm{~m}\end{array}$ \\
\hline
\end{tabular}


For better resolution of sternaspid systematics, more comprehensive molecular data for more species would be desirable to complement known characters and suitably treated material needs to be collected. As a first example using next generation sequencing (NGS) techniques, the complete mitochondrial genome of specimens identified as Sternaspis scutata Renier in Ranzani, 1817 [267] collected from Jiazhou Bay, near Qingdao (Yellow Sea), was sequenced [268].

\subsection{Biogeography}

Most sternaspid species have been recorded from low intertidal to shelf depths (200 m), but 14 have been found between $200 \mathrm{~m}$ and $6500 \mathrm{~m}$ deep (Table 3). The majority of species occurs in the Pacific (29 species), nine are recorded for the Atlantic, eight for the wider Indian Ocean, and only two and one for the Arctic and the Antarctic Ocean, respectively (Table 4, Figure 3F). The South China Sea has been found to be an area of high sternaspid diversity with 11 species reported, followed by the central eastern Pacific with nine species recorded. For the northwestern Pacific, with four species currently recorded, five distinct but yet undescribed species might have to be added due to recent molecular studies [252, 259]. Among the species occurring in the Atlantic and its neighbouring seas, there are two species recorded in the Mediterranean Sea and two or possibly three species in the North-East Atlantic. Six species are widely recorded from the Indian Ocean and one species each in the Arabian/Persian Gulf and the Red Sea. Maps showing the type localities of known species were provided by Fiege [31,245], Díaz-Díaz and Rozbaczylo [265], and Drennan et al. [252].

Table 3. Deep-water Sternaspidae (predominantly recorded deeper than $200 \mathrm{~m}$; Sternaspis chinensis Wu, Salazar-Vallejo and $\mathrm{Xu}, 2015$ [263] is not included as only a single record from $500 \mathrm{~m}$ exists [252]).

\begin{tabular}{llc}
\hline \multicolumn{1}{c}{ Species } & \multicolumn{1}{c}{ Distribution } & Depth (m) \\
\hline Caulleryaspis fauchaldi Salazar-Vallejo and Buzhinskaja, 2013 & NE Pacific, Oregon to Southern California & $1387-2800$ \\
Caulleryaspis gudmundssoni Sendall and Salazar-Vallejo, 2013 & North Atlantic, Iceland & $452-1207$ \\
Caulleryaspis nuda Salazar-Vallejo and Buzhinskaja, 2013 & NE Pacific, off Oregon & 2519 \\
Mauretanaspis longichaeta Fiege and Barnich, 2020 & CE and SE Atlantic, off Mauritania and Angola & $2700-4400$ \\
Sternaspis annenkovae Salazar-Vallejo and Buzhinskaja, 2013 & NW Pacific, east of northern Kurile Island & $3980-4070$ \\
Sternaspis chilensis Díaz-Díaz and Rozbaczylo, 2017 & SE Pacific, Austral Chilean channel and fjord & region \\
Sternaspis maior Chamberlin, 1919 & E Pacific, Central Gulf of California & $180-1158$ \\
Sternaspis maureri Salazar-Vallejo and Buzhinskaja, 2013 & E and SW Pacific & $795-6489$ \\
Sternaspis piotrowskiae Salazar-Vallejo, 2014 & Philippine Islands & $272-636$ \\
Sternaspis princeps Selenka, 1885 & SW Pacific, New Zealand & 1274 \\
Sternaspis rietschi Caullery, 1944 & Arafura Sea, off Wokam Island & 1788 \\
Sternaspis sendalli Salazar-Vallejo, 2014 & Southern Ocean and Antarctic Peninsula & $160-1500$ \\
Sternaspis uschakovi Salazar-Vallejo and Buzhinskaja, 2013 & N Pacific, Okhotsk Sea, California, Gulf of & California \\
Sternaspis williamsae Salazar-Vallejo and Buzhinskaja, 2013 & NE Pacific, Oregon to California & $592-2548$ \\
\hline
\end{tabular}

The distributional range varies greatly among species, and if genetic data are considered besides morphological distinctness, the picture becomes even more complex. It appears that narrow distribution ranges are found in shallow-water species, while some deep-water species inhabit much larger areas [252], e.g., nine species are known only from their respective type locality (Table 2). Seven species (Petersenaspis salazari Wu and Xu, 2017 [264], Sternaspis britayevi Zhadan, Tzetlin, and Salazar-Vallejo, 2017 [256], S. nana, S. papillosa, S. radiata $\mathrm{Wu}$ and $\mathrm{Xu}, 2017$ [264], S. sunae $\mathrm{Wu}$ and $\mathrm{Xu}, 2017$ [264], and S. wui Wu and $\mathrm{Xu}, 2017$ [264]) described from the South China Sea are known only from this area. Some species overlap in distribution, e.g., adults of $S$. nana and juveniles of S. papillosa were found close together in Nha Trang Bay, South China Sea [238]. Sternaspis monroi Salazar-Vallejo, 2014 [262] and S. sendalli have both been described from close localities off the South Orkney Islands in the Scotia Sea [262] and were recently found synonymous 
due to morphological and genetical studies [252]. Caulleryaspis fauchaldi Salazar-Vallejo and Buzhinskaja, 2013 [260] and S. williamsae Salazar-Vallejo and Buzhinskaja, 2013 [260] have been described from the same sample, off Oregon (NE Pacific) [260].

Table 4. Geographic distribution of sternaspid species including some putative records of Sternaspis scutata (bold: species known only from type locality; underlined: species known predominantly from deep water; depth >> 200 m; possible but unconfirmed records of $S$. scutata are preceded by a question mark).

\begin{tabular}{|c|c|c|}
\hline Geographic Distribution & No. of Species & Species \\
\hline Arctic Ocean & 2 & S. bushinskajae, S. fossor \\
\hline Pacific & 29 & \\
\hline NE Pacific & 5 & C. fauchaldi, C. nuda, S. affinis, S. uschakovi, $\underline{\text { S. williamsae }}$ \\
\hline NW Pacific & $4(+5)$ & $\begin{array}{l}\text { S. annenkovae, S. bushinskajae, S. costata, S. uschakovi, }(+\underline{\text { C. cf. nuda, }} \\
\underline{\text { S. cf. williamsae, and } 3 \text { unidentified species of Sternaspis; see [259] and [252] }}\end{array}$ \\
\hline CE Pacific & 9 & $\begin{array}{l}\text { C. fauchaldi, C. villamari, P. deani, S. affinis, S. lindae, S. maior, S. maureri, } \\
\text { S. uschakovi, S. williamsae }\end{array}$ \\
\hline CW Pacific & 3 & P. palpallatoci, S. costata, S. piotrowskiae \\
\hline \multicolumn{3}{|l|}{ W Pacific } \\
\hline $\begin{array}{l}\text { E China Sea, } \\
\text { Yellow Sea }\end{array}$ & 2 & S. chinensis, S. liui, (+? S. scutata in Jiaozhou Bay, see Wang et al. [268]) \\
\hline South China Sea & 11 & $\begin{array}{l}\text { C. laevis, P. salazari, S. andamanensis, S. britayevi, S. costata, S. nana, S. papillosa, } \\
\text { S. radiata, S. spinosa, S. sunae, S. wui, }\end{array}$ \\
\hline SW Pacific & 5 & C. laevis, $\underline{\text { S. annenkovae, }}$ S. maureri, S. princeps, S. spinosa \\
\hline SE Pacific & 1 & $\underline{\text { S. chilensis }}$ \\
\hline Atlantic & 9 & \\
\hline NE Atlantic & $2(+1)$ & C. gudmundssoni, S. islandica, (+ S. cf. scutata in English Channel; see [252]) \\
\hline $\begin{array}{l}\text { Mediterranean } \\
\text { Sea }\end{array}$ & 2 & S. scutata, S. thalassemoides \\
\hline NW Atlantic & 1 & S. fossor \\
\hline CE Atlantic & 2 & M. longichaeta, S. africana \\
\hline \multicolumn{3}{|l|}{ CW Atlantic } \\
\hline Gulf of Mexico & 1 & S. londognoi \\
\hline SW Atlantic & 1 & P. capillata \\
\hline SE Atlantic & 2 & M. longichaeta, S. africana \\
\hline Indian Ocean & 8 & \\
\hline Indian Ocean & 6 & $\begin{array}{l}\text { C. laevis, P. palpallatoci, S. andamanensis, S. rietschi, S. spinosa, S. thorsoni, (+? S. } \\
\text { scutata in Sundarban Mangroves, Gulf of Bengal, see [269], Cochin Estuary, SW } \\
\text { India, see [270]; West coast of India, see [271]) }\end{array}$ \\
\hline \multicolumn{3}{|l|}{ NW Indian Ocean } \\
\hline $\begin{array}{l}\text { Arabian/Persian } \\
\text { Gulf; Gulf of Oman }\end{array}$ & 1 & S. thorsoni \\
\hline Red Sea & 1 & S. sherlockae, (+? S. scutata Gulf of Suez; see [272]) \\
\hline SW Indian Ocean & 1 & P. harrisae \\
\hline Antarctic Ocean & 1 & S. sendalli \\
\hline
\end{tabular}

On the other hand, phylogeographic studies using mitochondrial and nuclear genes revealed examples of low genetic differences over large distances, e.g., $1500 \mathrm{~km}$ among populations from lower bathyal to abyssal depths in the NW Pacific for Sternaspis sp. cf. 
S. williamsae [259]. Low genetic variation was also found among populations of Sternaspis affinis over a geographic distance of $1800 \mathrm{~km}$ along the west coast of North America (Washington to California), raising the question of only this single species being present in this area. Genetic data also show close relationships among specimens of Sternaspis cf. sp. S. annenkovae from off SE Australia with a clade of Sternaspis sp. cf. S. williamsae and Sternaspis sp. cf. S. nuda in the NW Pacific covering a distance of about $9600 \mathrm{~km}$ across the Pacific Ocean [252]. Sternaspis scutata is apparently the most widely reported name in the past but was recorded also more recently from the Cochin Estuary (SW India) [270], the English Channel [273], where it was considered an invasive species, the west coast of India (Arabian Sea) [271], the Sundarban Mangroves (Bengal Sea) [269], Jiaouzhou Bay (Yellow Sea) [268,274], and the Gulf of Suez (Red Sea) [272]. The latter record could be the result of Anti-Lessepsian migration, i.e., Mediterranean species entering the Red Sea via the Suez Canal [275]. Due to this wide geographic range of records far away from the type locality, it seems likely that cryptic or undescribed species are present, which need to be distinguished [259]. Molecular data support morphological observations regarding the genetic distinctness of Sternaspis sp. cf. S. scutata reported from the English Channel, from S. scutata present in the Mediterranean and a molecular record from the Bay of Biscay (North East Atlantic), which was found to be the first record of S. scutata outside the Mediterranean. Other records of sternaspids identified as S. scutata in GenBank from the Bering Sea, the Bay of Bengal, and Southern Chile were shown to be different from each other and from Mediterranean S. scutata, lending further support against assumptions of a wide distribution of S. scutata outside the Mediterranean Sea [252].

Lecithotrophic larvae have been observed for some sternaspid species, although with a rather short planktonic period. Cold temperatures in deep water might inhibit development of larvae and in combination with favourable currents it might result in a wide distribution in the deep sea. This hypothesis, however, requires confirmation by studies on reproduction. So far planktonic phases for sternaspid larvae have only been found to last for less than two days in shallow water among S. scutata [276].

\subsection{Biology and Ecology}

The biology and ecology of Sternaspidae is only poorly known. They live burrowing in the sediment, mostly in muddy bottoms, but have also been recorded from a variety of sediment types [244]. Individuals are reported to bury in the sediment head first, mostly with their dorsal side up, leaving the gills exposed at the sediment surface while the anterior part of the body is retracted [276,277]. Sternaspids are able to move quickly in the sediment by extending and retracting their introvert $[276,278,279]$, but they have also been found to stay in the same position for prolonged periods of time [73]. Sternaspids are usually not represented in samples in high numbers, but they can be locally abundant and dominant in benthic communities with up to $1335 \mathrm{spms} / \mathrm{m}^{2}$ [271]. They have been classified as microphagous subsurface deposit feeders [73] preferring particles of small size [280].

Sternaspids are gonochoristic and show no signs of sexual dimorphism. Year-round recruitment with a peak in summer and lecitotrophic larvae with a short planktonic phase (less than two days) have been observed [276,281].

\section{Discussion: Methods and Perspectives}

Rigorous implementation of diverse methods of morphological observation and their integration with molecular methods has played a major part in systematic understanding and biodiversity discovery in the families Acrocirridae, Cirratulidae, Cossuridae, Longosomatidae, Paraonidae, and Sternaspidae, e.g., refs. [32,93]. Continued rigour in morphological studies, cooperation, and further integration of molecular data will be key to resolving the current issues in diversity and systematics in these groups, such as the resolution of their classification and a unified terminology for morphological characters. 


\subsection{Washing Samples}

To accurately assess small benthic polychaete abundance and avoid the excessive fragmentation and loss of important diagnostic features, it is necessary to gently wash samples with sieves with fine mesh sizes not exceeding $500 \mu \mathrm{m} ; 150-300 \mu \mathrm{m}$ screens produce more accurate results (Figure 12); $500 \mu \mathrm{m}$ sieves are better suited for shelf samples, while in deep environments the use of 250-300 $\mu \mathrm{m}$ sieves is advisable. Sternaspid species have a stouter shape and are more robust polychaetes. Finer sieves also allow for retaining early developmental stages [83]. Ohwada [282] recommended preserving samples before washing to retain the maximum number of specimens. However, this can be problematic when processing large samples in ethanol for future DNA extraction, as care must be ensured to maintain a sufficient concentration of ethanol and a homogenization of the sample.

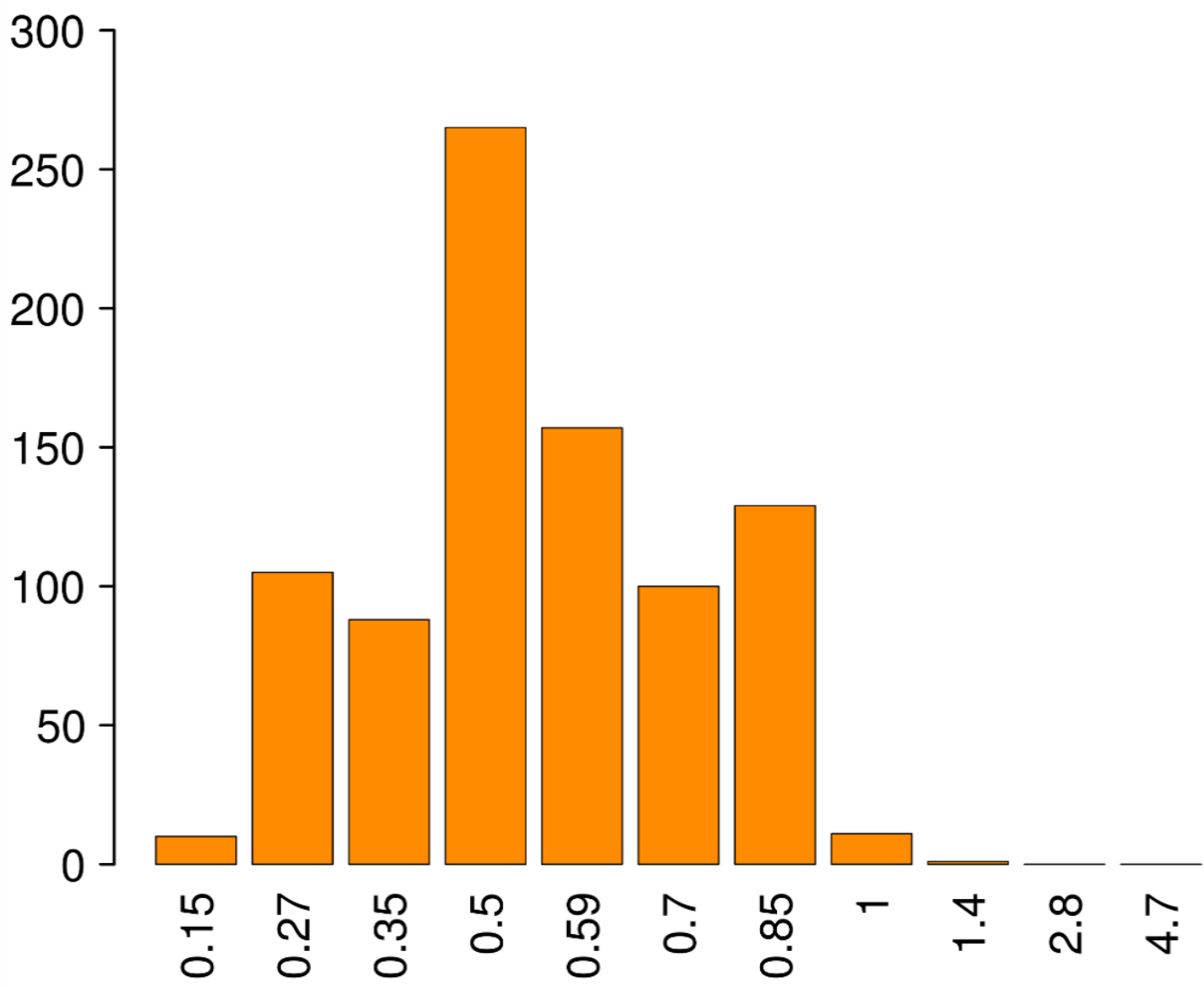

Figure 12. Diagram showing number of specimens of Cossura candida on sieves with different mesh sizes in mm (data obtained from [282] Table 1).

\subsection{Fixation}

Individuals used for DNA investigation should be ideally sorted alive and fixed in $96 \%$ ethanol and preserved at $-20{ }^{\circ} \mathrm{C}$ until DNA extraction. Bulk-fixed samples give a variable extraction and amplification success, based on the concentration of the ethanol and time elapsed between fixation and sorting. Samples fixed with $96 \%$ ethanol and stored in a cold room allow for obtaining useful genetic material up to at least 10 years after sampling, even if in old samples the amplification of nuclear markers might be difficult. Samples fixed with $70 \%$ ethanol are useful for genetics for a limited time and should be sorted and transferred to clean ethanol within a few months after sampling. Sample storage at cold, stable temperature allows for obtaining useful DNA extracts for a longer time. Samples fixed with denatured ethanol or stained with Rose Bengal to ease the sorting are unsuitable for genetics. 


\subsection{Species Description}

Ideally, species descriptions should include light microscopy and scanning electron microscopy, and molecular genetic investigation. Light microscopy should be used for dorsal and lateral view to display the shape of the prostomium and the thorax-abdomen transition (e.g., in Cossuridae), to display the location of the branchial filament(s), eventual palps/tentacles, and chaetal characteristics. Different kinds of staining are highly recommended for improving the visibility of morphological characteristics [283]. Molecular data are also very welcome, as integrative systematics is necessary to disentangle the diversity of most families, especially in the case of pseudocryptic species complexes, which are likely to be common [93]. Ecological preferences, such as depth, granulometry, and habitat type, are not strictly necessary for the description, but might be useful for parataxonomists in the identification of taxa, and might suggest the occurrence of cryptic species in the case of discrepancies. Biological features such as feeding, reproductive mode(s), and egg or larvae characteristics are in most cases difficult to obtain, but can also prove important in discriminating species and inferring phylogenetic hypotheses.

\subsubsection{Staining}

Methyl green and methylene blue are commonly used for polychaete systematics, and both produce similar results. These stains can be used for two purposes. First, for contrasting external structures, such as chaetae, parapodial lobes, papillae, head appendages, cirri, branchiae, and scars of these structures when they were lost. This method requires transferring worms to water before staining and examination in water. The concentration of water-soluble pigment is low for this method. Examples of methylene blue staining have been published previously $[136,145]$. Second, these stains can be used to stain glandular structures. For this, a saturated ethanol solution of dye is used, and worms are stained for some time, after which they are examined in clean ethanol after partial de-staining and differentiation. This method is especially useful for cossurids, as their staining patterns are species-specific, which accelerates mass identification, even for short anterior fragments [134]. This method is also often used for Cirratulidae species, but not so much in Longosomatidae, Acrocirridae or Paraonidae systematics as the majority of these taxa do not present any specific pattern. The exception to this is represented by members of Levinsenia, in Paraonidae, where the anterior part of the body shows a distinctive and often diagnostic staining pattern [223]. It has not yet been tested for members of Sternaspidae.

Shirlastain A is also a commonly used dye in polychaete systematics, e.g., ref. [284]. Its water solution makes external structures more distinguishable, similar to methylene blue. Shirlastain A can be used to highlight external structures, such as branchiae, prostomial antenna, and parapodial lobes, and to identify broken structures through their scars, making the examination and identification of individuals easier. It is also routinely used for members of Cirratulidae $[83,283]$.

\subsubsection{Scanning Electron Microscopy}

Scanning electron microscopy (SEM) illustrations are highly recommended for species descriptions to document the exact position of the branchial filament of cossurids or tentacles of cirratulids, and especially for illustrating chaetae, including their exact number, position, shape, length, and thickness $[57,98]$. They are also helpful in revealing broken branchiae by making the scars clearly visible. The preparation of the sample for SEM imaging, however, might lead to artefacts in the shape of the soft structures, and also the shape of chaetae should be carefully evaluated, as in recent descriptions, broken chaetae have been treated as entire and considered as diagnostic characters [221]. Dehydrating the specimens using a series of baths from $100 \% \mathrm{EtOH}$ to $100 \% \mathrm{HMDS}$ before air drying has been proposed as a gentler alternative to the most fragile specimens compared to critical point drying $[285,286]$. 


\subsection{Molecular Genetic Investigations}

This approach requires ethanol-preserved specimens and is extremely important for resolving systematic and phylogenetic problems. It is recommended to target several genetic markers, both mitochondrial and nuclear $[4,287]$. For exact species identification, reference sequences from the type locality of each species are desired, and at higher taxonomic levels, sequences from type localities of at least the type species are wanted.

DNA barcoding of Cirratulidae and Ctenodrilidae has proven relatively easy, and the use of molecular data to study this group is increasing. The markers COI, 16S rRNA (16S), and $28 \mathrm{~S}$ rRNA (28S) have in particular been used for taxonomic and phylogenetic studies. Several new species of Cirriformia and Timarete were described, including data on COI and 16S $[104,105]$. The Timarete punctata species complex was also revealed thanks to COI and $16 \mathrm{~S}$ data. Regarding these genera, it is important to note that the complete mitochondrial genomes of Timarete posteria and Cirriformia cf. tentaculata were made available $[288,289]$. The diversity of the bitentaculate Cirratulidae in North-East Atlantic was recently reviewed using the markers COI and $28 \mathrm{~S}$ with species delimitation analyses, revealing both cryptic diversity, and new species that presented distinct morphologies [93].

Currently, the majority of sequence data available for Paraonidae consists of partial sequences referred to two mitochondrial markers, COI and 16S, and one nuclear marker, $18 \mathrm{~S}$ rRNA (18S) [14]. Both mitochondrial markers turned out to be useful for species delimitation, but they are scarcely suitable for the resolution of deeper branches; 18S, instead, allows to disentangle phylogenetic relationships between different paraonid groups, but it is less useful to identify species, especially in the genus Aricidea, which seems to have radiated rather recently [14]. A fragment of the internal transcribed spacer 2 (ITS-2) represents a promising candidate as a nuclear gene that can be employed for species delimitation [290], but this fragment is highly variable, might be present in different copies, and sequences from somewhat distant species can be difficult to align, complicating subsequent analyses (see [291]). While universal primers are usually suitable for 16S, 28S, and 18S amplification, both COI and ITS- 2 show a variable amplification success across different genera and species and might need the design of customized primer pairs.

The few sequences of Cossuridae and Acrocirridae available for phylogenetic analyses include Histone H3, 28S, 16S, and COI, e.g., ref. [50]. Even fewer sequences are available for Longosomatidae, of COI and 18S, but the amplification of all these markers has proven relatively easy to amplify for both of these families.

More sequences are available for Sternaspidae, mainly of the mitochondrial markers COI and 16S, as well as a few sequences of the nuclear markers 28S, 18S, 5.8S, and Histone H3 [252].

\subsection{Internal Morphology}

Histological studies of cirratulids have been scarce and rarely used for systematic purposes, e.g., refs. [292,293]. While it might not be relevant for every single description, histology can provide useful information on the nature of some characters and how to describe some features such as the presence of an achaetous first segment in some bitentaculate cirratulids [94]. Histology also reveals details of reproductive biology, e.g., refs. [292,294], which can be another tool in species delimitation and important to make phylogenetic hypotheses. While confocal microscopy has been employed to study the internal morphology of acrocirrids and cossurids, it has yet to find an application in systematics [28,295]. Internal morphology of sternaspids has been studied using SEM, and TEM has been used to study the ultrastructure of sensory organs [31]. Confocal microscopical study of innervation of the branchial filament in Cossura pygodactylata suggested that the filament is homologous to branchiae of other polychaetes. Ultrastructural and confocal studies of the same cossurid species, including juvenile stages, revealed the nature of the anterior achaetous ring as a part of the prostomium, showed the origin of buccal tentacles from the soft axial pharynx, and illustrated some unique features such as the muscular system in the prostomium and an unusual heart body [296]. Micro-CT investigation of 
C. pygodactylata together with histological studies revealed details of internal anatomy, which can be useful for phylogenetic studies [295]. Micro-CT has not yet been used for other cirratuliform polychaetes.

\section{Conclusions}

The Acrocirridae, Cirratulidae, Cossuridae, Longosomatidae Paraonidae, and Sternaspidae are all examples of seemingly understudied groups of polychaetes, due to their rarity, difficulty to work with, or even a past lack of interest. However, more than 200 species have been described worldwide in the past 20 years, and significant progress has been made in understanding phylogenetic relationships to each other and to other annelid families with the advent of molecular phylogenetics and phylogenomics. Many species are still undescribed [297], and the distribution of many others, especially so-called cosmopolitan species, is still unknown. A continued interest in these groups and further integration of molecular data with more and more detailed morphological studies will be key to achieving these goals.

Author Contributions: Conceptualization and supervision, M.G., A.Z., J.L., D.F. and A.M.; methodology, writing — original draft preparation, review and editing and visualization M.G., A.Z., J.L., D.F. and A.M. All authors have read and agreed to the published version of the manuscript.

Funding: M.G. benefited from support by the Norwegian Taxonomy Initiative (http:/ / www.biodiversity. no/Pages/135523 (accessed on 5 March 2021) (Cryptic polychaetes in Norwegian waters, knr 49-13, pnr 70184228). A.Z. was supported by grants from the Russian Foundation of Basic Research (no. 18-05-60158 and 19-04-00501).

Data Availability Statement: Not applicable.

Acknowledgments: The authors would like to thank James Blake for discussion about Cirratuliade and collection methods, Julio Parapar for helpful discussions about Longosomatidae, and Leslie Harris for helpful discussion and advice on working with Cossuridae and staining methods. Thanks are also due to three anonymous reviewers who greatly improved the quality of this article. The first author is particularly grateful to Arne Nygren and Maria Capa for their support and the opportunity to write this article.

Conflicts of Interest: The authors declare no conflict of interest.

\section{References}

1. WoRMS-World Register of Marine Species. Available online: http://www.marinespecies.org/index.php (accessed on 10 March 2021).

2. Struck, T.H.; Golombek, A.; Weigert, A.; Franke, F.A.; Westheide, W.; Purschke, G.; Bleidorn, C.; Halanych, K.M. The Evolution of Annelids Reveals Two Adaptive Routes to the Interstitial Realm. Curr. Biol. 2015, 25, 1993-1999. [CrossRef] [PubMed]

3. Weigert, A.; Helm, C.; Meyer, M.; Nickel, B.; Arendt, D.; Hausdorf, B.; Santos, S.R.; Halanych, K.M.; Purschke, G.; Bleidorn, C.; et al. Illuminating the Base of the Annelid Tree Using Transcriptomics. Mol. Biol. Evol. 2014, 31, 1391-1401. [CrossRef]

4. Struck, T.H. Phylogeny. In Hanbook of Zoology, Annelida; Purschke, G., Böggemann, M., Westheide, W., Eds.; De Gruyter: Berlin, Germany; Boston, MA, USA, 2019; Volume 1: Annelida Basal Groups and Pleistoannelida, Sedentaria I; pp. 37-68.

5. Day, J.H. The polychaete fauna of South Africa. Part 8: New species and records from grab samples and dredgings. Bull. Br. Mus. (Nat. Hist.) Ser. Zool. 1963, 10, 381-445. [CrossRef]

6. Cerruti, A. Contributo all'anatomia, biologia e sistematica delle Paraonidae (Levinsenidae) con particolare riguardo alle specie del golfo di Napoli. Mittheilungen aus der Zoologischen Station zu Neapel 1909, 19, 459-512.

7. Caullery, M. Sur les Siboglinidae, type nouveau d'invertébrés receuillis par l'expédition du Siboga. Comptes Rendus Hebdomadaires des Séances de l'Académie des Sciences 1914, 158, 2014-2017.

8. Pizl, V.; Chalupský, J. Hrabeiella periglandulata gen. et sp. n. (Annelida) a curious worm from Czechoslowakia. Vestn. Cesk. Spol. Zool. 1984, 48, 291-295.

9. Ehrenberg, C.G. Animalia evertebrata exclusis Insectis. Series prima. In Symbolae Physicae, Seu Icones et Descriptiones Mammalium, Avium, Insectorum et Animalia Evertebra, Quae ex Itinere per Africam Borealem et Asiam Occidentalem Studio nova aut Illustrata Redierunt; Hemprich, F.G., Ehrenberg, C.G., Eds.; Officina Academica, ed.: Berlin, Germany, 1828; p. 126.

10. Lastochkin, D.A. New name [Potamodrilus] for the genus Stephensoniella. Ann. Mag. Nat. Hist. 1935, 16, 488. [CrossRef]

11. Malmgren, A.J. Annulata Polychaeta Spetsbergiæ, Grœnlandiæ, Islandiæ et Scandinaviæ. Öfversigt af Kongliga VetenskapsAkademien Förhandlingar 1867, 24, 127-235. 
12. Hartmann-Schröder, G. Annelida, Borstenwürmer, Polychaeta. In Die Tierwelt Deutschlands 58; Dahl, M., Peus, F., Eds.; Gustav Fischer: Jena, Germany, 1971; p. 594.

13. Struck, T.H.; Hessling, R.; Purschke, G. The phylogenetic position of the Aelosomatidae and Parergodrilidae, two enigmatic oligochaete-like taxa of the 'Polychaeta', based on molecular data from $18 S$ rDNA sequences. J. Zool. Syst. Evol. Res. 2002, 40, 155-163. [CrossRef]

14. Langeneck, J.; Barbieri, M.; Maltagliati, F.; Castelli, A. Molecular phylogeny of Paraonidae (Annelida). Mol. Phylogenet. Evol. 2019, 136, 1-13. [CrossRef] [PubMed]

15. Martínez, A.; Di Domenico, M.; Worsaae, K. Evolution of cave Axiokebuita and Speleobregma (Scalibregma, Annelida). Zool. Scr. 2013, 42, 623-636.

16. Li, Y.; Kocot, K.M.; Whelan, N.W.; Santos, S.R.; Waits, D.S.; Thornhill, D.J.; Halanych, K.M. Phylogenomics of tube worms (Siboglinidae, Annelida) and comparative performance of different reconstruction methods. Zool. Scr. 2017, 46, 200-213. [CrossRef]

17. Parapar, J.; Martínez, A.; Moreira, J. On the systematics and biodivesity of the Opheliidae and Scalibregmatidae. Diversity 2021, 13, 87. [CrossRef]

18. Hutchings, P.; Carrerette, O.; Nogueira, J.M.M.; Hourdez, S.; Lavesque, N. The Terebelliformia-Recent Developments and Future Directions. Diversity 2021, 13, 60. [CrossRef]

19. Worsaae, K.; Kerbl, A.; Di Domenico, M.; Gonzalez, B.C.; Bekkouche, N.; Martínez, A. Interstitial Annelida. Diversity 2021, 13 , 77. [CrossRef]

20. Martinsson, S.; Erséus, C. Cryptic Clitellata: Molecular Species Delimitation of Clitellate Worms (Annelida): An Overview. Diversity 2021, 13, 36. [CrossRef]

21. Meca, M.A.; Zhadan, A.E.; Struck, T.H. The Early Branching Group of Orbiniida Sensu Struck et al., 2015: Parergodrilidae and Orbiniidae. Diversity 2021, 13, 29. [CrossRef]

22. Banse, K. Acrocirridae n.fam. (Polychaeta Sedentaria). J. Fish. Res. Board Can. 1969, 26, 2595-2620. [CrossRef]

23. Ryckholt [Baron de], P. Mélanges paléontologiques, première partie. Mémoires Couronnés des Savants Étrangers de l'Académie Royale des Sciences, des Lettres et des Beaux Arts de Belgique 1851, 24, 1-176.

24. Carus, J.V. Vermes. In Handbuch der Zoologie; Kükenthal, W., Ed.; Wilhelm Engelmann: Leipzig, Germany, 1863; Volume 2, pp. $422-454$.

25. Hartman, O. Polychaetous annelids. Part 6. Paraonidae, Magelonidae, Longosomidae, Ctenodrilidae, and Sabellariidae. Allan Hancock Pac. Exped. 1944, 10, 311-389.

26. Saint Joseph [Baron de], A.A. Les annélides polychètes des côtes de Dinard. Troisième partie. Ann. des Sci. Nat. Zool. et Paléontol. 1894, 17, 1-395.

27. Hartman, O. Abyssal polychaetous annelids from the Mozambique Basin off southeast Africa, with a compendium of abyssal polychaetous annelids from world-wide areas. J. Fish. Res. Board Can. 1971, 28, 1407-1428. [CrossRef]

28. Martínez, A.; Worsaae, K.; Núñez, J. Acocirridae Banse, 1968. In Handbook of Zoology. Annelida; Westheide, W., Böggemann, M., Purschke, G., Eds.; De Gruyter: Berlin, Germany; Boston, MA, USA, 2019; Volume 1: Annelida Basal Groups and Pleistoannelida, Sedentaria I; pp. 422-439.

29. Blake, J.A.; Magalhães, W. Cirratulidae Ryckholt, 1851. In Handbook of Zoology. Annelida; Purschke, G., Westheide, W., Böggemann, M., Eds.; De Gruyter: Berlin, Germany; Boston, MA, USA, 2019; Volume 1: Annelida Basal Groups and Pleistoannelida, Sedentaria I; pp. 339-397.

30. Zhadan, A.E.; Salazar-Vallejo, S. Fauveliopsidae Hartman, 1971. In Hanbook of Zoology. Annelida; Purschke, G., Böggemann, M., Westheide, W., Eds.; De Gruyter: Berlin, Germany; Boston, MA, USA, 2019; Volume 1: Annelida Basal Groups and Pleistoannelida, Sedentaria I; pp. 317-328.

31. Fiege, D. Sternaspidae Carus, 1863. In Handbook of Zoology. Annelida; Purschke, G., Böggemann, M., Westheide, W., Eds.; De Gruyter: Berlin, Germany; Boston, MA, USA, 2019; Volume 1: Annelida Basal Groups and Pleistoannelida, Sedentaria I; pp. $440-457$.

32. Osborn, K.J.; Madin, L.P.; Rouse, G.W. The remarkable squidworm is an example of discoveries that await in deep-pelagic habitats. Biol. Lett. 2011, 7, 449-453. [CrossRef] [PubMed]

33. Salazar-Vallejo, S.I.; Carrera-Parra, L.F.; Fauchald, K. Phylogenetic affinities of the Flabelligeridae (Annelida, Polychaeta). J. Zool. Syst. Evol. Res. 2008, 46, 203-215. [CrossRef]

34. Ebbe, B.; Blake, J.A. Cossuridae Day, 1963. In Handbook of Zoology. Annelida; Purschke, G., Böggemann, M., Westheide, W., Eds.; De Gruyter: Berlin, Germany; Boston, MA, USA, 2019; Volume 1: Annelida Basal Groups and Pleistoannelida, Sedentaria I; pp. 309-317.

35. Blake, J.A. Paraonidae Cerruti 1909. In Handbook of Zoology. Annelida; Purschke, G., Böggemann, M., Westheide, W., Eds.; De Gruyter: Berlin, Germany; Boston, MA, USA, 2019; Volume 1: Annelida Basal Groups and Pleistoannelida, Sedentaria I; pp. 281-308.

36. Sousa, L.K.S.; Júnior, M.N.; Cutrim, M.V.J.; De Oliveira, V.M. Cossura yacy sp. Nov. (cossuridae, annelida) from a tropical brazilian estuary. Iheringia Ser. Zool. 2019, 109. [CrossRef]

37. Rouse, G.W.; Fauchald, K. Cladistics and polychaetes. Zool. Scr. 1997, 26, 139-204. [CrossRef] 
38. Zrzavý, J.; Říha, P.; Piálek, L.; Janouškovec, J. Phylogeny of Annelida (Lophotrochozoa): Total-evidence analysis of morphology and six genes. BMC Evol. Biol. 2009, 9, 189. [CrossRef]

39. Strelzov, V.E. Polychaete Worms of the Family Paraonidae Cerruti, 1909 (Polychaeta, Sedentaria); Akademia Nauk SSSR: Leningrad, Russia, 1973; pp. 1-169.

40. Bleidorn, C. The role of character loss in phylogenetic reconstruction as exemplified for the Annelida. J. Zool. Syst. Evol. Res. 2007, 45, 299-307. [CrossRef]

41. Rousset, V.; Pleijel, F.; Rouse, G.W.; Erséus, C.; Siddall, M.E. A molecular phylogeny of annelids. Cladistics 2007, 23, 41-63. [CrossRef]

42. Bleidorn, C. Phylogenetic relationships and evolution of Orbiniidae (Annelida, Polychaeta) based on molecular data. Zool. J. Linn. Soc. 2005, 144, 59-73. [CrossRef]

43. Blake, J.; Maciolek, N.J. Longosomatidae Hartman, 1944. In Handbook of Zoology. Annelida; Purschke, G., Böggemann, M., Westheide, W., Eds.; De Gruyter: Berlin, Germany; Boston, MA, USA, 2019; Volume 1: Annelida Basal Groups and Pleistoannelida, Sedentaria I; pp. 457-466.

44. Ehlers, E. Annulata nova vel minus cognita in Expeditione 'Porcupine' capta. Ann. Mag. Nat. Hist. 1874, 13, 292-298. [CrossRef]

45. Vijapure, T.; Sukumaran, S.; Manohar, C.S. Molecular characterization and phylogenetics of Indian polychaete fauna: Scope for implementation in ecological monitoring. Aquat. Ecol. 2019, 53, 665-677. [CrossRef]

46. Salazar-Vallejo, S.I.; Zhadan, A.E.; Rizzo, A.E. Revision of Fauveliopsidae Hartman, 1971 (Annelida, Sedentaria). Zootaxa 2019, 4637, 1-67. [CrossRef]

47. Grube, A.E. Die Familie der Cirratuliden. Jahres Bericht der Schlesischen Gesellschaft für Vaterländische Cultur Breslau 1873, 50, 59-66.

48. Grube, A.E. Die Familien der Anneliden. Arch. für Nat. Berl. 1850, 16, 249-364.

49. Gillet, P. Flabelligena amoureuxi new genus, new species (Polychaeta: Acrocirridae) from Crozet Islands (Indian Ocean). Bull. Mar. Sci. 2001, 68, 125-131.

50. Jimi, N.; Fujimoto, S.; Imura, S. A new interstitial genus and species of Acrocirridae from Okinawa-jima Island, Japan. Zoosymposia 2020, 19, 164-172. [CrossRef]

51. Hartman, O. Polychaeta from the Weddell Sea quadrant, Antarctica. Antarct. Res. Ser. 1978, 26, $125-223$.

52. Laubier, L. Chauvinelia biscayensis gen. sp. nov., un Flabelligeridae (annélide polychète sédentaire) aberrant de l'étage abyssal du Golfe de Gascogne. Bull. Soc. Zool. Fr. 1974, 99, 391-399.

53. Osborn, K.J.; Haddock, S.H.D.; Pleijel, F.; Madin, L.P.; Rouse, G.W. Deep-Sea, Swimming Worms with Luminescent “Bombs”. Science 2009, 325, 964. [CrossRef] [PubMed]

54. Salazar-Vallejo, S.; Gillet, P.; Carrera-Parra, L.F. Revision of Chauviniella, redescriptions of Flabelliseta incrusta, and Helmetophorus rankini, and their recognition as acrocirrids (Polychaeta: Acrocirridae). J. Mar. Biol. Assoc. U. K. 2007, 87, 465-477. [CrossRef]

55. Kudenov, J.D. Polychaeta from southeaster Australia 1. Acrocirridae Banse, 1969, from Victoria and New South Wales. Rec. Aust. Mus. 1976, 30, 137-151. [CrossRef]

56. Martínez, A.; Di Domenico, M.; Leasi, F.; Curini-Galletti, M.; Todaro, M.A.; Zotto, M.D.; Gobert, S.; Artois, T.; Norenburg, J.; Jörger, K.M.; et al. Patterns of diversity and endemism of soft-bodied meiofauna in an oceanic island, Lanzarote, Canary Islands. Mar. Biodivers. 2019, 49, 2033-2055. [CrossRef]

57. Osborn, K.J.; Rouse, G.W. Phylogenetics of Acrocirridae and Flabelligeridae (Cirratuliformia, Annelida). Zool. Scr. 2011, 40, 204-219. [CrossRef]

58. Hartman, O. Deep-Water Benthic Polychaetous Annelids off New England to Bermuda and Other North Atlantic Areas. Occas. Pap. Allan Hancock Found. 1965, 28, 1-378.

59. Gonzalez, B.C.; Borda, E.; Carbalho, R.; Schulze, A. Polychaetes from the Mayan underworld: Phylogeny, evolution, and cryptic diversity. Nat. Croat. Period. Musei Hist. Nat. Croat. 2012, 21, 51-53.

60. Nunez, J.; Ocana, O.; Brito, M.C. Two New Species (Polychaeta: Fauveliopsidae and Nerillidae) and other Polychaetes from the Marine Lagoon Cave of Jameos Del Agua, Lanzarote (Canary Islands). Bull. Mar. Sci. 1997, 60, 252-260.

61. Riera, R.; Monterroso, Ó.; Núñez, J.; Martínez, A. Distribution of meiofaunal abundances in a marine cave complex with secondary openings and freshwater filtrations. Mar. Biodivers. 2018, 48, 203-215. [CrossRef]

62. Hartman, O. Polychaetous annelids of the Indian Ocean including an account of species collected by members of the International Indian Ocean Expeditions, 1963-1964 and a catalogue and bibliography of the species from India. J. Mar. Biol. Assoc. India 1976, 16, 191-252.

63. Santos, P.J.P.; Silva, V.M.A.P. Macrochaeta westheidi n. sp.: First record of Acrocirridae for the Brazilian coast (annelida Polychaeta). Nerítica Curitiba 1993, 7, 7-12.

64. Magalhães, W.; Bailey-Brock, J.H. A new species of Acrocirrus (Polychaeta: Acrocirridae) from Coconut Island, Oahu, Hawaii. J. Mar. Biol. Assoc. U. K. 2012, 92, 1019-1102. [CrossRef]

65. Friedrich, H. Polychaetenstudien, I-III. Kiel. Meeresforsch. 1937, 1, 343-351.

66. Fauvel, P. Polychètes Sédentaires. Addenda aux Errantes, Archiannélides, Myzostomaires; Paul Chevalier: Paris, France, 1927; Volume 16, $494 \mathrm{p}$.

67. Westheide, W. Interstitielle Fauna von Galapagos. XXVI. Questidae, Cirratulidae, Acrocirridae, Ctenodrillidae (Polychaeta). Mikrofauna des Meeresbod. 1981, 82, 1-23. 
68. Parapar, J.; Moreira, J. Polychaeta of the 'DIVA-Artabria I' project (cruise 2002) in the continental shelf and upper slope off Galicia (NW Spain). Cah. de Biol. Mar. 2009, 50, 57-78.

69. Martínez, A.; Gonzalez, B.C. Volcaline anchialine habitats of Lanzarote. In Cave Ecology; Moldovan, O.T., Kováč, L., Halse, S., Eds.; Ecological Studies; Springer: Cham, Switzerland, 2018; Volume 235, pp. 399-414.

70. Martínez, A.; Kvindebjerg, K.; Lliffe, T.; Worsaae, K. Evolution of cave suspension feeding in Protodrilidae (Annelida). Zool. Scr. 2017, 46, 214-226. [CrossRef]

71. Worsaae, K.; Gonzalez, B.C.; Kerbl, A.; Holdfold Nielsen, S.; Terp Jørgensen, J.; Armenteros, M.; Iliffe, T.M.; Martínez, A. Diversity and evolution of the stygobitic Speleonerilla nom. nov. (Nerillidae, Annelida) with description of three new species from anchialine caves in the Caribbean and Lanzarote. Mar. Biodivers. 2019, 49, 2167-2192. [CrossRef]

72. Gonzalez, B.C.; Worsaae, K.; Fontaneto, D.; Martínez, A. Anophtalmia and elongation of body appendages in cave scale worms (Annelida: Aphroditiformia). Zool. Scr. 2018, 47, 106-121. [CrossRef]

73. Jumars, P.A.; Dorgan, K.M.; Lindsay, S.M. Diet of Worms Emended: An Update of Polychaete Feeding Guilds. Annu. Rev. Mar. Sci. 2015, 7, 497-520. [CrossRef]

74. Sars, M. Beskrivelser og Iagttagelser over nogle Moerkelige eller nye i Havet ved den Bergenske Kyst Levende Dyr af Polypernes, Acalephernes, Radiaternes, Annelidernes og Molluskernes Classer, med en kort Oversigt over de Hidtil af Forfatteren Sammesteds Fundne Arter og deres Forekommen; Thorstein Hallagers: Bergen, Norway, 1835; 81p.

75. Lamarck, J.B. Histoire Naturelle des Animaux sans Vertèbres, Préséntant les Caractères Généraux et Particuliers de ces Animaux, leur Distribution, leurs Classes, leurs Familles, leurs Genres, et la Citation des Principales Espèces qui s'y Rapportent; Précedés d'une Introduction Offrant la Determination des Caracteres Essentiels de l'Animal, sa Distinction du Vegetal et des Autres Corps Naturels, Enfin, l'Exposition des Principes Fondamentaux de la Zoologie; Deterville: Paris, France, 1818.

76. Hartman, O. Nomenclatural changes involving California polychaete worms. J. Wash. Acad. Sci. 1936, 26, 31-32.

77. Kinberg, J.G.H. Annulata Nova. Öfversigt af Königlich Vetenskapsakademiens Förhandlingar Stockholm 1866, 22, $239-258$.

78. Çinar, M.E.; Petersen, M.E. Re-description of Cirratulus dollfusi (Polychaeta: Cirratulidae), and Fauvelicirratulus as a new genus. J. Mar. Biol. Assoc. U. K. 2011, 91, 415-418. [CrossRef]

79. Czerniavski, V. Materialia ad zoographiam Ponticam comparatam. Bull. de la Société Impériale des Naturalistes de Moscou 1881, 56, 338-420.

80. Blake, J. Revision of some genera and species of Cirratulidae from the Western North Atlantic. Ophelia Suppl. 1991, 5, 17-30.

81. Chamberlin, R.V. The Annelida Polychaeta [Albatross Expeditions]. Mem. Mus. Comp. Zool. Harv. Coll. 1919, 48, 1-514.

82. Blake, J.A. Bitentaculate Cirratulidae (Annelida, Polychaeta) collected chiefly during cruises of the R/V Anton Bruun, USNS Eltanin, USCG Glacier, R/V Hero, RVIB Nathaniel B. Palmer, and R/V Polarstern from the Southern Ocean, Antarctica, and off Western South America. Zootaxa 2018, 4537, 1-130. [CrossRef]

83. Blake, J.A. Kirkegaardia (Polychaeta, Cirratulidae), new name for Monticellina Laubier, preoccupied in the Rhabdocoela, together with new records and descriptions of eight previously known and sixteen new species from the Atlantic, Pacific, and Southern Oceans. Zootaxa 2016, 4166, 1-93. [CrossRef] [PubMed]

84. Webster, H.E.; Benedict, J.E. The Annelida Chaetopoda from Eastport, Maine; Report of the United States Commissioner of Fisheries; U.S. Commission of Fish \& Fisheries: Washington, DC, USA, 1887; pp. 707-758.

85. Ørsted, A.S. Annulatorum Danicorum Conspectus. Auctore A.S. Örsted. Fasc. I. Maricolæ. (Quæstio ab Universitate Hafniensi ad Solvendum Proposita et Proemio Ornata); Sumtibus Librariæ Wahlianæ: Copenhagen, Denmark, 1843.

86. Claparède, A.R.E. Beobachtungen über Anatomie und Entwicklungsgeschichte Wirbelloser Thiere: An der Küste von Normandie Angestellt; W. Engelmann: Leipzig, Germany, 1863; p. 120, 118 plates.

87. Wilfert, M. Aphropharynx heterochaeta nov. gen. nov. spec., ein neuer polychaet aus der familie Ctenodrilidae Kennel 1882. Cah. de Biol. Mar. 1974, 15, 495-504.

88. Monticelli, F.S. Di un nuovo Ctenodrilide del Golfo di Napoli. Nota preliminare riassuntiva del socio ordinario. Rend. dell'Accad. delle Sci. Fische e Mat. 1910, 16, 61-64.

89. Hartman, O. Polychaetous annelids from California. Allan Hancock Pac. Exped. 1961, 25, 1-226.

90. Kennel, J. Über Ctenodrilus pardalis Clpd. Ein Beitrag zur Kenntniss der Anatomie und Knospung der Anneliden. Arb. aus dem Zool. Zootomischen Inst. Würzbg. 1882, 5, 373-429.

91. Magalhães, W.F.; Linse, K.; Wiklund, H. A new species of Raricirrus (Annelida: Cirratuliformia) from deep-water sunken wood off California. Zootaxa 2017, 4353, 51-68. [CrossRef] [PubMed]

92. Weidhase, M.; Bleidorn, C.; Simon, C.A. On the taxonomy and phylogeny of Ctenodrilus (Annelida: Cirratulidae) with a first report from South Africa. Mar. Biodivers. 2016, 46, 243-252. [CrossRef]

93. Grosse, M.; Bakken, T.; Nygren, A.; Kongsrud, J.A.; Capa, M. Species delimitation analyses of NE Atlantic Chaetozone (Annelida, Cirratulidae) reveals hidden diversity among a common and abundant marine annelid. Mol. Phylogenet. Evol. 2020, 149, 106852. [CrossRef]

94. Elias, R.; Rivero, M.S.; Orensanz, J.M.L. New species of Monticellina and Chaetozone (Polychaeta: Cirratulidae) in the SW Atlantic, and a review of Monticellina species. J. Mar. Biol. Assoc. U. K. 2017, 97, 1553-1563. [CrossRef]

95. Blake, J. Family Cirratulidae Ryckholdt, 1851. Including a revision of the Genera and Species from the Eastern North Pacific. In Taxonomic Atlas of the Benthic Fauna of the Santa Maria Bassin and Western Santa Barbara Channel; Blake, J., Hilbig, B., Scott, P.H., 
Eds.; Santa Barbara Museum of Natural History: Santa Barbara, CA, USA, 1996; Volume 6-The Annelida Part 3. Polychaeta: Orbiniidae to Cossuridae; pp. 27-70.

96. Magalhães, W.F.; Bailey-Brock, J.H.; Davenport, J.F. On the genus Raphidrilus Monticelli, 1910 (Polychaeta: Ctenodrilidae) with description of two new species. Zootaxa 2011, 2804, 1-14. [CrossRef]

97. Elías, R.; Rivero, M.S. Two new species of Cirratulidae (Annelida: Polychaeta) from Mar del Plata, Argentina (SW Atlantic). Zoosymposia 2009, 2, 139-148. [CrossRef]

98. Dean, H.K.; Blake, J. Monticellina (Polychaeta: Cirratulidae) from the Pacific coast of Costa ica with descriptions of six new species. Zoosymposia 2009, 2, 105-126. [CrossRef]

99. Blake, J.A.; Lavesque, N. A new species of Chaetozone (Polychaeta, Cirratulidae) from the Bay of Biscay offshore France, together with a review of Chaetozone species from the North Atlantic and adjacent waters. Zootaxa 2017, 4312, 565. [CrossRef]

100. Doner, S.A.; Blake, J.A. New species of Cirratulidae (Polychaeta) from the northeastern United States. Sci. Mar. 2006, 70, 65-73. [CrossRef]

101. Dean, H.K.; Blake, J.A. Ctenodrilidae Kennel, 1882. In Handbook of Zoology. Annelida; Westheide, W., Purschke, G., Böggemann, M., Eds.; De Gruyter: Berlin, Germany; Boston, MA, USA, 2019; Volume 1: Annelida Basal Groups and Pleistoannelida, Sedentaria I; pp. 328-338.

102. Blake, J.A. New species of Cirratulidae (Annelida, Polychaeta) from abyssal depths of the Clarion-Clipperton Fracture Zone, North Equatorial Pacific Ocean. Zootaxa 2019, 4629, 151-187. [CrossRef]

103. Magalhães, W.F.; Bailey-Brock, J.H. Bitentaculate Cirratulidae (Annelida: Polychaeta) from the northwestern Pacific Islands with description of nine new species. Zootaxa 2013, 3630, 80-116. [CrossRef]

104. Magalhães, W.F.; Seixas, V.C.; Paiva, P.C.; Elias, R. The Multitentaculate Cirratulidae of the Genera Cirriformia and Timarete (Annelida: Polychaeta) from Shallow Waters of Brazil. PLoS ONE 2014, 9, e112727. [CrossRef]

105. Choi, H.K.; Kim, H.; Yoon, S.M. Timarete posteria, a new cirratulid species from Korea (Annelida, Polychaeta, Cirratulidae). ZooKeys 2018, 806, 1-15. [CrossRef] [PubMed]

106. Blake, J.A.; Dean, H.K. New Species of Cirratulidae (Annelida, Polychaeta) from the Caribbean Sea. Zootaxa 2019, 4671, 301-338. [CrossRef]

107. Elías, R.; Saracho-Bottero, M.A.; Simon, C.A. Protocirrineris (Polychaeta:Cirratulidae) in South Africa and description of two new species. Rev. de Biol. Trop. 2019, 67, S70-S80. [CrossRef]

108. Elías, R.; Saracho-Bottero, M.A.; Magalhães, W.F. Two new species of Protocirrineris (Polychaeta: Cirratulidae) from Brazil. Rev. de Biol. Trop. 2019, 67, S81-S91. [CrossRef]

109. Schmidt, O. Zur Kenntnis der Turbellaria, Rhabdocoela und einiger anderer Wuermer des Mittelmeeres. Sitzungsberichte der Kaiserliche Akademie der Wissenschaften Wien Mathematisch Naturwissenschaftliche Klasse 1857, 23, 347-366.

110. Grube, A.E. Annulata Örstediana. Enumeratio Annulatorum, quae in itinere Indiam Occidentalem et Americam Centralem annis 1845-1848 suscepto legit cl. A.S. Oersted, adjectis speciebus nonnullis a cl. H. Kroyero in itinere ad Americam meridionalem collectis. Videnskabelige Meddelelser fra Dansk naturhistorisk Forening i Köbenhavn 1858, 3, 105-120.

111. Blake, J.A. New species of Chaetozone and Tharyx (Polychaeta: Cirratulidae) from the Alaskan and Canadian Arctic and the Northeastern Pacific, including a description of the lectotype of Chaetozone setosa Malmgren from Spitsbergen in the Norwegian Arctic. Zootaxa 2015, 3919, 501. [CrossRef]

112. Seixas, V.C.; Zanol, J.; Magalhães, W.F.; Paiva, P.C. Genetic diversity of Timarete punctata (Annelida: Cirratulidae): Detection of pseudo-cryptic species and a potential biological invader. Estuar. Coast. Shelf Sci. 2017, 197, 214-220. [CrossRef]

113. Westheide, W.; Haß-Cordes, E.; Krabusch, M. Ctenodrilus serratus (Polychaeta: Ctenodrilidae) is a truly amphi-Atlantic meiofauna species-Evidence from molecular data. Mar. Biol. 2003, 142, 637-642. [CrossRef]

114. Berkeley, E.; Berkeley, C. On a collection of Polychaeta from Southern California. Bull. South. Calif. Acad. Sci. 1941, 40, 16-60.

115. Omena, E.; Creed, J.C. Polychaete fauna of seagrass beds (Halodule wrightii Ascherson) along the coast of Rio de Janeiro (southeast Brazil). P. S. Z. N. Marine Ecology 2004, 25, 273-288. [CrossRef]

116. Çinar, M.E.; Ergen, Z. The presence of Chaetozone corona (Polychaeta: Cirratulidae) in the Mediterranean Sea: An alien or a native species? Cah. de Biol. Mar. 2007, 48, 339-346.

117. Le Garrec, V.; Grall, J.; Chevalier, C.; Guyonnet, B.; Jourde, J.; Lavesque, N.; Bonifácio, P.; Blake, J.A. Chaetozone corona (Polychaeta, Cirratulidae) in the Bay of Biscay: A new alien species for the North-east Atlantic waters? J. Mar. Biol. Assoc. U. K. 2017, 97, 433-445. [CrossRef]

118. Chambers, S.J. A redescription of Chaetozone setosa Malmgren, 1867 including a definition of the genus, and a description of a new species of Chaetozone (Polychaeta: Cirratulidae) from the Northeast Atlantic. Bull. Mar. Sci. 2000, 67, 10.

119. Langerhans, P. Die Wurmfauna von Madeira. III. Z. für Wiss. Zool. 1880, 34, 87-143.

120. Montagu, G. Description of several marine animals found on the south coast of Devonshire. Trans. Linn. Soc. Lond. 1808, 9 , 81-114. [CrossRef]

121. Berkeley, E.; Berkeley, C. Notes on the life-history of the polychaete Dodecaceria fewkesii (nom.n.). J. Fish. Res. Board Can. 1954, 11, 326-334. [CrossRef]

122. Dean, H.K. A new species of Raricirrus (Polychaeta: Ctenodrilidae) from wood collected in the Tongue of the Ocean, Virgin Islands. Proc. Biol. Soc. Wash. 1995, 108, 169-179. 
123. Hily, C. Spatio-temporal variability of Chaetozone setosa (Malmgren) populations on an organic gradient in the Bay of Brest, France. J. Exp. Marine Biol. Ecol. 1987, 112, 201-216. [CrossRef]

124. Petersen, M.E.; George, J.D. A new species of Raricirrus from Northern Europe, with notes on its biology and a discussion of the affinities of the genus (polychaeta: Ctenodrilidae). Ophelia Suppl. 1991, 5, 185-208.

125. Pearson, T.H.; Rosenberg, R. Macrobenthic succession in relation to organic enrichment and pollution of the marine environment Oceanogr. Mar. Biol. Annu. Rev. 1978, 16, 229-311.

126. Elías, R.; Rivero, M.S.; Palacios, J.R.; Vallarino, E.A. Sewage-induced disturbance on polychaetes inhabiting intertidal mussel beds of Brachidontes rodriguezii off Mar del Plata (SW Atlantic, Argentina). Sci. Mar. 2006, 70, 187-196. [CrossRef]

127. Elías, R.; Rivero, M.S.; Vallarino, E.A. Sewage impact on the composition and distribution of Polychaeta associated to intertidal mussel beds of the Mar del Plata rocky shore, Argentina. Iheringia Ser. Zool. 2003, 93, 309-318. [CrossRef]

128. Gibbs, P.; Langston, W.; Burt, G.; Pascoe, P. Tharyx marioni (Polychaeta): A remarkable accumulator of arsenic. J. Mar. Biol. Assoc. U. K. 1983, 63, 313-325. [CrossRef]

129. Milanovich, F.P.; Spies, R.; Guram, M.S.; Sykes, E.E. Uptake of copper by the polychaete Cirriformia spirabrancha in the presence of dissolved yellow organic matter of natural origin. Estuar. Coast. Mar. Sci. 1976, 4, 585-588. [CrossRef]

130. Moore, D.C. Raricirrus beryli Petersen and George (Ctenodrilidae): A new polychaete indicator species for hydrocarbon-polluted sediments. Ophelia Suppl. 1991, 5, 477-486.

131. Reish, D.J.; Gerlinger, T.V. A Review of the Toxicological Studies with Polychaetous Annelids. Bull. Mar. Sci. 1997, 60, 584-607.

132. Petersen, M.E. Reproduction and development in Cirratulidae (Annelida: Polychaeta). In Reproductive Strategies and Developmental Patterns in Annelids; Dorresteijn, A.W.C., Westheide, W., Eds.; Springer: Dordrecht, The Netherlands, 1999; pp. $107-128$.

133. Christie, G. A new species of Tharyx (Polychaeta: Cirratulidae) from the estuaries in north-east England. Sarsia 1984, 69, 69-73.

134. Hilbig, B. Family Cossuridae Day, 1963. In Taxonomic Atlas of the Benthic Fauna of the Santa Maria Basin and Western Santa Barbara Channel; Blake, J.A., Hilbig, B., Scott, P.H., Eds.; Santa Barbara Museum of Natural History: Santa Barbara, CA, USA, 1996; Volume 6-The Annelida Part 3. Polychaeta: Orbiniidae to Cossuridae; pp. 385-402.

135. Liñero-Arana, I.; Díaz-Díaz, Ó. A new species of Cossuridae (Annelida: Polychaeta) from Venezuela. Interciencia 2010, $35,789-792$.

136. Zhadan, A. Cossuridae (Annelida: Polychaeta: Sedentaria) from australian and adjacent waters: The first faunistic survey. Rec. Aust. Mus. 2015, 67, 1-24. [CrossRef]

137. Fournier, J.A.; Petersen, M.E. Cossura longocirrata: Redescription and distribution, with notes on reproductive biology and a comparison of described species of Cossura (Polychaeta: Cossuridae). Ophelia Suppl. 1991, 5, 63-80.

138. Read, G.B. Taxonomy and distribution of a new Cossura species (Annelida: Polychaeta: Cossuridae) from New Zealand. Proc. Biol. Soc. Wash. 2000, 113, 1096-1110.

139. Zhadan, A.E.; Vortsepneva, E.V.; Tsetlin, A.B. Redescription and biology of Cossura pygodactylata Jones, 1956 (Polychaeta: Cossuridae) in the White Sea. Invertebr. Zool. 2012, 9, 115-125. [CrossRef]

140. Reish, D.J. Description of a new species of Cossura (Annelida: Polychaeta) from the Mississippi Delta. J. Wash. Acad. Sci. 1958, $48,53-55$.

141. Bachelet, G.; Laubier, L. Morphology, ecology and juvenile development of Cossura pygodactylata Jones (Polychaeta, Cossuridae) in Arcachon Bay, SW France, with a reassessment of the geographical distribution of C. pygodactylata and C. soyeri Laubier. Mem. Mus. Natl. D'histoire Nat. 1994, 162, 355-369.

142. Ewing, R.M. Review of the genus Cossurella (Polychaeta: Cossuridae) including descriptions of two new species and a key to the species of the world. Bull. Biol. Soc. Wash. 1987, 7, 3-10.

143. Kitamori, R. Two new species of cirratulid and Nephthydidae (Annelida: Polychaeta. Bull. Jpn. Soc. Sci. Fish. 1960, 26, 1082-1085. [CrossRef]

144. Górska, B.; Gromisz, S.; Włodarska-Kowalczuk, M. Size assessment in polychaete worms-application of morphometric correlations for common North Atlantic taxa. Limnol. Oceanogr. Methods 2019, 17, 254-265. [CrossRef]

145. Zhadan, A. Two new species of Cossura (Cossuridae, Annelida) from the terminal lobes of the Congo River deep-sea fan. J. Mar. Biol. Assoc. U. K. 2017, 97, 881-888. [CrossRef]

146. Laubier, L. Découverte du genre Cossura (polychète, Cossuridae) en Méditerranée: Cossura soyeri sp. n. Vie et Milieu 1963, $14,833-842$.

147. Callier, M.D.; Fletcher, R.L.; Thorp, C.H.; Fichet, D. Macrofaunal community responses to marina-related pollution on the south coast of England and west coast of France. J. Mar. Biol. Assoc. U. K. 2009, 89, 19-29. [CrossRef]

148. Bogdanos, C.; Fredj, G. Sur la présence de Cossura coasta Kitamori, 1960 (Polychaeta, Cossuridae) dans les eaux cotieres Grecques (Mer Égée, Mer Ionienne). Thalassographica 1983, 6, 5-15.

149. Zenetos, A.; Gofas, S.; Verlaque, M.; Cinar, M.E.; Garcia Raso, J.E.; Bianchi, C.N.; Morri, C.; Azzurro, E.; Bilecenoglu, M.; Froglia, C.; et al. Alien species in the Mediterranean Sea by 2010. A contribution to the application of European Union's Marine Strategy Framework Directive (MSFD). Part I. Spatial distribution. Mediterr. Mar. Sci. 2010, 11, 381. [CrossRef]

150. Faulwetter, S.; Simboura, N.; Katsiaras, N.; Chatzigeorgiou, G.; Arvanitidis, C. Polychaetes of Greece: An updated and annotated checklist. Biodivers. Data J. 2017, 22, e20997. [CrossRef]

151. Raghunathan, C.; Gopi, K.C.; Chandra, K. Invasive alien faunal species in India. J. Gov. 2019, 18, 124-140.

152. Gaonkar, C.A.; Sawant, S.S.; Anil, A.C.; Venkat, K.; Harkantra, S.N. Mumbai harbour, India: Gateway for introduction of marine organisms. Environ. Monit. Assess. 2010, 163, 583-589. [CrossRef] [PubMed] 
153. Gutiérrez, D.; Gallardo, V.A.; Mayor, S.; Neira, C.; Vásquez, C.; Sellanes, J.; Rivas, M.; Soto, A.; Carrasco, F.; Baltazar, M. Effects of dissolved oxygen and fresh organic matter on the bioturbation potential of macrofauna in sublittoral sediments off Central Chile during the 1997/1998 El Niño. Mar. Ecol. Prog. Ser. 2000, 202, 81-99. [CrossRef]

154. Ryu, J.; Khim, J.S.; Kang, S.-G.; Kang, D.; Lee, C.-h.; Koh, C.-h. The impact of heavy metal pollution gradients in sediments on benthic macrofauna at population and community levels. Environ. Pollut. 2011, 159, 2622-2629. [CrossRef] [PubMed]

155. Moreira, J.; Lourido, A.; Troncoso, J.S. Temporal dynamics of the benthic assemblage in the muddy sediments of the harbour of Baiona (Galicia, NW Iberian Peninsula). Thalassas 2010, 26, 9-22.

156. Balachandar, K.; Sundaramanickam, A.; Kumaresan, S. Spatial and seasonal variation of macrobenthos from Puducherry Coast, Southeast Coast of India. Int. J. Curr. Microbiol. Appl. Sci. 2016, 5, 33-49. [CrossRef]

157. Chainho, P.; Chaves, M.L.; Costa, J.L.; Costa, M.J.; Dauer, D.M. Use of multimetric indices to classify estuaries with different hydromorphological characteristics and different levels of human pressure. Mar. Pollut. Bull. 2008, 56, 1128-1137. [CrossRef]

158. Khan, S.A.; Murugesan, P. Polychaete diversity in Indian estuaries. Indian J. Geo-Mar. Sci. 2005, 34, 114-119. [CrossRef]

159. Murugesan, P.; Ajmal Khan, S.; Ajithkumar, T.T. Temporal changes in the benthic community structure of the marine zone of Vellar estuary southeast coast of India. J. Mar. Biol. Assoc. India 2007, 49, 154-158.

160. Rakocinski, C.F.; Brown, S.S.; Gaston, G.R.; Heard, R.W.; Walker, W.W.; Summers, J.K. Macrobenthic responses to natural and contaminant-related gradients in northern Gulf of Mexico estuaries. Ecol. Appl. 1997, 7, 1278-1298. [CrossRef]

161. Méndez, N. Annelid assemblages in soft bottoms subjected to human impact in the Urías estuary (Sinaloa, Mexico). Oceanol. Acta 2002, 25, 139-147. [CrossRef]

162. Lohrer, A.M.; Chiaroni, L.D.; Hewitt, J.E.; Thrush, S.F. Biogenic Disturbance Determines Invasion Success In A Subtidal SoftSediment System. Ecology 2008, 89, 1299-1307. [CrossRef]

163. Widdicombe, S.; Austen, M.C. Mesocosm investigation into the effects of bioturbation on the diversity and structure of a subtidal macrobenthic community. Mar. Ecol. Prog. Ser. 1999, 189, 181-193. [CrossRef]

164. Rygg, B. Effect of sediment copper on benthic fauna. Mar. Ecol. Prog. Ser. 1985, 25, 83-89. [CrossRef]

165. Olsgard, F.; Hasle, J.R. Impact of waste from titanium mining on benthic fauna. J. Exp. Mar. Biol. Ecol. 1993, 172, 185-213. [CrossRef]

166. Burd, B.J. Evaluation of mine tailings effects on a benthic marine infaunal community over 29 years. Mar. Environ. Res. 2002, 53, 481-519. [CrossRef]

167. Ellis, D.V. The concept of "sustainable ecological succession"; and its value in assessing the recovery of sediment seabed biodiversity from environmental impact. Mar. Pollut. Bull. 2003, 46, 39-41. [CrossRef]

168. Ellis, D.V. Biodiversity reduction on contaminated sediments in the sea: Contamination or sediment mobility? Mar. Pollut. Bull. 2005, 50, 244-246. [CrossRef]

169. Lancellotti, D.A.; Stotz, W.B. Effects of shoreline discharge of iron mine tailings on a marine soft-bottom community in northern Chile. Mar. Pollut. Bull. 2004, 48, 303-312. [CrossRef]

170. Raman, A.V.; Ganapati, P.N. Pollution effects on ecobiology of benthic polychaetes in Visakhapatnam Harbour (Bay of Bengal). Mar. Pollut. Bull. 1983, 14, 46-52. [CrossRef]

171. Varadharajan, D.; Soundarapandian, P.; Gunalan, B.; Babu, R. Seasonal abundance of macro benthic composition and diversity along the south east coast of India. Eur. J. Appl. Sci. 2010, 2, 1-5.

172. Natesan, U.; Kalaivani, S.; Kalpana, G. Pollution assessment of Ennore (India) creek using macrobenthos. J. Environ. Geol. 2017, 1, 9-16. [CrossRef]

173. Shokat, P.; Nabavi, S.M.B.; Savari, A.; Kochanian, P. Ecological quality of Bahrekan coast, by using biotic indices and benthic communities. Transit. Waters Bull. 2010, 4, 25-34.

174. Grall, J.; Glémarec, M. Using biotic indices to estimate macrobenthic community perturbations in the Bay of Brest. Estuar. Coast. Shelf Sci. 1997, 44, 43-53. [CrossRef]

175. Borja, A.; Franco, J.; Pérez, V. A Marine Biotic Index to Establish the Ecological Quality of Soft-Bottom Benthos Within European Estuarine and Coastal Environments. Mar. Pollut. Bull. 2000, 40, 1100-1114. [CrossRef]

176. Teixeira, H.; Weisberg, S.B.; Borja, A.; Ranasinghe, J.A.; Cadien, D.B.; Velarde, R.G.; Lovell, L.L.; Pasko, D.; Phillips, C.A.; Montagne, D.E.; et al. Calibration and validation of the AZTI's Marine Biotic Index (AMBI) for Southern California marine bays. Ecol. Indic. 2012, 12, 84-95. [CrossRef]

177. Bigot, L.; Grémare, A.; Amoureux, J.-M.; Frouin, P.; Maire, O.; Gaertner, J.C. Assessment of the ecological quality status of soft-bottoms in Reunion Island (tropical Southwest Indian Ocean) using AZTI marine biotic indices. Mar. Pollut. Bull. 2008, 56, 704-722. [CrossRef] [PubMed]

178. Reish, D. Benthic Invertebrates as Indicators of Marine Pollution: 35 Years of Study. In Proceedings of the OCEANS'86, Washington, DC, USA, 23-25 September 1986; pp. 885-888. [CrossRef]

179. Reish, D.J. The relation of polychaetous Annelids to harbor pollution. Public Health Rep. 1955, 70, 1168-1174. [CrossRef]

180. Keeley, N.B.; Macleod, C.K.; Forrest, B.M. Combining best professional judgement and quantile regression splines to improve characterisation of macrofaunal responses to enrichment. Ecol. Indic. 2012, 12, 154-166. [CrossRef]

181. Blake, J.A. Life history analysis of five dominant infaunal polychaete species from the continental slope off North Carolina. J. Mar. Biol. Assoc. U. K. 1993, 73, 123-141. [CrossRef] 
182. Berkeley, E.; Berkeley, C. Some Further Records of Pelagic Polychaeta from the Northeast Pacific North Of Latitude $40^{\circ}$ N. and East of Longitude $175^{\circ}$ W., Together with Records of Siphonophora, Mollusca, and Tunicata from the Same Region. Can. J. Zool. 1960, 38, 787-799. [CrossRef]

183. Hartman, O. Endemism in the North Pacific Ocean, with emphasis on the distribution of marine annelids, and descriptions of new or little known species. In Essays in the Natural Sciences in Honor of Captain Allan Hancock on the Occasion of His Birthday July 26; Allan Hancock Foundation, Ed.; University of Southern California Press: Los Angeles, CA, USA, 1955; pp. 39-60.

184. Hartman, O. Polychaetous annelids collected by the USNS Eltanin and Staten Island cruises, chiefly from Antarctic Seas. Allan Hancock Monogr. Mar. Biol. 1967, 2, 1-387.

185. Parapar, J.; Vijapure, T.; Moreira, J.; Sukumaran, S. A new species of Heterospio (Annelida, Longosomatidae) from the Indian Ocean. Eur. J. Taxon. 2016. [CrossRef]

186. Blake, J.A. Family Paraonidae Cerruti 1909. In Taxonomic Atlas of the Benthic Fauna of the Santa Maria Basin and Western Santa Barbara Channel; 6-The Annelida Part 3. Polychaeta: Orbiniidae to Cossuridae; Blake, J.A., Hilbig, B., Scott, P.H., Eds.; Santa Barbara Museum of Natural History: Santa Barbara, CA, USA, 1996; pp. 27-70.

187. Hartley, J.P. The family Paraonidae (Polychaeta) in british waters: A new species and new records with a key to species. J. Mar. Biol. Assoc. U. K. 1981, 61, 133-149. [CrossRef]

188. Inajima, M. Paraonidae (Polychaeta) from Japan. Bull. Natl. Sci. Mus. Tokyo 1973, 16, 253-292.

189. Ranauro, N.; Barroso, R.; Paiva, P.C.; Nogueira, J.M.d.M. On the genus Sabidius Strelzov, 1973 (Annelida: Paraonidae), with a redescription of the type species and the description of a new species. PLoS ONE 2020, 15, e229717. [CrossRef]

190. Arriaga-Hernández, S.; Hernández-Alcántara, P.; Solís-Weiss, V. Description and distribution of two new species of Paraonidae (Annelida: Polychaeta) from a lagoon-estuarine ecosystem in the Southern Gulf of Mexico. Zootaxa 2013, 3686, 51-64. [CrossRef] [PubMed]

191. Zhou, L.; Reuscher, M.G. Description of a new species of Aricidea (Polychaeta: Paraonidae) from Chinese Seas. Proc. Biol. Soc. Wash. 2013, 126, 276-283. [CrossRef]

192. Erdoğan-Dereli, D.; Çinar, M.E.; Dağli, E. Cirrophorus species (Annelida: Polychaeta: Paraonidae) in the Sea of Marmara, with description of a new species. Zootaxa 2017, 4347, 137-150. [CrossRef] [PubMed]

193. Lovell, L. Paraonidae (Annelida: Polychaeta) Of The Andaman Sea, Thailand. Phuket Mar. Biol. Cent. Spec. Publ. 2002, 24, 33-56.

194. Aguirrezabalaga, F.; Gil, J. Paraonidae (Polychaeta) from the Capbreton Canyon (Bay of Biscay, NE Atlantic) with the description of eight new species. Sci. Mar. 2009, 73, 631-666. [CrossRef]

195. Langeneck, J.; Mazziotti, C.; Mikac, B.; Scirocco, T.; Castelli, A. Aricidea fragilis (Annelida: Paraonidae) in the Mediterranean Sea: Overlooked native or alien species? Eur. Zool. J. 2018, 85, 267-272. [CrossRef]

196. Castelli, A. Paraonidae (Annelida, Polychaeta) des fonds meubles infralittoraux des cotes toscanes. Cah. de Biol. Mar. 1985, 26, 267-279.

197. Laubier, L.; Ramos, J. Paraonidae (Polychètes Sédentaires) de Méditerranée. Bull. du Mus. Natl. d’Histoire Nat. Ser. 3 Zool. 1974, $168,1097-1148$.

198. Hartman, O. Orbiniidae, Apistobranchidae, Paraonidae and Longosomidae. Allan Hancock Pac. Exped. 1957, 15, $211-393$.

199. Katzmann, W.; Laubier, L. Paraonidae (Polychètes Sédentaires) de l'Adriatique. Ann. der Nat. Mus. Wien 1975, 79, 567-588.

200. Çinar, M.E.; Dagli, E.; Açik, S. Annelids (Polychaeta and Oligochaeta) from the Sea of Marmara, with descriptions of five new species. J. Nat. Hist. 2011, 45, 2105-2143. [CrossRef]

201. Langeneck, J.; Barbieri, M.; Maltagliati, F.; Castelli, A. A new species of Cirrophorus (Annelida: Paraonidae) from Mediterranean organically enriched coastal environments, with taxonomic notes on the family. J. Mar. Biol. Assoc. U. K. 2017, 97, 871-880. [CrossRef]

202. Mackie, A.S.Y. Paradoneis eliasoni sp. nov. (Polychaeta: Paraonidae) from northern European waters, with a redescription of Paradoneis lyra (Southern, 1914). Ophelia Suppl. 1991, 5, 147-155.

203. de Leon-Gonzáles, J.A.; Díaz-Castañeda, V. A new species of Paraonidae (Polychaeta: Paraonidae) from the western coast of Baja California, Mexico. Proc. Biol. Soc. Wash. 2011, 124, 40-44. [CrossRef]

204. López, E.; Sikorski, A. The Paraonidae (Annelida: Sedentaria) from Norway and adjacent seas, with two new species, four new records, and a redescription of Paraonides nordica Strelzov, 1968 based on type material. Zootaxa 2017, 4320, 41-67. [CrossRef]

205. Hobson, K.D. Two new species and two new records of the Family Paraonidae (Annelida, Polychaeta) from the northeastern Pacific Ocean. Proc. Biol. Soc. Wash. 1972, 85, 549-556.

206. Quintanar-Retama, O.; Hernández-Alcántara, P.; Solís-Weiss, V. Distribution patterns of three new species of Paradoneis (Annelida: Paraonidae) from the southern Gulf of Mexico, with a dichotomous key for the Grand Caribbean species. Mar. Biodivers. 2019, 49, 2851-2870. [CrossRef]

207. Laubier, L. Sur quelques Aricidea (Polychètes, Paraonidae) de Banyuls-sur-Mer. Vie et Milieu Ser. A 1967, 18, 99-132.

208. Jones, M.L. Paraonis pygoenigmatica new species, a new annelid from Massachusetts (Polychaeta: Paraonidae). Proc. Biol. Soc. Wash. 1968, 81, 323-334.

209. Mclelland, J.; Gaston, G. 2 New Species Of Cirrophorus (Polychaeta, Paraonidae) From The Northern Gulf of-Mexico. Proc. Biol. Soc. Wash. 1994, 107, 524-531.

210. Webster, H.E. The Annelida Chaetopoda of the Virginian coast. Trans. Albany Inst. 1879, 9, $202-269$. 
211. Grube, A.E. Über ein paar neue Anneliden aus der Familie der Spiodeen. Jahres Bericht der Schlesischen Gesellschaft für Vaterländische Cultur 1872, 50, 57-58.

212. McIntosh, W.C. On the Annelida obtained during the Cruise of H.M.S. 'Valorous' to Davis Strait in 1875. Trans. Linn. Soc. Lond. 1878, 1, 499-511. [CrossRef]

213. Tauber, P. Annulata Danica. En Kritisk Revision af de in Danmark Fundne Annulata Chaetognatha, Gephyrea, Balanoglossi, Discophoreae, Oligochaeta, Gymnocopa og Polychaeta; Reitzer: Kobenhavn, Denmark, 1879; p. 143.

214. Levinsen, G.M.R. Systematisk-geografisk Oversigt over de nordiske Annulata, Gephyrea, Chaetognathi og Balanoglossi. Videnskabelige Meddelelser fra den Naturhistoriske Forening i Kjöbenhavn 1884, 45, 92-350.

215. Ehlers, E. Die bodensässigen Anneliden aus den Sammlungen der deutschen Tiefsee-Expedition. In Wissenschaftlichte Ergebnisse der Deutschen Tiefsee-Expedition auf dem Dampfer 'Valdivia' 1898-1899; Chun, C., Ed.; Gustav Fischer: Jena, Germany, 1908; Volume 16, pp. 1-168.

216. Annenkova, N.P. Paraoniden der Meeren des Fernen Osten der USSR. Doklady Akademii Nauk SSSR 1934, 3, $656-658$.

217. Mesnil, F. Études de morphologie externe chez les Annélides. II. Remarques complémentaires sur les Spionidiens. La famille nouvelle des Disomidiens. La place des Aonides (sensu Tauber, Levinsen). Bull. Sci. Fr. Belg. 1897, 30, 83-100.

218. Brasier, M.J.; Wiklund, H.; Neal, L.; Jeffreys, R.; Linse, K.; Ruhl, H.; Glover, A.G. DNA barcoding uncovers cryptic diversity in $50 \%$ of deep-sea Antarctic polychaetes. R. Soc. Open Sci. 2016, 3, 160432. [CrossRef] [PubMed]

219. Hilbig, B.; Blake, J.A. Deep-sea polychaete communities in the northeast Pacific Ocean off the Gulf of the Farallones, California. Bull. Mar. Sci. 2006, 78, 243-269.

220. Reuscher, M.G. Biodiversity, Ecology, and Natural History of Polychaetous Annelids from the Gulf of Mexico. Ph.D. Thesis, Corpus Christi University, Corpus Christi, TX, USA, 2013.

221. Ribeiro, R.P.; Alves, P.R.; de Almeida, Z.d.S.; Ruta, C. A new species of Paraonis and an annotated checklist of polychaetes from mangroves of the Brazilian Amazon Coast (Annelida, Paraonidae). ZooKeys 2018, 1-34. [CrossRef]

222. Zhou, L.; Li, X.-Z. A report of the family Paraonidae (Annelida, Polychaeta) from China seas. Acta Zootaxon. Sin. 2007, 32, 275-282.

223. Lovell, L.L.; Fitzhugh, K. Taking a closer look: An SEM review of Levinsenia species (Polychaeta: Paraonidae) reported from California. Zootaxa 2020, 4751, 256-275. [CrossRef] [PubMed]

224. Langeneck, J.; Busoni, G.; Aliani, S.; Castelli, A. Deep-sea polychaetes (Annelida) from the Malta Escarpment (western Ionian Sea). Eur. Zool. J. 2017, 84, 142-152. [CrossRef]

225. Langeneck, J.; Lezzi, M.; Pasqua, M.D.; Musco, L.; Gambi, M.C.; Castelli, A.; Giangrande, A. Non-indigenous polychaetes along the coasts of Italy: A critical review. Mediterr. Mar. Sci. 2020, 21, 238-275.

226. Hartley, J.P. Cosmopolitan polychaete species: The status of Aricidea belgicae (Fauvel, 1936) and notes on the identity of A. suecica Eliason, 1920 (Polychaeta; Paraonidae). In Proceedings of the First International Polychaete Conference, Sydney, Australia, 4-9 July 1983; The Linnean Society of New South Wales: Sydney, Australia, 1984; pp. 7-20.

227. Erdoğan-Dereli, D.; Çinar, M.E. The diversity of the genus Aricidea (Polychaeta: Paraonidae) from the Sea of Marmara, with descriptions of two new species and two new records for the Mediterranean fauna. Zootaxa 2020, 4844, 1-73. [CrossRef]

228. Bakalem, A.; Gillet, P.; Pezy, J.-P.; Dauvin, J.-C. Inventory and the biogeographical affinities of Annelida Polychaeta in theAlgerian coastline (Western Mediterranean). Mediterr. Mar. Sci. 2020, 21, 157-182. [CrossRef]

229. Gibbs, P.E. Recent additions to the marine fauna of Whitstable, with a description of Aricidea minuta southward (Annelida: Polychaeta). Ann. Mag. Nat. Hist. 1965, 8, 33-36. [CrossRef]

230. Martín, D. La comunidad de Anélidos Poliquetos de las concreciones de algas calcáreas del litoral catalán. Caracterización de las especies. Publicaciones del Departamiento de Zoologia de Barcelona 1987, 13, 45-54.

231. Box, A.; Martin, D.; Deudero, S. Changes in seagrass polychaete assemblages after invasion by Caulerpa racemosa var. cylindracea (Chlorophyta: Caulerpales): Community structure, trophic guilds and taxonomic distinctness. Sci. Mar. 2010, 74, 317-329. [CrossRef]

232. Brito, M.C.; Martin, D.; Núñez, J. Polychaetes associated to a Cymodocea nodosa meadow in the Canary Islands: Assemblage structure, temporal variability and vertical distribution compared to other Mediterranean seagrass meadows. Mar. Biol. 2005, 146, 467-481. [CrossRef]

233. Çinar, M.E.; Dagli, E. Polychaetes (Annelida: Polychaeta) from the Aegean and Levantine coasts of Turkey, with descriptions of two new species. J. Nat. Hist. 2013, 47, 911-947. [CrossRef]

234. Langeneck, J.; Busoni, G.; Aliani, S.; Lardicci, C.; Castelli, A. Distribution and diversity of polychaetes along a bathyal escarpment in the western Mediterranean Sea. Deep Sea Res. Part I Oceanogr. Res. Pap. 2019, 144, 85-94. [CrossRef]

235. Lardicci, C.; Como, S.; Corti, S.; Rossi, F. Changes and recovery of macrozoobenthic communities after restoration measures of the Orbetello Lagoon (Tyrrhenian coast, Italy). Aquat. Conserv. Mar. Freshw. Ecosyst. 2001, 11, 281-287. [CrossRef]

236. Morri, C.; Castelli, A.; Diviacco, G.; Mori, M.; Bianchi, C.N. Zonazione di comunità bentiche lungo l'estuario della Magra (Mar Ligure). Atti Soc. Toscana Sci. Nat. Ser. B 1990, 97, 311-327.

237. Magalhães, W.F.; Bailey-Brock, J.H.; Barroso, R. A new species of Paradoneis Hartman, 1965 (Annelida: Paraonidae) from Hawaii with notes on its reproductive strategy. Mar. Biodivers. 2019, 49, 1617-1625. [CrossRef]

238. Gaston, G.R.; McLelland, J.A.; Heard, R.W. Feeding Biology, Distribution, and Ecology of Two Species of Benthic Polychaetes: Paraonis fulgens and Paraonis pygoenigmatica (Polychaeta: Paraonidae). Gulf Res. Rep. 1992, 8, 395-399. [CrossRef] 
239. Röder, H. Gangsysteme von Paraonis fulgens Levinsen 1883 (Polychaeta) in ökologischer, ethologischer und aktuopaläontologischer Sicht. Senckenbergiana Marit. 1971, 3, 3-51.

240. Blake, J.A.; Baptiste, E.M. Life history studies on dominant polychaete species from Georges Bank. In Georges Bank Benthic Infauna Monitoring Program, Final Report for Third Year of Sampling, U.S.; Maciolek-Blake, N., Grassle, J.F., Neff, J.M., Eds.; Department of the Interior, Minerals Management Service: Herndon, VA, USA, 1985; Chapter 6; pp. 140-178.

241. Levin, L.A.; Plaia, G.R.; Huggett, C.L. The influence of natural organic enhancement on life histories and community structure of bathyal polychaetes. In Reproduction, Larval biology and Recruitment of the Deep-Esa Benthos; Young, C.M., Eckelbarger, K.J., Eds.; Columbia University Press: New York, NY, USA, 1994; pp. 261-283.

242. López-Jamar, E.; O'Connor, B.; González, G. Demography and gametogenic cycle of Paradoneis armata Glémarec (Polychaeta, Paraonidae) in Ría de la Coruña, North-West Spain. Ophelia 1987, 27, 127-136. [CrossRef]

243. Giangrande, A. Polychaete reproductive patterns, life cycles and life histories: An overview. Oceanogr. Mar. Biol. Annu. Rev. 1997, 35, 323-386.

244. Sendall, K.; Salazar-Vallejo, S. Revision of Sternaspis Otto, 1821 (Polychaeta, Sternaspidae). ZooKeys 2013, 286, 1-74. [CrossRef]

245. Fiege, D. Sternaspidae Carus, 1863. In Handbook of Zoology Online. Annelida: Polychaetes; Westheide, W., Purschke, G., Eds.; De Gruyter: Berlin, Germany; Boston, MA, USA, 2016; Available online: https:/ /db.degruyter.com/view/Zoology/bp_029146-9_24 (accessed on 17 March 2021).

246. Salazar-Vallejo, S.I. Six New Tropical Sternaspid Species (Annelida, Sternaspidae) with Keys to Identify Genera and Species. Zool. Stud. 2017, 56. [CrossRef]

247. Fiege, D.; Barnich, R. A new genus and species of Sternaspidae (Annelida: Polychaeta) from the deep eastern Atlantic. Eur. J. Taxon. 2020, 699, 1-13. [CrossRef]

248. Stimpson, W. Synopsis of the marine Invertebrata of Grand Manan: Or the region about the mouth of the Bay of Fundy, New Brunswick. Smithson. Contrib. Knowl. 1853, 6, 28-37.

249. Petersen, M.E. Family Sternaspidae Carus, 1863. In Taxonomic Atlas of the Benthic Fauna of the Santa Maria Basin and Western Santa Barbara Channel; Volume 7-The Annelida Part 4. Polychaeta: Flabelligeridae to Sternaspidae; Blake, J.A., Hilbig, B., Scott, P.V., Eds.; Santa Barbara Museum of Natural History: Santa Barbara, CA, USA, 2000; pp. 331-336.

250. Otto, A.G. Animalium maritimorum, nondum editorum, genera duo. I. Sternaspis thalassemoides. Verhandlungen der Kaiserlichen Leopoldinisch Carolinischen Academie der Naturforscher 1821, 2, 619-627.

251. Sendall, K. Review and Revision of the Genus Sternaspis (Polychaeta: Sternaspidae) Using Cladistics on Morphological Characters. Master's Thesis, University of Victoria, Greater Victoria, BC, Canada, 2006.

252. Drennan, R.; Wiklund, H.; Rouse, G.W.; Georgieva, M.N.; Wu, X.; Kobayashi, G.; Yoshino, K.; Glover, A.G. Taxonomy and phylogeny of mud owls (Annelida: Sternaspidae), including a new synonymy and new records from the Southern Ocean, North East Atlantic Ocean and Pacific Ocean: Challenges in morphological delimitation. Mar. Biodivers. 2019, 49, 2659-2697. [CrossRef]

253. Méndez, N.; Yáñez-Rivera, B. Distribution and morphometry of the deep-sea sternaspids, Sternaspis maior, Sternaspis uschakovi, and Caulleryaspis fauchaldi (Polychaeta), in Mexican Pacific waters. Bull. Mar. Sci. 2015, 91, 457-467. [CrossRef]

254. Yoshino, K.; Nagayoshi, M.; Sato, M.; Katano, T.; Ito, Y.; Fuji, N.; Hamada, T.; Hayami, Y. Life history of Sternaspis costata (Sternaspidae: Polychaeta) in Ariake Bay, Japan. J. Mar. Biol. Assoc. U. K. 2016, 96, 647-655. [CrossRef]

255. Fiege, D.; Bütfering, B. SEM-Investigations on the morphology and anatomy of Sternaspis scutata (Ranzani, 1817) (Annelida: Polychaeta). In Proceedings of the 6th International Polychete Conference, Held at Curitiba, Paraná, Brazil, 2-7 August 1998. Bull. Mar. Sci. 2000, 67, 662-663.

256. Zhadan, A.E.; Tzetlin, A.B.; Salazar-Vallejo, S.I. Sternaspidae (Annelida, Sedentaria) from Vietnam with description of three new species and clarification of some morphological features. Zootaxa 2017, 4226, 75-92. [CrossRef] [PubMed]

257. Stimpson, W. Descriptions of new species of marine Invertebrata from Puget Sound, collected by the Naturalists of the North-west Boundary Commission, A.H. Campbell, Esq., Commissioner. Proc. Acad. Nat. Sci. Phila. 1864, 16, 153-161.

258. von Marenzeller, E. Südjapanische Anneliden I. Denkschriften der Kaiserlichen Akademie der Wissenschaften. Mathematisch Naturwissenschaftliche Classe 1879, 41, 109-154.

259. Kobayashi, G.; Mukai, R.; Alalykina, I.; Miura, T.; Kojima, S. Phylogeography of benthic invertebrates in deep waters: A case study of Sternaspis cf. williamsae (Annelida: Sternaspidae) from the northwestern Pacific Ocean. Deep Sea Res. Part II Top. Stud. Oceanogr. 2018, 154, 159-166. [CrossRef]

260. Salazar-Vallejo, S.; Buzhinskaja, G. Six new deep-water sternaspid species (Annelida, Sternaspidae) from the Pacific Ocean. ZooKeys 2013, 348, 1-27. [CrossRef] [PubMed]

261. Southern, R. Fauna of the Chilka Lake. Polychaeta of the Chilka Lake and also of fresh and brackish waters in other parts of India. Mem. Indian Mus. Calcutta 1921, 5, 563-693.

262. Salazar-Vallejo, S.I. Three new polar species of Sternaspis Otto, 1821 (Polychaeta: Sternaspidae). Zootaxa 2014, 3861, 333. [CrossRef]

263. Wu, X.; Salazar-Vallejo, S.; Xu, K. Two new species of Sternaspis Otto, 1821 (Polychaeta: Sternaspidae) from China seas. Zootaxa 2015, 4052, 373. [CrossRef]

264. Wu, X.; Xu, K. Diversity of Sternaspidae (Annelida: Terebellida) in the South China Sea, with descriptions of four new species. Zootaxa 2017, 4244, 403-415. [CrossRef]

265. Díaz-Díaz, O.; Rozbaczylo, N. Article Sternaspis chilensis n. sp., a new species from austral Chilean channels and fjords (Annelida, Sternaspidae). Zootaxa 2017, 4254, 269-276. [CrossRef] 
266. Salazar-Vallejo, S.I. Sternaspis piotrowskiae sp. nov. (Polychaeta: Sternaspidae) from the Philippine Islands. In The Coral Triangle: The 2011 Hearst Philippine Biodiversity Expedition; Williams, G.C., Terrence, M., Eds.; California Academy of Sciences: San Francisco, CA, USA, 2014; pp. 165-169.

267. Ranzani, C. Descrizione di una nova specie del genere Thalassema. Opusculi Sci. 1817, I, 112-116.

268. Wang, Z.; Liu, C.; Liu, H.; Xu, Z.; Wang, B.; Zheng, F. Complete mitochondrial genome of the Sternaspis scutata (Sternaspidae, Annelida). Mitochondrial DNA Part B 2019, 4, 1700-1701. [CrossRef]

269. Preetha Mini Jose, H.M.; Muthuvelu, S.; Sivaraj, S.; Murugesan, P. A note on the occurrence of Sternaspis scutata (Renier 1807)—A sternaspid polychaete from Sundarban Mangroves, West Bengal, India. J. Bombay Nat. Hist. Soc. 2014, 111, 62-64. [CrossRef]

270. Pillai, N.G.K. On some benthic polychaetes from Cochin estuary. J. Mar. Biol. Assoc. of India 2001, 43, 120-135.

271. Joydas, T.V.; Damodaran, R. Infaunal macrobenthos along the shelf waters of the west coast of India, Arabian Sea. Indian J. Mar. Sci. 2009, 38, 14 .

272. Abdelnaby, F.A. First record of Sternaspis scutata (Polychaeta, Sternaspidae) in Egyptian waters. Egypt. J. Aquat. Biol. Fish. 2020, 24, 317-326. [CrossRef]

273. Townsend, M.; Worsfold, T.M.; Smith, P.R.J.; Martina, L.J.; McNeill, C.L.; Kendall, M.A. Occurrence of Sternaspis scutata (Polychaeta: Sternaspidae) in the English Channel. Cah. Biol. Mar. 2006, 47, 281-285.

274. Wang, J.-B.; Li, X.-Z.; Wang, H.-F. Ecological characteristics of dominant polychaete species from the Jiaozhou Bay. Acta Zool. Sin. 2006, 52, 63-69.

275. Por, F.D. Lessepsian Migration. The influx of Red Sea Biota into the Mediterranean by Way of the Suez Canal; Springer: Berlin, Germany, 1978; p. 228.

276. Rietsch, M. Étude sur le Sternaspis scutata. Ann. des Sci. Nat. Sixieme Sér. Zool. 1882, 13, 1-84.

277. Fauchald, K.; Jumars, P.A. The Diet of Worms: A Study of Polychaete Feeding Guilds. Oceanogr. Mar. Biol. Annu. Rev. 1979, 17, 193-284.

278. Dales, R.P. The polychaete stomodeum and the inter-relationships of the families of Polychaeta. Proc. Zool. Soc. 1962, 39, 389-428. [CrossRef]

279. Dorgan, K.M.; D'Amelio, C.; Lindsay, S.M. Strategies of burrowing in soft muddy sediments by diverse polychaetes. Invertebr. Biol. 2016, 135, 287-301. [CrossRef]

280. Self, R.F.L.; Jumars, P.A. Cross-phyletic patterns of particle selection by deposit feeders. J. Mar. Res. 1988, 46, 119-143. [CrossRef]

281. Lim, H.S.; Hong, J.S. Distribution and growth pattern of Sternaspis scutata (Polychaeta: Sternaspidae) in Chinhae Bay, Korea. J. Korean Fish. Soc. 1996, 29, 537-545.

282. Ohwada, T. Mesh size for settlement and recruitment studies of polychaetes with reference to the effect of fixation on washing bottom samples. Asian Mar. Biol. 1988, 5, 35-40.

283. Blake, J.A.; Göransson, P. Redescription of Tharyx killariensis (Southern) from Ireland and description of two new species of Tharyx from the Kattegat, Sweden (Polychaeta, Cirratulidae). Zootaxa 2015, 4039, 501. [CrossRef] [PubMed]

284. Jägersten, G. Studies on the morpgology, larval development and biology of Protodrilus. Zool. Bidrag från Uppsala 1952, 29, 426-512.

285. Helm, C.; Capa, M. Comparative analyses of morphological characters in Sphaerodoridae and allies (Annelida) revealed by an integrative microscopical approach. Front. Mar. Sci. 2015, 1, 82. [CrossRef]

286. Surugiu, V.; Capa, M. The Occurrence of Amphiglena mediterranea (Leydig, 1851) (Annelida: Sabellidae) at the Romanian Coast of the Black Sea: A Case on an Unsuccessful Invasion? Russ. J. Biol. Invasions 2020, 11, 293-299. [CrossRef]

287. Nygren, A. Cryptic polychaete diversity: A review. Zool. Scr. 2014, 43, 172-183. [CrossRef]

288. Choi, H.K.; Kim, H.J.; An, Y.R.; Kim, H. The complete mitochondrial genome of Cirriformia cf. tentaculata (Polychaeta, Cirratulidae) from Dok-Do, Korea. Mitochondrial DNA B 2017, 2, 847-848.

289. Kim, H.; Min, G.-S.; Choi, H.K. The complete mitochondrial genome of Korean endemic species, Timarete posteria (Polychaeta, Cirratulidae). Mitochondrial DNA Part B 2019, 4, 501-502. [CrossRef]

290. Di Giuseppe, G.; Barbieri, M.; Vallesi, A.; Luporini, P.; Dini, F. Phylogeographical pattern of Euplotes nobilii, a protist ciliate with a bipolar biogeographical distribution. Mol. Ecol. 2013, 22, 4029-4037. [CrossRef] [PubMed]

291. Flot, J.-F.; Couloux, A.; Tillier, S. Haplowebs as a graphical tool for delimiting species: A revival of Doyle's "field for recombination" approach and its application to the coral genus Pocillopora in Clipperton. BMC Evol. Biol. 2010, 10, 372. [CrossRef] [PubMed]

292. Christie, G. A Comparative Study of the Reproductive Cycles of Three Northumberland Populations of Chaetozone Setosa (Polychaeta:Cirratulidae). J. Mar. Biol. Assoc. U. K. 1985, 65, 239-254. [CrossRef]

293. Day, J.H. A Monograph on the Polychaeta of Southern Africa. Part 2. Sedentaria; Trustees of the British Museum (Natural History): London, UK, 1967; p. 419.

294. Olive, P.J.W. Ovary structure and oogenesis in Cirratulus cirratus (Polychaeta: Cirratulidae). Mar. Biol. 1971, 8, 243-259. [CrossRef]

295. Parapar, J.; Zhadan, A.; Tzetlin, A.B.; Vortsepneva, E.V.; Moreira, J. Exploring the anatomy of Cossura pygodactylata Jones, 1956 (Annelida, Cossuridae) using micro-computed tomography, with special emphasis on gut architecture. Mar. Biodivers. 2018, 48, 751-761. [CrossRef] 
296. Zhadan, A.; Vortsepneva, E.; Tzetlin, A. Three-dimensional reconstruction of the musculature of Cossura pygodactylata Jones, 1956 (Annelida: Cossuridae). Zool. Anz. 2014, 253, 181-191. [CrossRef]

297. Pamungkas, J.; Glasby, C.J.; Read, G.B.; Wilson, S.P.; Costello, M.J. Progress and perspectives in the discovery of polychaete worms (Annelida) of the world. Helgol. Mar. Res. 2019, 73, 10. [CrossRef] 